\title{
Liquid Chromatography Analysis of Common Nutritional Components, in Feed and Food
}

\author{
Carolina Cortés-Herrera ${ }^{1}$, Graciela Artavia ${ }^{1}$, Astrid Leiva ${ }^{2}$ and Fabio Granados-Chinchilla ${ }^{2, *}$ (D) \\ 1 Centro Nacional de Ciencia y Tecnología de Alimentos (CITA), Universidad de Costa Rica, \\ Ciudad Universitaria Rodrigo Facio 11501-2060, Costa Rica; carolina.cortesherrera@ucr.ac.cr (C.C.-H.); \\ graciela.artavia@ucr.ac.cr (G.A.) \\ 2 Centro de Investigación en Nutrición Animal, Universidad de Costa Rica, Ciudad Universitaria Rodrigo 11501-2060, \\ Costa Rica; astrid.leiva@ucr.ac.cr \\ * Correspondence: fabio.granados@ucr.ac.cr; Tel.: +506-2511-2028; Fax: +506-2234-2415
}

Received: 14 September 2018; Accepted: 5 November 2018; Published: 20 December 2018

check for updates

\begin{abstract}
Food and feed laboratories share several similarities when facing the implementation of liquid-chromatographic analysis. Using the experience acquired over the years, through application chemistry in food and feed research, selected analytes of relevance for both areas were discussed. This review focused on the common obstacles and peculiarities that each analyte offers (during the sample treatment or the chromatographic separation) throughout the implementation of said methods. A brief description of the techniques which we considered to be more pertinent, commonly used to assay such analytes is provided, including approaches using commonly available detectors (especially in starter labs) as well as mass detection. This manuscript consists of three sections: feed analysis (as the start of the food chain); food destined for human consumption determinations (the end of the food chain); and finally, assays shared by either matrices or laboratories. Analytes discussed consist of both those considered undesirable substances, contaminants, additives, and those related to nutritional quality. Our review is comprised of the examination of polyphenols, capsaicinoids, theobromine and caffeine, cholesterol, mycotoxins, antibiotics, amino acids, triphenylmethane dyes, nitrates/nitrites, ethanol soluble carbohydrates/sugars, organic acids, carotenoids, hydro and liposoluble vitamins. All analytes are currently assayed in our laboratories.
\end{abstract}

Keywords: food and feed analysis; liquid chromatography; challenges; nutritional analysis; additives; contaminants

\section{Introduction}

Food and feed analysis are paramount to assess both nutritional quality and safety of commodities. Interconnectivity of food sources [1,2] and new processing techniques [3] make for a more diverse and complex food supply. Legal thresholds have been stipulated that establish acceptable levels for individual chemical additives, residues, and contaminants in products $[4,5]$. Feed is a paramount target for analysis since it situates at the start of the food chain and poor feed quality can affect the yield on food-producing animals [6]. Understanding the complexities of food safety is the goal of approaches such as One Health [7], Farm-to-Fork [6], or MyToolbox [8]. Furthermore, feed contaminants carryover downstream can reach products such as meat, eggs, and milk (see for example the transference of aflatoxin $\mathrm{M}_{1}$ from aflatoxin $\mathrm{B}_{1}$-contaminated feed). Ingredients either destined for food or feed production (e.g., cereals) are among the fundamental constituents for several staple commodities. Other regulations require food and feed labeling to list ingredients relating to the nutritional content $[9,10]$. All stakeholders involved in the food and feed chain must be able to 
assess product quality and safety. Hence, it is imperative to rely on techniques that meet several analytical performance parameters. More and more, food and feed analysis methods are based on LC (liquid-chromatography) [11,12], which has proven to be an optimal technology for screening, detection, and quantification of a vast variety of analytes (see Table 1). The reason behind this is related to the molecular affinity between the analyte and also: $i$. the mobile phase (which is usually a mixture of solvents) ii. stationary phase (modified silica and polymer scaffolds). Within the LC approach itself, several alternatives are available for a researcher to resolve a specific task at hand. Each analyte presents its own unique trials.

Table 1. Typical food and feed analytes assayed using HPLC (High-Performance Liquid-Chromatography).

\begin{tabular}{|c|c|}
\hline \multicolumn{2}{|r|}{ Additives } \\
\hline Analyte Category Examples & Relevance in Feed and Food Quality \\
\hline $\begin{array}{c}\text { Acidulants } \\
\text { Acetic acid, lactic acid, and citric acid [13]. }\end{array}$ & $\begin{array}{l}\text { Used in beverage, food, and feed production, are part of the primary metabolism, are often } \\
\text { produced by fermentation. Acidic additives serve as buffers to regulate acidity, antioxidants, } \\
\text { preservatives, flavor enhancers, and sequestrants. Related to beneficial effects on animal health and } \\
\text { growth performance as feed additives. }\end{array}$ \\
\hline $\begin{array}{l}\text { Antioxidants } \\
\text { Gallic, rosemarinic, canosic, and caffeic acids, } \\
\text { glabrene, procyanidins, quercetin, catechin } \alpha-, \beta-, \gamma-\text {-, } \\
\text { and } \delta \text {-tocopherols, Eugenol, Carnosine, Tyr-Phe-Glu, } \\
\text { and Tyr-Ser-Thr-Ala. }\end{array}$ & $\begin{array}{l}\text { Lipid and protein oxidation can impact meat quality, nutrition, safety, and organoleptic properties. } \\
\text { Antioxidants are added during animal production and meat processing to enhance the nutritional } \\
\text { and health benefits of meat and minimize the formation of carcinogens for the chemical safety of } \\
\text { cooked and processed meats }[14,15] \text {. They can also be used to extend food [16] and feed [17] shelf } \\
\text { life. }\end{array}$ \\
\hline $\begin{array}{l}\text { Preservatives } \\
\text { Acetates, bacteriocins, benzoates ( } p \text {-hydroxybenzoic } \\
\text { acid), borates, carbonates, lactates, nitrates/nitrites, } \\
\text { parabens, propionates, sorbates, and sulfites. }\end{array}$ & $\begin{array}{l}\text { Usually, act as bacteriostatic and bactericidal agents to prevent microbial spoilage, antimicrobials } \\
\text { not only extend shelf life, but they also enhance the product's safety [18]. }\end{array}$ \\
\hline $\begin{array}{l}\text { Flavors and fragrances } \\
\text { Alcohols, methyl ketones, 2,3-butanedione, lactone, } \\
\text { butanoic acid, esters, isovaleric acid, pyrazines, } \\
\text { geosmin, vanillin, benzaldehyde, terpenes. }\end{array}$ & $\begin{array}{l}\text { Widely used in food, beverage, feed, cosmetic, detergent, chemical and pharmaceutical formulations } \\
\text { [19]. }\end{array}$ \\
\hline $\begin{array}{l}\text { Sweeteners } \\
\text { Approved as food additives: saccharin, aspartame, } \\
\text { acesulfame potassium, sucralose, neotame, } \\
\text { advantame. Generally regarded as safe (GRAS): } \\
\text { Steviosides [28-31]. }\end{array}$ & $\begin{array}{l}\text { Non-nutritive sweeteners have become an essential part of daily life and are in increasing demand } \\
\text { as it is used in a wide variety of dietary and medicinal products [20]. They play a role in the } \\
\text { reduction of table sugar [21]. In the case of artificial sweeteners, their use is controversial as they } \\
\text { have associated with health risks }[20,22] \text { and water pollution [23]; currently, the use of natural } \\
\text { sweeteners is supported as an alternative [24]. Sweetened products must be subject to verification to } \\
\text { ensure the presence of the sweetener. Furthermore, sweeteners are regulated food additives [25] } \\
\text { unless recognized as safe [26,27]. }\end{array}$ \\
\hline \multicolumn{2}{|r|}{ Natural Components } \\
\hline Analyte Category Examples & Relevance in Feed and Food Quality \\
\hline $\begin{array}{l}\text { Inorganic ions } \\
\text { Sulfites, sulfates, phosphate, polyphosphate, nitrate } \\
\text { and nitrite, } N \text {-nitroso compounds, cyanide, bromide, } \\
\text { bromate, chloride, chlorite, fluoride, iodide. }\end{array}$ & $\begin{array}{l}\text { Essential in both raw and processed products, related to food nutritional quality, preservation, } \\
\text { technological processing, and safety [32]. }\end{array}$ \\
\hline $\begin{array}{l}\text { Lipids and fatty acids } \\
\mathrm{C}_{1: 0} \text { (formic/methanoic), } \mathrm{C}_{2: 0} \text { (acetic/ethanoic), } \mathrm{C}_{3: 0} \\
\text { (propionic/propanoic), } \mathrm{C}_{4: 0} \text { (butyric/butanoic), } \mathrm{C}_{6: 0} \\
\text { (caproic/hexanoic), } \mathrm{C}_{8: 0} \text { (caprylic/octanoic), } \mathrm{C}_{10: 0} \\
\text { (capric/decanoic), } \mathrm{C}_{12: 0} \text { (lauric/dodecanoic), } \mathrm{C}_{12: 0} \\
\text { (myristic/tetradecanoic), } \mathrm{C}_{16: 0} \\
\text { (palmitic/hexadecanoic), } 9 \mathrm{c}-\mathrm{C}_{16: 1} \\
\text { (palmitoleic/(9Z)-hexa-dec-9-enoic), stearic, oleic, } \\
\text { ricinoleic, vaccenic, linoleic, } \alpha \text {-linoleic, } \gamma \text {-linoleic, } \\
\text { arachidic, eicosapentaenoic, behenic, erucic, } \\
\text { docosahexaenoic, lignoceric, cholesterol [33-37]. }\end{array}$ & $\begin{array}{l}\text { Major constituents of foods and feeds, of dietary importance as a significant source of energy. } \\
\text { Provide essential fat-soluble nutrients. Are prone to peroxidation. Part of biological membranes. }\end{array}$ \\
\hline $\begin{array}{l}\text { Biogenic amines } \\
\text { Putrescine, histamine, cadaverine. }\end{array}$ & $\begin{array}{l}\text { Nitrogen-based toxic compounds, mainly formed through decarboxylation of amino acids. Relevant } \\
\text { for quality and safety of diverse foods such as dairy products [38], fermented goods [39] including } \\
\text { wines [40], fishery commodities [41]. }\end{array}$ \\
\hline $\begin{array}{l}\text { Amino acids } \\
\text { The main fermentative amino acids for animal } \\
\text { nutrition are L-lysine, L-threonine, and L-tryptophan. } \\
\text { DL-Methionine. }\end{array}$ & $\begin{array}{l}\text { Part of a protein-containing diet, and as supplemented individual products. Amino acids are used } \\
\text { in medical (parenteral) nutrition and dietary supplements [42]. }\end{array}$ \\
\hline $\begin{array}{l}\text { Carbohydrates } \\
\text { Glucose is the primary energy source for fetal growth, } \\
\text { and lactose is crucial for the development of human } \\
\text { and animal infants alike. }\end{array}$ & The most abundant feed energy in diets for some species of animals $[43,44]$. \\
\hline $\begin{array}{l}\text { Vitamins } \\
\text { Fat-soluble: retinol (retinol (vitamin } A \text { ) and retinyl } \\
\text { acetate, and palmitate), tocopherols ( } \alpha \text { - (vitamin } E) \text {, } \\
\beta-, \gamma-\text {, and } \delta \text { - and their acetates), ergocalciferol } \\
\left.\left.\text { (vitamin } D_{2}\right) \text {, cholecalciferol (vitamin } D_{3}\right), \\
\left.\text { phylloquinone (vitamin } K_{1}\right) \text {, menaquinone (vitamin } \\
\left.\mathrm{K}_{2}\right), 7 \text {-dehydrocholesterol, } \beta \text {-carotene. Hydrosoluble } \\
\text { or B complex vitamins: thiamine }\left(B_{1}\right) \text {, Riboflavin }\left(B_{2}\right) \text {, } \\
\text { flavin mononucleotide or riboflavin- } 5^{\prime} \text {-phosphate, } \\
\text { niacin/nicotinamide riboside/niacinamide }\left(B_{3}\right) \text {, } \\
\text { pantothenic acid }\left(B_{5}\right) \text {, } \\
\text { pyridoxine/pyridoxamine/pyridoxal }\left(B_{6}\right) \text {, biotin }\left(B_{7}\right) \text {, } \\
\text { folates }\left(B_{9}\right) \text {, cobalamines }\left(B_{12}\right)[45] \text {. }\end{array}$ & $\begin{array}{l}\text { Complex unrelated compounds present in minute amounts in natural foodstuffs. Essential to } \\
\text { normal metabolism; their deficiency causes disease. }\end{array}$ \\
\hline
\end{tabular}


Table 1. Cont.

\begin{tabular}{|c|c|}
\hline \multicolumn{2}{|r|}{ Additives } \\
\hline Analyte Category Examples & Relevance in Feed and Food Quality \\
\hline $\begin{array}{l}\text { Alkaloids } \\
\text { Octopamine, synephrine, tyramine, } \\
N \text {-methyl-tyramine, hordenine in bitter orange } \\
\text { products [47], morphine, codeine, thebaine, } \\
\text { papaverine, and noscapine in poppy straw [48], } \\
\text { caffeine and trigonelline in coffee [49], indole and } \\
\text { oxindole alkaloids in Uncaria sp. [50], theobromine } \\
\text { and caffeine in tea [51] and coffee [52], Harman } \\
\text { alkaloids (harmane and harmine) in passion fruit [53], } \\
\text { ergot alkaloids in animal feed (ergometrine, } \\
\text { ergotamine, ergocornine, ergocryptine, ergocristine } \\
\text { [54], piperine [55]. }\end{array}$ & $\begin{array}{l}\text { Alkaloids are natural compounds with a characteristic cyclic structure and a nitrogen atom [46]. } \\
\text { Alkaloid-containing plants are an essential part of the regular diet, present as natural constituents of } \\
\text { several food products [46]. The most common use for alkaloid-containing plants is as stimulants } \\
\text { increased concentrations of these compounds can be attained within the food chain as a result of } \\
\text { food processing, as food contaminants or as food flavorings [46]. }\end{array}$ \\
\hline \multicolumn{2}{|r|}{ Residues and Contaminants } \\
\hline Analyte Category Examples & Relevance in Feed and Food Quality \\
\hline $\begin{array}{l}\text { Chemotherapeutics and antiparasitic drugs } \\
\text { Tetracyclines [56]. }\end{array}$ & $\begin{array}{l}\text { Antibiotics are extensively utilized in productive animals with therapeutic, prophylactic, } \\
\text { metaphylactic, growth promoting, and food effectiveness enhancing ends. These practices that have } \\
\text { been reflected in veterinary residues in products for human consumption (meat, eggs, and milk) and } \\
\text { is also related to directly with allergies and antimicrobial resistance. }\end{array}$ \\
\hline Aflatoxins [58]. & $\begin{array}{l}\text { Mycotoxins are practically ubiquitous contaminants, classified as teratogenic, carcinogenic and } \\
\text { immunosuppressive, and that affects a great variety of grains, fruits and seeds, as well as eggs, dairy } \\
\text { products, compounds feeds, and other feed ingredients [57]. }\end{array}$ \\
\hline $\begin{array}{l}\text { Pesticides } \\
\text { Atrazine, glyphosate, aminomethylphosphonic acid, } \\
\text { phenoxy herbicides. }\end{array}$ & $\begin{array}{l}\text { Used for crop protection and to treat infestations in livestock. Their poor use results in } \\
\text { contamination of the environment and the food itself, impacting human health. Residues usually } \\
\text { found in vegetables, fruits, honey, fish, eggs, milk, and meat, serving as potential sources of } \\
\text { contamination to consumers [59-61]. }\end{array}$ \\
\hline
\end{tabular}

To successfully analyze or isolate a compound, a researcher is faced with several questions: What is the problem to solve, the objective or purpose for the analysis? Is the required data qualitative or quantitative? Are there two or multiple compounds to be separated? What are the physicochemical characteristics of the target(s)? What matrix was the analyte recovered from and which interferences are expected? What is the amount of analyte expected to be recovered? What equipment is accessible in the laboratory?

Considering the above, a suitable column (Table 2) and detection system must be selected (Table 3). Sample preparation can aid to solve some of these issues, especially those regarding interferences and sensitivity but cannot solve issues with poor detector choice. For example, if sensitivity is a problem using the selected detection system on hand and no other system is available, the initial sample mass can be increased, or a concentration step (evaporation or solid phase extraction (SPE)) can be performed. Additionally, the sample injection volume can be expanded to improve sensitivity.

Table 2. General conditions required for each mode of chromatography.

\begin{tabular}{|c|c|c|c|c|c|c|}
\hline $\begin{array}{l}\text { Type of Liquid } \\
\text { Chromatography }\end{array}$ & Micro & Semi-Micro & Conventional & Semi-Preparative & Preparative & Process \\
\hline Column internal diameter, $\mathrm{mm}$ & $0.3<x \leq 1.0$ & $1.0<x \leq 3.0$ & $4.0<x \leq 8.0$ & $8.0<x \leq 20.0$ & $20.0<x \leq 50.0$ & $x>50.0$ \\
\hline Eluent flow rate, $\mathrm{mL} \min ^{-1}$ & $0.001<x \leq 0.1$ & $0.1<x \leq 0.4$ & $0.4<x \leq 2.0$ & $2.0<x \leq 10.0$ & $10.0<x \leq 150.0$ & $x>150.0$ \\
\hline
\end{tabular}

Additionally, automation is relevant for conserving resources and reducing turnover times. An analyst can program an autosampler to increasingly adjust the volume of a standard with a fixed concentration. For example, to construct a calibration curve between 1000 and $62.5 \mu \mathrm{g} \mathrm{L}^{-1}$, one could use a $1000 \mu \mathrm{g} \mathrm{L}^{-1}$ standard and instruct the sampler to take from the same vial $20 \mu \mathrm{L}, 10 \mu \mathrm{L}, 5 \mu \mathrm{L}, 2.5 \mu \mathrm{L}$, $1.25 \mu \mathrm{L}$, consecutively. The sampler will construct a calibration curve without analyst intervention and this automation will reduce errors. Autosamplers are designed to inject small volumes without significant loss, with good precision, and adequate reproducibility. They can also inject variable amounts, dilute the sample prior to injection and perform precolumn derivatization [91]. If a sample is outside of calibration standard of higher concentration, an analyst can inject a different volume to ensure it will fit among the calibration curve range. However, injection volume has an impact on peak shape. The method must be validated to show this is a valid approach. (See for example, [92]). Reference for one example of the versatility of an LC system and capabilities for its automation. In this review, we intend to give the reader a thorough background on the common analyses performed, for quality assurance and safety, in food and feed laboratories. We will include the most recent and 
relevant experience gathered for each test while pointing out the difficulties that each essay presents and the common ground shared by both types of laboratories.

Table 3. Characteristics of the most common detectors used in liquid chromatography.

\begin{tabular}{|c|c|}
\hline $\begin{array}{c}\text { Detector Type Range of Applications, Attributes, and Minimal } \\
\text { Detectable Quantity Limitations }\end{array}$ & Applications in Feed and Food Quality \\
\hline \multicolumn{2}{|c|}{ Non-Destructive Detectors } \\
\hline $\begin{array}{l}\text { Photodiode-Array (PDA)/Variable wavelength (VW)/UV-vis } \\
\text { Selective; universal at low wavelengths, 3D spectra comparison can } \\
\text { determine peak purity, can detect nanograms. } \\
\text { Chromophore must be presesent, solvents transparent to the wavelength } \\
\text { used must be provided. }\end{array}$ & $\begin{array}{l}\text { Sulfonated azo dyes in beverages, hard candy and fish roe samples [62], purity of } \\
\text { caffeine reference material [63], sulfamethazine and trimethoprim in liquid feed } \\
\text { premixes [64], nitrofurans animal feed [65]. }\end{array}$ \\
\hline $\begin{array}{l}\text { Fluorescence (FL) } \\
\text { Very selective and specific; monitors two wavelengths simultaneously, 3D } \\
\text { fluorescent spectra, fluorescent fingerprinting/fluorescence pattern analysis } \\
\text { [66] gradients do not affect baseline significantly, can detect low picograms. } \\
\text { Fluorophore must be present, derivative formation and quenching are } \\
\text { often needed. }\end{array}$ & $\begin{array}{l}\text { Sulfonamides [67] and fluoroquinolones [68] in animal feed, aflatoxins in agricultural } \\
\text { food crops [69] and milk [70]. }\end{array}$ \\
\hline $\begin{array}{l}\text { Electrochemical (EC) } \\
\text { Very selective; oxidation or reduction must be possible, can detect from } \\
\text { femtograms to nanograms. } \\
\text { Conductive mobile phase, susceptible to background noise and } \\
\text { electrode degradation. }\end{array}$ & Macrolide antibiotics in animal feeds [71], vitamin C in oranges and apples [72]. \\
\hline $\begin{array}{l}\text { Refractive index (RI) } \\
\text { Universal (All compounds affect refractive properties) and versatile; solvent } \\
\text { compatible, relatively simple, can detect micrograms. } \\
\text { Gradient incompatible, high S/N ratio when the pump is mixing two or } \\
\text { more solvents, susceptible to temperature and flow variation. }\end{array}$ & Inulin in chicory roots [73], total carbohydrates in wine and wine-like beverages [74]. \\
\hline $\begin{array}{l}\text { Conductivity } \\
\text { Selective; an ionic form of compound necessary can detect low pictograms. } \\
\text { Suppression of mobile phase background conductivity, special } \\
\text { equipment required. }\end{array}$ & $\begin{array}{l}\text { Choline, and trimethylamine in feed additives [75], L-carnitine, choline, and metal } \\
\text { ions in infant formula [76]. }\end{array}$ \\
\hline \multicolumn{2}{|c|}{ Destructive Detectors } \\
\hline $\begin{array}{l}\text { Mass spectrometry } \\
\text { Selective and specific; based on a specified mass/charge ratio, ion } \\
\text { fractionation, can detect low nanograms. Expensive, expert users are } \\
\text { needed for equipment and data manipulation. }\end{array}$ & $\begin{array}{l}\text { Analysis of acrylamide in food [77], tiamulin, trimethoprim, tylosin, sulfadiazine, } \\
\text { and sulfamethazine residues in medicated feed [78], multiclass antibiotics in eggs } \\
\text { [79], zearalenone and deoxynivalenol metabolites in milk [80], cattle feed analysis of } \\
\text { Aspergillus clavatus mycotoxins [81], choline chloride in feed and feed premixes [82]. }\end{array}$ \\
\hline $\begin{array}{l}\text { Radioactivity } \\
\text { Selective; Distribution and mass balance wide response range can } \\
\text { detect pictograms. } \\
\text { Large-volume flow cells can produce peak broadening and decreased } \\
\text { the resolution. }\end{array}$ & Drug metabolite identification [83]. \\
\hline $\begin{array}{l}\text { Evaporative light scattering (ELS) } \\
\text { Universal; Nonvolatile analyte nebulization, can detect in the range } \\
\text { of nanograms. } \\
\text { Volatile buffers required, poor reproducibility and limited dynamic range. }\end{array}$ & $\begin{array}{l}\mathrm{N} \text {-acetylglucosamine and } \mathrm{N} \text {-acetylgalactosamine in dairy foods [84], sucralose and } \\
\text { related compounds [85], spectinomycin and associated substances [86]. }\end{array}$ \\
\hline $\begin{array}{l}\text { Corona-Charged aerosol [87] } \\
\text { Universal; can detect non-ultraviolet and weakly ultraviolet active } \\
\text { compounds [88], ionized particles measured by an electrometer, can detect } \\
\text { low nanograms. } \\
\text { Volatile buffers required. }\end{array}$ & $\begin{array}{l}\text { Erythritol, xylitol, sorbitol, mannitol, maltitol, fructose, glucose, sucrose, and maltose } \\
\text { in food products [89], fumonisins in maize [90]. }\end{array}$ \\
\hline
\end{tabular}

\section{Measurements of Commonly Consumed Food Commodities}

\subsection{Polyphenols}

Polyphenols usually refers to several chemical compounds including flavanols (e.g., catechins and tannins from tea), flavanones (i.e., hesperidin from citrus fruits), flavonols (e.g., quercetin from tea, apples and onions), "chlorogenic acids" (including hydroxycinnamic acids caffeic, ferulic, $p$-coumarinic acids usually extracted from coffee), anthocyanins (which are partly responsible for imparting color to plant structures), and stilbenes (e.g., from berries, grape skins and peanuts) (Figure 1) [93].

These compounds, secondary metabolites from plants [94], have, among other functions, a protective capability within the vegetable tissue, structure, and support [94], and, even, pollinator attraction [95]. For example, chlorogenic acid (i.e., the esterification product between caffeic and quinic acid) is an intermediate in lignin biosynthesis [96]. Data suggests that long-term consumption of such compounds can have beneficial effects [94] as it can improve an organism's antioxidant capacity [93] which in turn relates, for example, to cognitive improvement [97] and reduction in adipogenesis and oxidative stress [98]. Fruits, especially berries, are [97-101] rich in these bioactive compounds, both extractable [102,103] and non-extractable [104]. From the technological standpoint, polyphenol safeguard is paramount to achieve functional foods [105] with added value 
(e.g., beverages) and a bioactive capacity of compounds as close as those from the raw material. Several operation units have been applied to fruits to assess polyphenol retention after processing including nanofiltration [101], high hydrostatic pressure [106], and drying [107,108]. Method-wise, the solvent has a profound effect on the number and type of polyphenols extracted. Polyphenol analysis must first identify the type of matrix to be analyzed, the chemical nature of the polyphenols of interest, and different solvents and solvent systems should be examined. The most appropriate solvent for the case in hand (i.e., maximizing compound diversity and yield) should be the one selected [109]. For example, Flores and coworkers resuspended the methanolic extract in hexane, chloroform, ethyl acetate, and $n$-butanol and reanalyzed each fraction. Ethyl acetate fraction exhibited the best results [110]. Finally, though polyphenols are usually related to health applications [111,112], antinutritional effects should be considered [109]. Some examples of polyphenol analysis are included in Table 4.

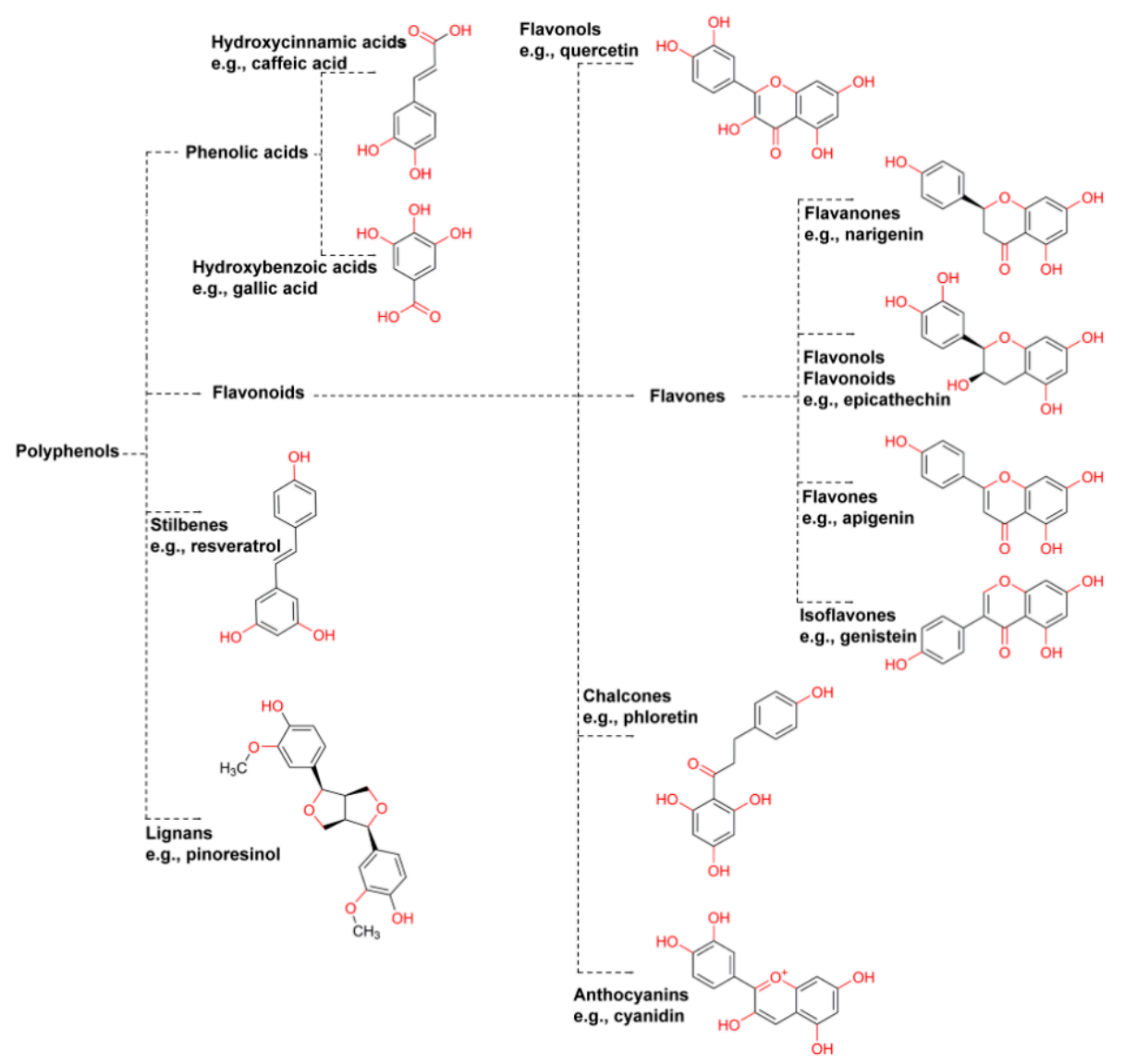

Figure 1. Polyphenols structure and classification [97]. Highly functionalized structures account for the molecules radical scavenging, metal ion chelating, and enzyme inhibition. Hydrogen bonding can stabilize phenoxyl radicals. 
Table 4. Polyphenol analysis in different matrices, based on liquid chromatography, and varied approaches to determine them.

\begin{tabular}{|c|c|c|c|c|}
\hline Matrix & Analytes Identified & Extraction Method & Measurement Method, Chromatographic Column & Reference \\
\hline Berries & $\begin{array}{l}\text { Anthocyanins }(68.6 \%) \\
\text { hydroxycinnamic acids }(23.9 \%) \text {, } \\
\text { flavonols }(4.4 \%)\end{array}$ & $\mathrm{H}_{2} \mathrm{O}$, membrane ultrafiltration & $\begin{array}{l}\text { Preparative LC: } 250 \times 20 \mathrm{~mm} \text { Eurospher } 100-5 \mathrm{C}_{18} \\
\text { Identification: was HPLC/DAD/ESI }{ }^{ \pm}-\mathrm{MS}^{\mathrm{n}}, \\
150 \times 2.1 \mathrm{~mm}, 5 \mu \mathrm{m} . \lambda 280,325,360 \text { and } 520 \mathrm{~nm}\end{array}$ & [98] \\
\hline Costa Rican guava & $\begin{array}{l}\text { Ellagic acid, myricetin, quercitrin, } \\
\text { and quercetin }\end{array}$ & $\begin{array}{l}\mathrm{MeOH} / \mathrm{H}_{2} \mathrm{O}(70 \mathrm{~mL} / 100 \mathrm{~mL}) \\
\text { Freeze-dryed pulp, mechanical } \\
\text { dispersion }\end{array}$ & $\begin{array}{l}\text { LC-TOF-ESI }{ }^{ \pm}(\mathrm{m} / \mathrm{z} \text { range 100-1000), Synergi Hydro } \\
\text { RP 80A } 250 \times 4.6 \mathrm{~mm}, 4 \mu \mathrm{m} .\end{array}$ & [110] \\
\hline $\begin{array}{l}\text { Brazilian guava, } \\
\text { jambolan, nance, and } \\
\text { lúcuma }\end{array}$ & $\begin{array}{l}\text { Hydrolyzable and condensed tannins, } \\
\text { flavonols, and flavanols }\end{array}$ & $\begin{array}{l}\text { Acetone } / \mathrm{H}_{2} \mathrm{O} / \mathrm{HCOOH} \\
(70: 29: 1) . \text { Freeze-dryed pulp, } \\
\text { accelerated solvent extraction }\end{array}$ & $\begin{array}{l}\text { HPLC-DAD-ESI }{ }^{-} \text {MS }^{\text {n }} \text {, Aqua RP18 } \\
150 \times 2.0 \mathrm{~mm}, 3 \mu \mathrm{m} .\end{array}$ & [113] \\
\hline Solanum lycopersicum L. & $\begin{array}{l}\text { e.g., caffeic acid hexosides, } \\
\text { homovanillic acid hexoside, and } \\
\text { dicaffeoylquinic acid (increasing } \\
\text { trend) }\end{array}$ & $\begin{array}{l}\text { Methanol }(\mathrm{MeOH}) / \mathrm{H}_{2} \mathrm{O} \\
(80 \mathrm{~mL} / 100 \mathrm{~mL})\end{array}$ & $\begin{array}{l}\text { HPLC-DAD-ESI }{ }^{-} \text {-MS } / M S \text {, Zorbax 300SB-C }{ }_{18} \\
\text { column }(2.1 \times 150 \mathrm{~mm} ; 5 \mu \mathrm{m})\end{array}$ & [115] \\
\hline Dried and candied fruit & $\begin{array}{l}\text { Vanillic, ellagic, gallic, p-coumaric, } \\
\text { chlorogenic, caffeic, ferulic, } \\
\text { rosmarinic acids, and myricetin, } \\
\text { quercetin, kaempferol, delphinidin, } \\
\text { cyanidin, and pelargonidin }\end{array}$ & $\begin{array}{l}\mathrm{MeOH} / \mathrm{H}_{2} \mathrm{O}(62.5 \mathrm{~mL} / 100 \mathrm{~mL}) \\
\text { Sonication }\end{array}$ & $\begin{array}{l}\text { HPLC-DAD at 260, 280, 329, and } 520 \mathrm{~nm} \text {. } \\
\text { Zorbax Eclipse Plus } C_{18} \text { column } 150 \times 4.6 \mathrm{~mm}, 3.5 \mu \mathrm{m}\end{array}$ & [118] \\
\hline Pink guava & $\begin{array}{l}\text { Ellagitannins, flavones, flavonols, } \\
\text { flavanols, proanthocyanidins, } \\
\text { dihydrochalcones, and } \\
\text { anthocyanidins, and non-flavonoids } \\
\text { such as phenolic acid derivatives, } \\
\text { stilbenes, acetophenones, and } \\
\text { benzophenones }\end{array}$ & $\begin{array}{l}\text { Freeze dried pulp, } \mathrm{MeOH} / \mathrm{H}_{2} \mathrm{O} \\
(90: 10) \text {, sonication }\end{array}$ & $\begin{array}{l}\text { UHPLC-DAD-ESI }{ }^{+} \text {-MS/MS, BHE Shield RP18 } \\
150 \times 2.1 \mathrm{~mm}, 1.7 \mu \mathrm{m} .\end{array}$ & [119] \\
\hline
\end{tabular}

Gordon and coworkers used accelerated solvent extraction (ASE) to characterize polyphenolic compounds in Psidium guineense Sw., Syzygium cumini (L.) Skeels, Byrsomina crassifolia (L.) Kunth, and Pouteria macrophylla (Lam.) Eyma. [113]. ASE techniques allow for multiple extractions simultaneously. Swifter assays are obtained which, in turn, expedite research results and minimize solvent waste [114] when compared to common extraction methods (e.g., Soxhlet, sonication). Anton and coworkers investigated the effect of ripening in tomato polyphenols content and antioxidant capability. A differential mass spectrometry approach allowed the authors to conclude that cultivar-dependent patterns are observed during ripening (e.g., maximum concentrations of polyphenols achieved half-ripe stage) [115]. Radovanović and coworkers, associated polyphenols from berries to antibacterial activity [116]. Veljković and coworkers analyzed phenolic compounds in different types of tea. Nettle/pineapple, and bearberry/raspberry teas showed the lowest and highest phenolic contents, respectively [117]. Miletić assessed polyphenols in dried and candied fruit. In this particular case, acid hydrolysis was applied to the previously dispersed methanolic extracts to free matrix-bound polyphenols [118]. One g tert-butyl hydroquinone/100 mL was added during extraction as a radical sink to protect polyphenols. Kowalska and coworkers used preparative chromatography to remove non-phenolics [98].

Tentative screening for Psidium friedrichsthalianum (Berg) Niedenzu pulp showed 1,5-dimethyl citrate, 1-trans-cinnamoyl- $\beta$-D-glucopyranoside, sinapic aldehyde-4-O- $\beta$-D-glucopyranoside, 1,3-O-diferuloylglycerol, and 3,3',4-tri-O-methylellagic acid-4'-O-D-glucopyranoside [110]. Phenolic compounds from pink guava from Costa Rica have been recently reported, $n=60$ phenolic compounds were characterized. The authors report for the first time in P. guajava $n=42$ compounds in the fruit's peel and flesh, and $n=24$ new compounds, e.g., phlorizin, nothofagin, astringin, chrysin-C-glucoside, valoneic acid bilactone, cinnamoyl-glucoside, and two dimethoxy cinnamoyl-hexosides [119]. During polyphenol analysis, HLB ${ }^{\circledR}$ SPE (Hydrophilic-Lipophilic, 
Balance Solid Phase Extraction) cartridges are used routinely for clean-up. At least one research group has applied this approach to assay polyphenols and vitamin C in plant-derived materials [121]. Interestingly, when using the Folin-Ciocalteu spectrophotometric approach, ascorbate is considered interference and must be eliminated from the eluate (usually taking advantage of ascorbate thermolability) or else the measurements are overestimated. However, simultaneous retention of both analytes in the SPE cartridge can be exploited, if HPLC methods are used instead. We recommend that in countries in which fruits with high polyphenol content are readily available (and in considerable quantities), preparative separation of polyphenol fractions is a possibility for obtaining pure compounds (See for example, [122]). Finally, vanillic acid was reported in cocoa pod polyphenol-rich extracts. Interestingly, the application of $2000 \mathrm{mg} \mathrm{L}^{-1}$ of this cocoa extract to a vegetable oil improved its oxidative stability and shelf-life [123].

Method Application Experience

In our laboratory, ultrasound-assisted extraction is preferred for reducing processing time and avoiding degradation of the compounds. Additionally, polyphenols are quite light sensitive, hence yellow lights are used during the extraction using acetone-water or methanol-water solutions. As the polyphenol family is extensive and chemically diverse, a surface response design is always recommended to assess the appropriateness of the solvent system (i.e., selecting a solvent that provides the highest yields). Samples with a high lipid content (i.e., $>5 \mathrm{~g}$ total fat $/ 100 \mathrm{~g}$ ) usually cause significant interferences and must be defatted previous to polyphenol extraction. It is usual to add additional antioxidants (e.g., ascorbic acid) to polyphenol extracts to protect them from oxidation. Finally, it is common to find natural existing polyphenols as adducts with protein or carbohydrate moieties. These adducts are usually formed by non-covalent interactions (e.g., salt bridges); therefore, by adjusting the extract ionic strength, one can remove these artifacts. Sugar adducts are considerably more difficult to analyze since only a few compounds are commercially available (e.g., cyanidin 3-O-glucoside chloride). Hydrolysis (mild acidic, basic or enzymatic) is the usual approach to circumvent the lack of these commercial standards. Availability of mass spectrometry or nuclear magnetic resonance (NMR) can help elucidate unknown compounds and adducts.

\subsection{Capsaicinoids}

Capsaicinoids are plant metabolites from the Capsicum genus which give pungency to chili peppers [124]. Scoville scale which measures the spiciness of the fruits (originally, tested by sensory assays) is reported in function of capsaicin concentration (i.e., $\mathrm{mg}$ capsaicin $\mathrm{kg}^{-1} \times 16$ [125]). Today, the most reliable, rapid, and efficient method to identify and quantify capsaicinoids is HPLC. Measurement of this molecules is significant as a quality measure of chili pepper ( 22 domesticated varieties consumed regularly worldwide), a crop which is of significant cultural and global trade market value [126]. More than 20 different capsaicinoids have been described; the foremost capsaicinoids found in these plant structures include capsaicin and dihydrocapsaicin [127] (Figure 2).

A<smiles>COc1cc(CNC(=O)CC/C=C/C(C)C)ccc1O</smiles>

B<smiles>COc1cc(CNC(=O)CCCCC(C)C)ccc1O</smiles>

Figure 2. Chemical structures for (A) capsaicin (8-methyl- $N$-vanillylamide) and (B) dihydrocapsaicin (8-methyl- $N$-vanillylnonamide), the aromatic vanillyl radical is shown in red.

\subsubsection{Measurement of Capsaicin and Dehydrocapsaicin in Real Samples}

Research reports have described capsaicinoid analysis; the most recent are summarized in Table 5. Garcés-Claver and coworkers determined capsaicin and dihydrocapsaicin in two different scenarios, 
i.e., fruits grown in summer and then in spring [128]. The authors concluded that capsaicinoids varied largely among fruit families and that these families did not respond similarly to producing these capsaicinoids when their fruits were grown in the two seasons tested [128].

Table 5. Common chromatographic conditions used for capsaicinoid analysis.

\begin{tabular}{|c|c|c|c|c|}
\hline Matrix & Extraction Method & $\begin{array}{l}\text { Measurement Method, } \\
\text { Chromatographic Column }\end{array}$ & $\begin{array}{l}\text { Sensitivity, } \mathrm{mg} \mathrm{L}^{-1} \text { or } \mathrm{mg} \\
\mathrm{kg}^{-1} \text { Fruit Dry Weight }\end{array}$ & Reference \\
\hline Peppers Capsicum annuиm $\mathrm{L}$. & ACN, mechanical shaking & $\begin{array}{l}\text { RP-LC/MS-TOF/ESI }{ }^{-}, \\
\text {pseudo-molecular ions }[\mathrm{M}-\mathrm{H}]^{-} \\
304.2 \text { and } 306.2 \mathrm{~m} / \mathrm{z} \text {. IS } \\
4,5 \text {-dimethoxybenzyl)-4-methyloctamide, } \\
250 \times 4.6 \mathrm{~mm}, 5 \mu \mathrm{m}\end{array}$ & 0.06 & [128] \\
\hline $\begin{array}{l}\text { Natural capsaicinoid mixture } \\
\text { (capsaicin/dihydrocapsaicin 67:33) }\end{array}$ & $\begin{array}{l}\mathrm{C}_{7} \mathrm{H}_{16} / \mathrm{EtAOc} / \mathrm{MeOH} / \mathrm{H}_{2} \mathrm{O} \\
(1: 1: 1: 1)\end{array}$ & $\begin{array}{l}\text { 1. Sequential centrifugal partition } \\
\text { chromatography. } \\
\text { 2. Nucleosil 100-5 } \mathrm{C}_{18} \text { column } \\
(125 \times 3 \mathrm{~mm}, 5 \mu \mathrm{m}, \mathrm{UV} 280 \mathrm{~nm}\end{array}$ & Preparative chemistry & [129] \\
\hline $\begin{array}{l}\text { Hot chilies, green peppers, red } \\
\text { peppers, and yellow peppers }\end{array}$ & $\mathrm{EtOH}$ & $\begin{array}{l}\text { HPLC-UV using a wavelength of } \\
222 \mathrm{~nm} \text { and a Betasil } C_{18} 150 \times \\
4.6 \mathrm{~mm}, 3 \mu \mathrm{m} \text { column }\end{array}$ & 0.10 & [130] \\
\hline Vegetable and waste oils & $\begin{array}{l}\text { Immunoaffinity column, } \mathrm{SPE} \\
\text { loading solvent, } 5 \mathrm{~mL} \\
\mathrm{MeOH} / \mathrm{H}_{2} \mathrm{O}(5: 95) \text {, washing } \\
\text { solvent } \mathrm{PBS}, \mathrm{MeOH} \text { for elution }\end{array}$ & $\begin{array}{l}\text { LC-ESI }^{+} \text {-MS/MS, Hypersil Gold, } \\
100 \times 2.1 \mathrm{~mm}, 3.0 \mu \mathrm{m}\end{array}$ & 0.03 & [131] \\
\hline Edible and crude vegetable oils & $\mathrm{SPE} \mathrm{C}_{18}, \mathrm{MeOH}$ & $\begin{array}{l}\text { IS capsaicin- } \mathrm{d}_{3} \text {, and } \\
\text { dihydrocapsaicin- } \mathrm{d}_{3} \text {. } \\
\text { RP-UPLC-ESI-MS/MS, ZORBAX } \\
\text { Eclipse Plus } \mathrm{C}_{18} 50 \times 2.1 \mathrm{~mm}, \\
1.8 \mu \mathrm{m})\end{array}$ & 0.5 & [132] \\
\hline Austrian chili peppers & $\mathrm{ACN} / \mathrm{H}_{2} \mathrm{O}(35: 65)$ & $\begin{array}{l}\text { UV and FLD } \lambda_{\mathrm{ex}} 280 \text { and } \lambda_{\mathrm{em}} \\
310 \mathrm{~nm}, \mathrm{UPLC}{ }^{\mathrm{TM}} \mathrm{BEH} \mathrm{C}_{18} 50 \times 2.1 \\
\mathrm{~mm}, 1.7 \mu \mathrm{m}\end{array}$ & 0.136 & [133] \\
\hline Brazilian Capsicum chinense Jacq. & $\mathrm{MeOH}$ sonication & $\begin{array}{l}\text { UHPLC-DAD-APCI-MS/MS, } \\
\text { Hypersil Gold C } \mathrm{C}_{18} 100 \times 3 \mathrm{~mm}, \\
1.9 \mu \mathrm{m}\end{array}$ & 0.0027 & [134] \\
\hline South Korean red peppers & $\mathrm{MeOH} / \mathrm{H}_{2} \mathrm{O}(95: 5), 80^{\circ} \mathrm{C} 2 \mathrm{~h}$ & $\begin{array}{l}\text { FLD } \lambda_{\text {ex }} 280 \text { and } \lambda_{\text {em }} 325 \mathrm{~nm}, \\
\text { Zorbax Eclipse XDB-C }{ }_{18} 75 \times 3 \mathrm{~mm} \text {, } \\
3.5 \mu \mathrm{m})\end{array}$ & 0.06 & [135] \\
\hline
\end{tabular}

SPE: Solid phase extraction. UPLC: Ultra-Performance Liquid-Chromatography.

Goll and coworkers optimized a cyclic solid support free liquid-liquid partition to separate a capsaicin and dehydrocapsaicin mixture into two sequentially collected product streams. This approach may serve as a base for compound purification before chemical characterization. With this optimization, the authors demonstrated theoretical and predictive tools are useful in preparative chemistry and process design [129].

The pretreatment of capsaicinoid determination (i.e., extraction steps) is usually straightforward, and the majority of methods are based on methanol-based extraction. However, Lu and coworkers reviewed several techniques that can be used to extract capsaicinoids successfully [136]. Ma and coworkers [131] used capsaicin and dihydrocapsaicin, and nonivamide [132] were selected as adulteration markers to authenticate vegetable oils. No capsaicinoid compounds were found in edible vegetable oils, thereby ruling out a possible adulteration source. The authors prepared immunosorbents by covalently coupling highly specific capsaicinoid polyclonal antibodies with CNBr-activated Sepharose 4B and packed into a polyethylene column [131]. This research is interesting, from the clean-up standpoint, since the authors adjusted the major parameters affecting the immunoaffinity column extraction efficiency (i.e., loading, washing, and eluting conditions) [131]. Schmidt and coworkers compared different chili peppers available in Austria and compared their contents of capsaicin and dihydrocapsaicin [133]. The authors used UPLC (Ultra-Performance Liquid-Chromatography) and hence obtained a reduced resolved chromatogram for both compounds of just $1.7 \mathrm{~min}$. [133]. The authors also corroborated that the highest capsaicinoids content was in the fruits' placenta and the seeds. Similarly, Sganzerla and coworkers obtained a complete separation under $4 \mathrm{~min}$ [134]. The above examples correspond to high-throughput methods of analysis.

Finally, ingested capsaicinoids can persist in the bloodstream and can be determined in plasma using LC coupled with tandem mass spectrometry [137]. Intestinal absorption and metabolisms (via capsaicinoid glucuronides) have also been reported for a mammal [138]. At the same time, 
dietary capsaicin has been linked to the browning of adipose tissue, which in turn, promotes energy expenditure [139].

\subsubsection{Method Application Experience}

As shown, capsaicinoids can very well be measured by using a wavelength in the $200-400 \mathrm{~nm}$ UV range. However, fluorescence analysis can be performed $\left(\lambda_{\mathrm{ex}} 280 \mathrm{~nm} \lambda_{\mathrm{em}} 338 \mathrm{~nm}\right)$ improving sensitivity dramatically [134], an approach preferred by our laboratory for routine analysis. A short column with a smaller particle size seems to improve both resolution and sensitivity.

\subsection{Caffeine and Theobromine}

Caffeine and theobromine are naturally occurring methylxanthines with antioxidant potential [140] (Figure 3). There are some misconceptions regarding health effects caused by caffeine ingestion [140]. On the contrary, theobromine (and cocoa) consumption has demonstrated beneficial effects [141]. Coffee, cocoa, tea, and caffeine-containing beverages (e.g., soft and energy drinks) are widespread and relevant food commodities. For example, caffeine intake has been calculated at 25 and $50 \mathrm{mg}$ per day for children and adolescents aged 2-11 and 12-17 years, respectively. The more relevant caffeine sources were soda and tea as well as flavored dairy (for children aged $<12$ years) and coffee (for those aged 12 years and above). Similarly, caffeine consumption has been between 2.5-3 and $400 \mathrm{mg} \mathrm{kg}^{-1} \mathrm{bw}$ (body weight) day ${ }^{-1}$ for children and adults, respectively $[142,143]$. The evidence is suggesting an alimentary impact as some nutrients are poorly absorbed when combined with alkaloids [140]. Caffeine analysis is common in the food industry (e.g., quality control in beverages) and research (e.g., alkaloid carrying plants); it has also been incorporated in academia and student curricula [144].<smiles>Cn1c(=O)c2c(ncn2C)n(C)c1=O</smiles><smiles>Cn1cnc2c1c(=O)[nH]c(=O)n2C</smiles><smiles>Cn1c(=O)c2[nH]cnc2n(C)c1=O</smiles><smiles>Cn1c(=O)[nH]c2ncn(C)c2c1=O</smiles><smiles></smiles>

$\mathrm{F}$<smiles>Cn1c(=O)c2c(ncn2C)n(C)c1=O</smiles><smiles>C#CC#C</smiles><smiles></smiles><smiles>Cn1cnc2[nH]c(=O)[nH]c(=O)c21</smiles><smiles></smiles><smiles>[2H]C(=O)Nc1[nH]c(=O)n(C)c(=O)c1NC(C)=O</smiles><smiles></smiles><smiles>CC(=O)Nc1c(N)[nH]c(=O)n(C)c1=O</smiles>

Figure 3. Chemical structures for (A) caffeine (1,3,7-trimethylxanthine), (B) theobromine (3,7-dimethylxanthine), (C) theophylline (1,3-dimethylxanthine), (D) paraxanthine (1,7-dimethylxanthine), and (E) antipyrine (2,3-Dimethyl-1-phenyl-3-pyrazoline-5-one or phenazone). (F) Caffeine biotransformation pathway is dependent on the CYP1A2 and CYP2A6 enzyme system. 1. 1,3,7-trimethylxanthine 2. 1,7-dimethylxanthine 3. 7-methylxanthine 4. 7-methyluric acid 5. 1-mthyluric acid 6. 5-acetylamino-6-formylamino-3-methyluracil 7. 1,7-dimethyluric acid 8. 5-acetylamino-6-amino-3-methyluracil [145]. 


\subsubsection{Alkaloid Analysis and Reported Application to Real Samples}

Several methods have been developed for alkaloid analysis in food samples. Also, methods for studying the fate of these alkaloids have been documented (Table 6). For example, Grujić-Letić and coworkers, analyzed 12 commercial tea and coffee products, non-alcoholic energy drinks and foods (including mate, green tea, and black tea), 5 combined preparations of over the counter non-steroid anti-inflammatories and water samples collected from 7 representative locations of the Danube River [146]. This paper represents a clear example of method versatility, as a single analyte was recovered, from variable matrices, and assessed using a similar procedure. This analysis was not only used for characterization, but also demonstrated a potential for quality control in commercial products (e.g., compliance of the nutritional label) and water. In water samples, the highest caffeine concentration found was $306.120 \pm 0.082 \mathrm{ng} \mathrm{L}^{-1}$ during springtime. Gonçalves and coworkers recently demonstrated that caffeine might be a suitable chemical marker of domestic wastewater contamination in surface waters [147].

Table 6. Summary of conditions regarding alkaloid analysis.

\begin{tabular}{|c|c|c|c|c|}
\hline Matrix & Extraction Method & $\begin{array}{c}\text { Measurement Method, } \\
\text { Chromatographic Column }\end{array}$ & $\begin{array}{c}\text { Sensitivity, mg } \\
\mathrm{L}^{-1} \text { or } \mathrm{mg} \mathrm{kg}^{-1}\end{array}$ & Reference \\
\hline \multicolumn{5}{|c|}{ Food Samples } \\
\hline Energy drinks & Sonication for degassing & $\begin{array}{l}\text { DAD } 270 \mathrm{~nm} \text { (caffeine) Nova-Pak } \mathrm{C}_{18} \\
150 \times 3.9 \mathrm{~mm}, 5 \mu \mathrm{m} \text {, mobile phase: } \\
\mathrm{MeOH}, \mathrm{NaH}_{2} \mathrm{PO}_{4} / \text { hexanesulfonic } \\
\text { acid }\left(\mathrm{C}_{6} \mathrm{H}_{13} \mathrm{SO}_{3} \mathrm{H}\right)\end{array}$ & 0.023 & [148] \\
\hline Energy drinks & $\begin{array}{l}\text { Sonication for degassing. } \\
\text { "Dilute and shoot" }\end{array}$ & $\begin{array}{l}25 \mathrm{mmol} \mathrm{L} \mathrm{L}^{-1} \mathrm{NaAOc} / \mathrm{HAOC} \text { buffer, } \\
\mathrm{pH} \text { 6.0, an inertsil OctaDecylSilane-3V } \\
250 \times 4.6 \mathrm{~mm}, 5 \mu \mathrm{m}, \mathrm{UV} 230 \mathrm{~nm}\end{array}$ & 0.19 & [149] \\
\hline Cocoa & $\begin{array}{l}\text { Defat with } \mathrm{C}_{6} \mathrm{H}_{14} \\
\text { Acetone } / \mathrm{H}_{2} \mathrm{O} / \mathrm{HAOc} \\
(70 / 29.5 / 0.5)\end{array}$ & $\begin{array}{l}\text { 1. HPLC } 250 \times 4.60 \mathrm{~mm}, 5 \mu \mathrm{m} \\
\text { 2. UPLC Acquity HSS T3 } \\
100 \times 2.1 \mathrm{~mm}, 1.8 \mu \mathrm{m}\end{array}$ & 0.001 for both LCs & [150] \\
\hline $\begin{array}{l}\text { Cocoa-based } \\
\text { products }\end{array}$ & $\begin{array}{l}\text { Defat by mechanical dispersion } \\
\text { with } \mathrm{C}_{6} \mathrm{H}_{14}, \mathrm{MeOH} / \mathrm{H}_{2} \mathrm{O}(80: 20)\end{array}$ & $\begin{array}{l}\text { UHPLC-Q-Orbitrap-MS/MS } \\
\text { polyphenols }\left(n=35, \mathrm{ESI}^{-}\right) \text {and } \\
\text { alkaloids }\left(n=2, \mathrm{ESI}^{+}\right) \mathrm{Kinetex} \\
\text { biphenyl } 100 \times 2.1 \mathrm{~mm}, 1.7 \mu \mathrm{m}\end{array}$ & $\begin{array}{l}\text { Theobromine } 0.03 \\
\text { caffeine } 0.04\end{array}$ & [151] \\
\hline $\begin{array}{l}\text { Mate beer and } \\
\text { mate soft drinks }\end{array}$ & Sonication for degassing, ACN. & $\begin{array}{l}\text { HP-TLC LiChrospher silica gel plates, } \\
\text { fluorescence indicator and mobile } \\
\text { phase acetone/toluene/chloroform } \\
(4: 3: 3) \text { UV } 274 \mathrm{~nm}\end{array}$ & 0.4 & [152] \\
\hline \multicolumn{5}{|c|}{ Biological Samples } \\
\hline $\begin{array}{l}\text { Human and } \\
\text { synthetic plasma }\end{array}$ & Ultracentrifugation, $12,000 \mathrm{rpm}$ & $\begin{array}{l}\text { Waters Atlantis } \mathrm{C}_{18} 150 \times 4.6 \mathrm{~mm} \text {, } \\
5 \mu \mathrm{m} \text {. Mobile phase: } 15 \mathrm{mmol} \mathrm{L}{ }^{-1} \\
\text { PBS (pH 3.5)/ACN (83:17). PDA } 274 \\
\text { nm, IS: antipyrine }\end{array}$ & 0.02 & [153] \\
\hline Human saliva & Chloroform/isopropanol (85:15) & $\begin{array}{l}\text { Mobile phase: } \\
\mathrm{H}_{2} \mathrm{O} / \mathrm{HAOc} / \mathrm{MeOH} / \mathrm{ACN}(79: 1: 20: 2) \\
\mathrm{Kromasil} 100 \mathrm{C}_{18} 250 \times 4.6 \mathrm{~mm}, 5 \mu \mathrm{m}, \\
30^{\circ} \mathrm{C} \text {, UV } 273 \mathrm{~nm}\end{array}$ & 0.032 & [154] \\
\hline $\begin{array}{l}\text { Human and } \\
\text { neonate plasma }\end{array}$ & $\begin{array}{l}\text { SPE polymeric 96-well plates } \\
\text { Strata- } \mathrm{X}^{\mathrm{TM}} \text {. Elution: } \\
\mathrm{MeOH} / \mathrm{H}_{2} \mathrm{O} / \mathrm{HAOc}(70: 29: 1)\end{array}$ & $\begin{array}{l}10 \mathrm{mmol} \mathrm{L}-1 \text { PBS }(\mathrm{pH} 6.8) / \mathrm{ACN} \\
\text { (gradient mode). Zorbax }{ }^{\circledR} \mathrm{SB}-\mathrm{Aq} \\
\text { narrow bore RR } 100 \times 2.1 \mathrm{~mm} \text {, } \\
3.5 \mu \mathrm{m}), 40^{\circ} \mathrm{C} \text {, UV } 273 \mathrm{~nm}\end{array}$ & 0.1 & [155] \\
\hline
\end{tabular}

Shrestha and coworkers developed a method for use as quality control. Concentrations of Nepalese tea and coffee ranged from 1.10 to $4.30 \mathrm{mg}$ caffeine $\mathrm{kg}^{-1}$ dry basis [156]. Fajara and Susanti

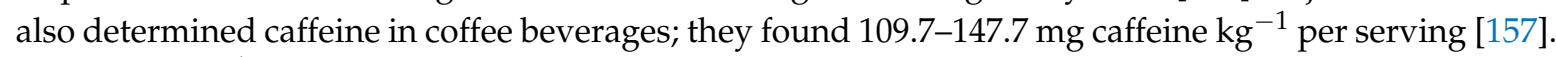
Gliszczyńska-Świgło and Rybicka used both a photodiode and fluorescence detector to monitor both caffeine and water-soluble vitamins, simultaneously, in energy drinks [148]. Aşçı and coworkers analyzed caffeine in soft drinks [158]. The authors used Behnken response surface design to optimize

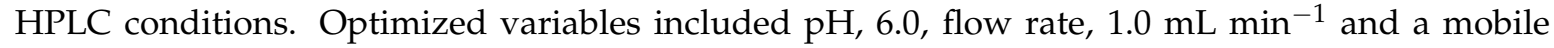
phase ratio, 95\% [158]. Similarly, preservatives sorbate and benzoate also can be determined with caffeine simultaneously in sports drinks [149]. Ortega and coworkers compared data from HPLC- and UPLC-MS/MS (MS/MS also known as tandem mass spectrometry). The authors analyzed procyanidin 
oligomers (mono to nonamers) and catechin, epicatechin, caffeine, theobromine. The analysis was performed under 12.5 min [150]. Recently, Rodríguez-Carrasco and coworkers used to analyze polyphenols and alkaloids in cocoa-based products. Mainly, they compared three different coffee varieties including "Forastero", "Trinitario", and "Criollo". Mostly, theobromine was found in major quantities relative to caffeine except Criollo 70 and $75 \%$ where the theobromine/caffeine ratio is ca. 1:1. Of all samples examined, Criollo varieties showed the highest quantities of alkaloids. [151]. Interestingly, a positive association has been described between cacao polyphenol absorption and theobromine [159]. Other identifying markers, such as fatty acids, have also been reported as tools for discrimination among coffee varieties. The authors were able to discern Coffea arabica (Arabica) and Coffea canephora (Robusta) using $\sum$ MUFA, 18:3n3, $\sum$ MUFA/ $\sum$ SFA [160].

\subsubsection{Alkaloid Bioavailability and Transference to Biological Samples}

Caffeine is rapidly absorbed following oral consumption; maximum blood (plasma) levels are usually reached within $30 \mathrm{~min}$ [140]. Caffeine bioavailability studies have been performed in human plasma, for example, Alvi and Hummami monitored caffeine and antipyrine (Figure 3). Caffeine in human plasma was stable for at least $24 \mathrm{~h}$ at room temperature or 12 weeks at $-20^{\circ} \mathrm{C}$ [153]. Caffeine is a demonstrated therapeutic agent for apnea of prematurity. Hence, López-Sánchez developed a method to monitor caffeine in serum to demonstrate that the drug had achieved its therapeutic levels (i.e., 30 or $35 \mu \mathrm{g} \mathrm{mL}^{-1}$ ) [161]. Cleanup using SPE adapted in multiple well plates, as the one used in the former study, is an easy way to process several samples simultaneously, instead of the one-on-one cartridge approach. Only in $85 \%$ and $78 \%$ of the cases studied, maternal and newborn absorption of caffeine was demonstrated, respectively. Another research group investigated caffeine metabolism based on CYP1A2 enzyme activity. The presence and ratio of theophylline, paraxanthine, theobromine, and caffeine (Figure 3) was evaluated in human saliva [154]. The authors collected saliva of healthy subjects after consumption of a caffeinated beverage and obtained data of compared chromatographic profiles from the saliva of smoking (active xenobiotic hepatic metabolism) and non-smoking subjects [154]. Saliva, plasma, and urine already have been demonstrated valuable to intervention studies for cocoa [155,162]. Kobayashi used differential chromatogram analysis to narrow the signal width for caffeine, in urine samples, to improve separation demonstrating that peak enhancing posterior to injection is possible [163]. Finally, Ramdani and co-workers incorporated green and black tea powder into bovine diets demonstrating that alkaloids, catechins, and theaflavins diminished ammonia and methane productions without any detrimental effect on rumen functions in vitro [51].

Although theobromine is not a usual analyte for feed analysis, is noteworthy that the 2002/EC/32 regulation sets limits for the analyte at $300 \mathrm{mg} \mathrm{kg}^{-1}$ for compound feed, except for adult cattle feed, where the threshold is laxer (i.e., $700 \mathrm{mg} \mathrm{kg}^{-1}$ ).

\subsubsection{Method Application Experience}

Tea and coffee sample extracts are rich in tannins and other non-desired compounds that may generate matrix effects and reduce the shelf life of an analytical column. We have successfully used $\mathrm{MgO}$ to remove said interferences while increasing the extract $\mathrm{pH}$. An alkaline medium ensures positively charged alkaloid molecules. Furthermore, defatting is vital for an adequate recovery when a lipid-rich sample is treated (e.g., cacao seeds, $>30 \mathrm{~g}$ total fat $/ 100 \mathrm{~g}$ ), especially, if aqueous extracting is employed. We suggest the use of efficient organic solvents; $n$-hexane, petroleum benzine, for example, have been exploited. Minimal amounts possible should be used, as this otherwise generates waste. Chlorinated solvents and ethyl ether should be avoided, as alkaloids exhibit some degree of solubility in these solvents which, in turn, may affect recovery. 


\subsection{Cholesterol}

Cholesterol ((3S,8S,9S,10R,13R,14S,17R)-10,13-dimethyl-17-[(2R)-6-methylheptan-2-yl]2,3,4,7,8, $9,11,12,14,15,16,17$-dodecahydro- $1 H$-cyclopenta[a]phenanthren-3-ol), is a waxy steroid metabolite found in the cell membranes and transported in the blood plasma of all animals [164]. This sterol plays a role in metabolic (e.g., precursor for bile acids and steroid hormones) and structural processes (e.g., regulates biological membrane fluidity) $[165,166]$. Cholesterol can be introduced to the metabolism through de novo synthesis or diet [162]. In plant structures, similar compounds are found such as phytosterols and stanols [167]. However, when analyzing cholesterol, one must consider that the amount of cholesterol made by many plants is not negligible [168]. Nutritional information regarding cholesterol content in food and intake through dietary sources is relevant, as overload can drastically increase plasma cholesterol levels and, hence, health risks. From a methodological standpoint, a considerable advantage in using the LC approach is that lipid oxidation is negligible, as measurements can be performed at relatively low temperatures. Herein are detailed some examples of cholesterol analysis in food samples (Table 7).

Albuquerque and coworkers compared both HPLC and UPLC for the analysis of eggs, egg yolks, sour cream, and chicken nuggets. The latter approach rendered a method with 8-fold less solvent waste and ca. 4-fold more sensitivity, with a decreased analysis time (i.e., $4 \mathrm{~min}$ ) [166]. The initial sample mass used from the assay was optimized; $0.25 \mathrm{~g}$ and $1 \mathrm{~g}$ for samples with relative lower (e.g., sour cream) and higher (e.g., egg yolk) cholesterol contents. The authors also compared different cooking methods for the chicken nuggets (baked vs. deep frying). They found that cholesterol content was higher in the oven baked goods. This is a result of the processing as the meat loses water during baking. Meanwhile, water/oil exchange occurs during frying. Although several solvents were tested, the authors concluded that an acetonitrile/2-propanol solvent system was the most successful in eluting the cholesterol molecule [166]. Cholesterol analysis usually renders clean chromatograms since most interferences are eliminated by saponification. Saponification segregates the molecule of interest from the saponifiable lipid fraction (e.g., acylglycerols) and hydrolyzes cholesterol esters. This step has been considered critical for cholesterol analysis in food matrices [166]. Furthermore, Cruz and coworkers, quantitatively, compared several extraction methods on freeze dried and thawed seafood samples [169]. In this regard, the direct saponification and extraction considerably reduce solvent waste, while the Smedes method used non-chlorinated solvents (is a greener approach). Better recoveries for vitamin E are obtained when the analysis is performed before saponification step (e.g., modified Folch, Smedes). The authors were able to analyze $\alpha$-tocopherol, cholesterol, and fatty acids all from the same extract and applied the optimized method to octopus, squid, mackerel, and sardine successfully. From the assayed samples, squid and sardine showed higher values of cholesterol and vitamin E, respectively. Interestingly, normal phase chromatography was used to assess vitamin E [169]. Saldanha and Bragagnolo also used normal phase chromatography. The authors used very mild conditions during saponification, which are paramount to avoid cholesterol oxidation. Also, they monitored cholesterol contents after heat treatment and demonstrated that it decreased significantly, with a simultaneous increase of the cholesterol oxides contents (i.e., 19-hydroxycholesterol, 24(S)-hydroxycholesterol, 22(S)-hydroxycholesterol, 25-hydroxycholesterol, 25(R)-hydroxycholesterol, and 7-ketocholesterol) [170]. Bauer and coworkers analyzed cholesterol and cholesterol oxides in milk samples using reversed-phase chromatography. [171]. The presence of cholesterol oxides can indicate the source and nature of the food, as well as the storage and processing conditions suffered by a commodity. The authors conclude that milk has physicochemical characteristics that make it more resistant to oxidation of cholesterol compared to other products of animal origin. In this regard, several sample preparation methods for cholesterol oxides have been detailed elsewhere [173]. Daneshfar and coworkers used dispersive liquid-liquid microextraction as an alternative to the extraction and clean-up steps in sample preparation [172]. In this case, ethanol was used as a disperser solvent and carbon tetrachloride as an extraction solvent [172]. This work is a fine example of parameter optimization during method validation; different dispersion (i.e., $\mathrm{EtOH}$, acetone, and $\mathrm{ACN}$ ) 
and extraction (i.e., $\mathrm{CS}_{2}, \mathrm{CH}_{2} \mathrm{Cl}_{2}, \mathrm{CHCl}_{3}$, and $\mathrm{CCl}_{4}$ ) solvents were tested, as well as variables such as $\mathrm{pH}$, volume and time. However, the authors fail to explain how they obtain total cholesterol from a complex matrix (for example, a method must be able to free cholesterol from its esterified form) when no hydrolysis is performed (i.e., ensuring not just the mere quantification of unbound/free cholesterol).

Table 7. Measurement techniques meant for cholesterol in food samples.

\begin{tabular}{|c|c|c|c|c|}
\hline Matrix & Extraction Method & $\begin{array}{l}\text { Measurement Method, } \\
\text { Chromatographic Column }\end{array}$ & $\begin{array}{l}\text { Sensitivity, } \mathrm{mg} \mathrm{L}^{-1} \text { or } \\
\mathrm{mg} \mathrm{kg}^{-1}\end{array}$ & Reference \\
\hline \multirow{2}{*}{$\begin{array}{l}\text { Egg-, dairy-and } \\
\text { meat-based } \\
\text { products }\end{array}$} & \multirow{2}{*}{ ACN/2-propanol } & 1. Supelcosil ${ }^{\mathrm{TM}}$ LC-18-DB $150 \times 4.6 \mathrm{~mm}, 3 \mu \mathrm{m}$ & 3 & \multirow{2}{*}{ [166] } \\
\hline & & $\begin{array}{l}\text { 2. Acquity UPLC }{ }^{\circledR} \text { BEH C }_{18} 50 \times 2.1 \mathrm{~mm} \text {, } \\
1.7 \mu \mathrm{m}, \mathrm{UV} 210 \mathrm{~nm}\end{array}$ & 0.7 & \\
\hline Seafood & $\begin{array}{l}\text { 1. In situ: } \mathrm{KOH} 2 \mathrm{~mol} \mathrm{~L}-1 / \mathrm{MeOH}, 80^{\circ} \mathrm{C} \text {, } \\
\mathrm{N}_{2}, \mathrm{C}_{6} \mathrm{H}_{14} \\
\text { 2. Modified Folch: } \mathrm{MeOH} / \mathrm{CH}_{2} \mathrm{Cl}_{2}(1: 2) \text {, } \\
\text { saponification } \\
\text { 3. Smedes: 2-propanol/cyclohexane } \\
\text { (1:1.25), saponification }\end{array}$ & $\begin{array}{l}\left.\text { Vitamin E: FLD } \lambda_{\mathrm{ex}} 290 \lambda_{\mathrm{em}} 330\right) \text {. Cholesterol: } \\
\text { UV } 210 \mathrm{~nm} \text {, Supelcosil }{ }^{\mathrm{MM}} \text { LCSI } 75 \times 3.0 \mathrm{~mm} \text {, } \\
3 \mu \mathrm{m} \text {, mobile phase: } n \text {-hexane and 1,4-dioxane } \\
(97.5: 2.5) \text { IS: tocol }\end{array}$ & $\begin{array}{l}\text { Vitamin E: } 0.05 \\
\text { Cholesterol: } 10\end{array}$ & [169] \\
\hline Seafood & $\begin{array}{l}\mathrm{KOH} 50 \mathrm{~g} / 100 \mathrm{~g} / \mathrm{EtOH}, 25^{\circ} \mathrm{C}, 22 \mathrm{~h} \text {, in the } \\
\text { dark, } \mathrm{C}_{6} \mathrm{H}_{14}\end{array}$ & $\begin{array}{l}\text { 1. Nova Pack CN HP } 300 \times 3.9 \mathrm{~mm}, 4 \mu \mathrm{m} \text {, } \\
\text { n-hexane/2-propanol (97:3), UV } 210 \mathrm{~nm} \\
\text { (cholesterol oxides), RID (cholesterol } \\
\text { and epoxides) } \\
\text { 2. Confirmation: HPLC-APCI-MS QTRAP }\end{array}$ & 0.01 & [170] \\
\hline Dairy product & $\begin{array}{l}\mathrm{KOH} 50 \mathrm{~g} / 100 \mathrm{~g} / \mathrm{EtOH}, 25^{\circ} \mathrm{C}, 22 \mathrm{~h} \text {, in the } \\
\text { dark, } \mathrm{C}_{6} \mathrm{H}_{14}\end{array}$ & $\begin{array}{l}\text { Restek } \mathrm{C}_{18} 150 \times 6 \mathrm{~mm}, 5 \mu \mathrm{m}, \text { mobile phase: } \\
\text { ACN/2-propanol (95:5), UV } 202 \mathrm{~nm} \\
\text { 25-hydroxy and cholesterol, } 227 \mathrm{~nm} \\
\text { 7-ketocholesterol }\end{array}$ & 11.10 & [171] \\
\hline $\begin{array}{l}\text { Egg and dairy } \\
\text { product and } \\
\text { vegetable oil }\end{array}$ & $\begin{array}{l}\text { 1. Egg yolk and milk: pretreatment with } \\
\text { ACN } \\
\text { 2. Liquid-liquid dispersion (DLLME) EtOH } \\
(800 \mu \mathrm{L}) / \mathrm{CCl}_{4}(35 \mu \mathrm{L}) \text {. }\end{array}$ & $\begin{array}{l}\text { CLC-ODS-C } 8150 \times 6 \mathrm{~mm}, 5 \mu \mathrm{m} \text {. Mobile phase: } \\
\text { ACN/EtOH (50:50), HPLC-UV } 210 \mathrm{~nm} \text {, }\end{array}$ & 0.01 & [172] \\
\hline
\end{tabular}

It should be pointed out that though the chlorinated solvents are used in very small quantities, they are still classified by the IARC (International Agency for Research on Cancer) as possible human carcinogens (group 2B). Finally, Robinet and coworkers used a cholesterol esterase in an unrelated matrix to avoid chemical saponification [174]. In this regard, cholesterol esterases (most active at $\mathrm{pH}$ $7.0,37^{\circ} \mathrm{C}$, and in the presence of taurocholate) and lipases (most active at $\mathrm{pH} 7.7$, and $37^{\circ} \mathrm{C}$ [175]) are commercially available.

\section{Method Application Experience}

We suggest two major points: i. that it is recommendable to perform the saponification first and then the solvent-aided extraction ii. a response surface design may be useful to optimize the length of the saponification treatment.

\section{Determinations Designed for Feed and Feed Ingredients}

\subsection{Mycotoxins}

\subsubsection{Recent Approaches for the Determination of Mycoxotins in Feeds}

Mycotoxins are secondary metabolites mainly by fungi Aspergillus, Penicillium, Fusarium and Alternaria species, in stress situations, which involve changes in temperature, moisture or $\mathrm{pH}$ in plants $[58,176,177]$. Currently there are more than 400 types of mycotoxins as ubiquitous contaminants in a wide variety of foods $[178,179]$, such as, corn, cocoa, sorghum, wheat, oats, rye, cotton, peanuts, coffee, dairy products, eggs, among others [180]. Among the best known are ochratoxin (OTA), zearalenone (ZEA), trichothecenes, aflatoxin $\mathrm{B}_{1}\left(\mathrm{AFB}_{1}\right)$, fumonisin $\mathrm{B}_{1}\left(\mathrm{FB}_{1}\right)$ and their metabolites. The last two are listed as carcinogenic by the IARC [181]. Mycotoxins, in general, are teratogenic, mutagenic, carcinogenic, and can possess an immunosuppressive effect in both animals and humans [178,182], which can be aggravated by factors such as the animal species, the concentration of the toxin and synergism existing among them, in addition to the health and nutritional status of the animal $[182,183]$. Also, the direct effects on health, including decreased weight gain, feed conversion 
inefficiency, reduced production, and a decrease of the food system profitability, the increase in feedstuff costs, medical treatments, and ineffectiveness when exploiting the genetic potential of animals [183].

At an organ level, in the liver, $\mathrm{AFB}_{1}$ can generate several metabolites, which include aflatoxin $\mathrm{M}_{1}\left(\mathrm{AFM}_{1}\right)$, which is transferred to milk, a complete food nutritionally, and which is vital in the development of the first years of life $[184,185]$. Also, the $\mathrm{AFM}_{1}$ is a compound declared as a carcinogen that is very resistant to pasteurization and freezing $[180,183]$. Therefore, being trawl compounds in the trophic chain, which involve the adverse effects on livestock production, with an obvious risk to the health of consumers, it stresses the need for laboratories to possess the ability to analyze a large number of analytes in a single sample. In this way, the amount of information can be increased, and a wider diagnosis can be made about the safety of the food and feed industry.

In this regard, Table 8 shows a summary of methods developed for the identification and quantification of mycotoxins, by different research groups, focused mainly on animal feed. For example, Njumbe Ediage and coworkers developed a technique capable of determining 25 mycotoxins in cassava meal, peanut cakes, cornmeal, and different sorghum varieties. The most exciting thing, in this case, is how the researchers solved the affinity fact of fumonisin and ochratoxin with the amino groups (due to the presence of carboxylic acid moiety, Figure 4) $[177,186]$. The researcher divided their extract into two portions, one to which formic acid and dichloromethane were added. After cleanup, the two independent shares were remixed evaporated at $40{ }^{\circ} \mathrm{C}$, reconstituted with $\mathrm{MeOH} / \mathrm{H}_{2} \mathrm{O} / \mathrm{CH}_{3} \mathrm{COOH}$, and $5 \mathrm{mmol} \mathrm{L}^{-1} \mathrm{CH}_{3} \mathrm{COO}^{-} \mathrm{NH}_{4}{ }^{+}$. During MS-based mycotoxin separations, flows are usually kept low, so solvent nebulization and evaporation are performed swiftly. The mobile phase is generally accompanied by an acetic or formic acid buffer to improve ionization especially for those compounds without readily ionizable functional groups (e.g., aflatoxins). Also, the formate ion is added in both solvents as one solvent depletes during the gradient separation and the buffer must always be present in a similar proportion $[177,186]$. Dzuman and coworkers and Rasmussen and coworkers, used, as an extraction method, a modification of the QuEChERS method, (Quick, Easy, Cheap, Effective Rugged, and Safe usually used for pesticide analysis). Both research groups coincide that QuEChERS adaptations for mycotoxin analysis open the possibility toward the simultaneous assay of several and distinct groups of contaminants (e.g., pesticides and mycotoxins) $[179,187]$.

Table 8. Measurement techniques meant for mycotoxins in feed samples.

\begin{tabular}{|c|c|c|c|c|}
\hline Matrix & $\begin{array}{c}\text { Number of } \\
\text { Analytes/Execution } \\
\text { Time (min) }\end{array}$ & Extraction Method & $\begin{array}{l}\text { Measurement Method, } \\
\text { Chromatographic Column }\end{array}$ & Reference \\
\hline $\begin{array}{l}\text { Cassava meal, peanut } \\
\text { cakes, cornmeal, } \\
\text { and different sorghum } \\
\text { varieties }\end{array}$ & $25 / 28$ & $\begin{array}{l}\mathrm{MeOH} / \mathrm{CH}_{3} \mathrm{CO}_{2} \mathrm{CH}_{2} \mathrm{CH}_{3} / \mathrm{H}_{2} \mathrm{O} \\
\text { (70:20:10), cleanup was performed } \\
\text { using amino SPE cartridges }\end{array}$ & $\begin{array}{l}\text { LC: Symmetry RP- } 18150 \times 2.1 \mathrm{~mm} \text {, } \\
5 \mu \mathrm{m} \text {, Identification: MS } / \mathrm{MS} / \mathrm{ESI}^{+}\end{array}$ & {$[177,186]$} \\
\hline $\begin{array}{l}\text { Cereals, compound feed } \\
\text { and silages }\end{array}$ & $56 / 50$ & Modified QuEChERS method & $\begin{array}{l}\text { LC: Acquity UP3 HSS T3 } 100 \times 2.1 \mathrm{~mm} \text {, } \\
1.8 \mu \mathrm{m} \text {, Identification: MS/MS/ } \mathrm{ESI}^{ \pm}\end{array}$ & [179] \\
\hline Bovine milk & $10 / 30$ & $\begin{array}{l}\text { Acid acidified ACN and sodium } \\
\text { acetate was used to separate the } \\
\text { aqueous from the hydrophilic } \\
\text { phase from milk }\end{array}$ & $\begin{array}{l}\text { LC: Ascentis Express } \mathrm{C}_{18}, 150 \times 2.1 \mathrm{~mm} \text {, } \\
2.7 \mu \mathrm{m} \text {, Identification: } \mathrm{MS} / \mathrm{MS} / \mathrm{ESI}^{+}\end{array}$ & [185] \\
\hline Silage & $27 / 44$ & Modified QuEChERS method & $\begin{array}{l}\text { LC: Gemini }{ }^{\circledR} \mathrm{C}_{6} \text {-Phenyl } 100 \times 2.0 \mathrm{~mm} \text {, } \\
3 \mu \mathrm{m} \text {, Identification: MS/MS/ESI }{ }^{ \pm}\end{array}$ & [187] \\
\hline Millet and Sorghum & $\begin{array}{l}84 \text { and } 62 \\
\text { respectively/Not } \\
\text { Indicated }\end{array}$ & $\begin{array}{l}\mathrm{ACN} / \mathrm{H}_{2} \mathrm{O} / \mathrm{CH}_{3} \mathrm{COOH}(79: 20: 1) \\
\text { mixture }\end{array}$ & $\begin{array}{l}\text { LC: Gemini }{ }^{\circledR} \mathrm{C}_{18}, 150 \times 4.6 \mathrm{~mm}, 5 \mu \mathrm{m} \\
\text { Identification: } \mathrm{MS} / \mathrm{MS} / \mathrm{ESI}^{ \pm}\end{array}$ & {$[188,189]$} \\
\hline
\end{tabular}



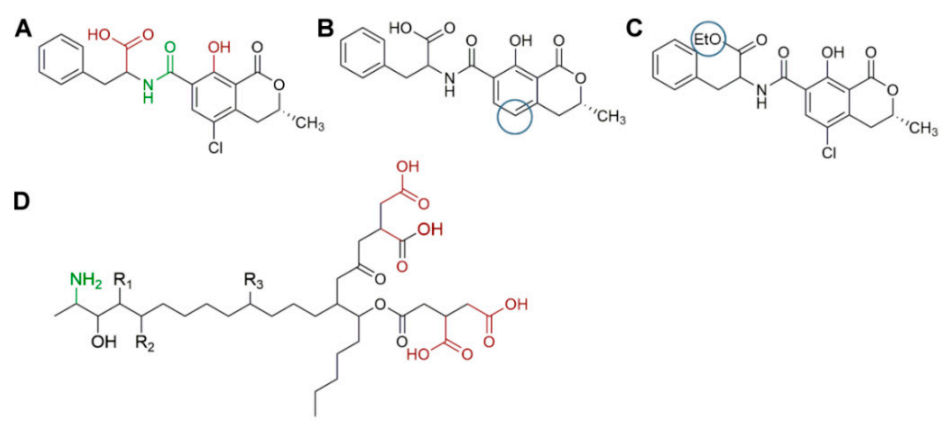

Figure 4. Chemical structures for (A) ochratoxin A, (B) ochratoxin B, (C) ochratoxin C, blue colored circles represent changes in the structure between ochratoxins, loss of $\mathrm{Cl}$ and $\mathrm{OH}$ in ochratoxin $\mathrm{B}$ and $\mathrm{C}$ respectively render a more lipophilic molecule. $\mathrm{Et}=\mathrm{C}_{2} \mathrm{H}_{5}$, and (D) are the general backbone of Fumonisins. $\mathrm{FB}_{1}=721.83 \mathrm{~g} \mathrm{~mol}^{-1} \mathrm{R}_{1}: \mathrm{H} \mathrm{R}_{2}: \mathrm{OH} \mathrm{R}_{3}: \mathrm{OH} ; \mathrm{FB}_{2}=705.84 \mathrm{~g} \mathrm{~mol}^{-1} \mathrm{R}_{1}: \mathrm{OH} \mathrm{R}_{2}: \mathrm{H} \mathrm{R}_{3}: \mathrm{OH}$; $\mathrm{FB}_{3}=705.84 \mathrm{~g} \mathrm{~mol}^{-1} \mathrm{R}_{1}: \mathrm{H} \mathrm{R}_{2}: \mathrm{H} \mathrm{R}_{3}: \mathrm{OH} ; \mathrm{FB}_{4}=689.84 \mathrm{~g} \mathrm{~mol}^{-1} \mathrm{R}_{1}: \mathrm{H} \mathrm{R}_{2}: \mathrm{H} \mathrm{R}_{3}: \mathrm{H}$. Functional groups colored in green and red represent a positively and negatively ionizable moiety, respectively.

\subsubsection{Agricultural by-Products as Feed Ingredients}

Agricultural and food-industry residues are valuable to animal nutrition as they are rich in many bioactive and nutraceutical compounds, such as polyphenolics, carotenoids and dietary fiber among others [190]. Agro-byproducts, used in animal feed, originate from perishable crops and, as such, are susceptible to fungal infection [191]. Hence, mycotoxin surveillance of these materials contemplating the most common contaminants present in such matrices, but also considering emerging contaminants (e.g., beauvericin, enniantins, and fusaproliferin) [191,192] is paramount. The food industry generally includes practices that guarantee the safety of the product meant for human consumption. Residues destined for animal production may not be subject to the same scrutiny. For example, the wine industry with a production estimated at 27 million liters worldwide. Presence of OTA in wine has been widely investigated [193]. However, with the development of new methods, it has been possible to find up to 36 different mycotoxins. (See for example, [194]).

Countries where the production of wine is the predominant, compared to other types of industry, a considerable amount of waste must be repurposed. As such, this might be of use as a ruminant (such as cows and goats) feed ingredient, where the pulp, husks, and seeds, might offer to the animal diet: fiber, energy, fatty acids, and antioxidant compounds which improve ruminal health, echoing in the quality of meat and milk [195-197]. As yet another benefit from this waste processing, the use of grape seeds as mycotoxin adsorbents has been investigated both in vitro [198] and in vivo (e.g., pigs [199]).

\subsection{Antibiotics}

\subsubsection{Recent Multiresidue and Multi-Class Analysis of Antibiotics in Feeds}

Antibiotics are bioactive substances used against bacteria as a therapeutic, metaphylaxis or prophylactic agent both in humans and animals [200-202]. In livestock, some antibiotics are included in animal diets as growth promoter (e.g., monensin, narasin, ractopamine), decrease feed conversion, improve feed efficiency, and overall cost-effectiveness of animal production systems [203,204]. Overuse of veterinary pharmaceuticals in livestock, aquaculture, and the feed industry is reflected in the incidence of residues found in animal-derived food products (e.g., meat, eggs, milk, and honey) [201,205-207]. Antibiotic biotransference through the food chain may contribute to allergic reactions, mutanogenic and cancerogenic effects, found in humans and animals; additional to the growing rates of antimicrobial resistance [208,209]. Considering these issues, organizations worldwide (e.g., European Commission, United States Food and Drug Administration, World Health Organization) have generated protocols that help control, regulate and surveil the use of antibiotics in food-producing 
animals [208,210-212]. Hence, similar to mycotoxins, development of analytic methods that allow for identifying and quantitating a broad spectrum of compounds from a sample, directly contributes to surveillance programs for feedstuff manufacturing (raw materials or feed ingredients, compound feed, and premixes) and, similarly, those commodities derived from food-producing animals.

Table 9 shows a summary of the different characteristics of validated methods for the identification and quantification of veterinary antibiotics in different types of matrices. Molognoni and coworkers, optimized a method for the determination of spectinomycin, halquinol y zilpaterol in compound feed demonstrating once again the capabilities of mass spectrometry to assess two or more families of seemingly unrelated compounds. The authors tried both hydrophilic interaction and reverse-phase chromatography. Though HILIC (Hydrophilic Interaction Liquid Chromatography) offered good results, it requires a longer analysis time (i.e., up to 5 additional min), and is $\mathrm{pH}$ sensitive. Reverse-phase chromatography requires a relatively inexpensive column that is usually available in laboratories and which analytical instrumentation providers generally keep in stock. Additionally, a more effective separation was archived using heptafluorobutyric acid in the mobile phase [202].

Table 9. Measurement techniques meant for veterinary antibiotics in food and feed samples.

\begin{tabular}{|c|c|c|c|c|}
\hline Matrix & $\begin{array}{c}\text { Number of } \\
\text { Analytes/Execution } \\
\text { Time }\end{array}$ & Extraction Method & $\begin{array}{l}\text { Measurement Method, Chromatographic } \\
\text { Column }\end{array}$ & Reference \\
\hline \multicolumn{5}{|c|}{ Recent Multiresidue and Multi-Class Analysis of Antibiotics in Feeds } \\
\hline Rendering products & 40/Not Indicated & $\begin{array}{l}\text { During extraction, fat was removed and } \\
\text { clean up performed using an SPE PRiME } \\
\text { HLB cartridge, eluate evaporated to } \\
\text { dryness and reconstituted with ACN and } \\
\text { formic acid }\end{array}$ & $\begin{array}{l}\text { BEH C }_{18} \text { column } \\
\text { Identification: HPLC-MS/MS/ESI }{ }^{+}\end{array}$ & [201] \\
\hline Compound feed & 3/Not Indicated & Formic acid $/ \mathrm{H}_{2} \mathrm{O}(80: 10)$ & $\begin{array}{l}\text { Hypersil Gold HILIC }(150 \times 3.0 \mathrm{~mm}, 5 \mu \mathrm{m}) \\
\text { and } \mathrm{C}_{18}(50 \times 2.1 \mathrm{~mm}, 3.5 \mu \mathrm{m}) . \\
\text { Identification: } \mathrm{HPLC}-\mathrm{MS} / \mathrm{MS} / \mathrm{ESI}^{+}\end{array}$ & [202] \\
\hline $\begin{array}{l}\text { Pig, poultry, } \\
\text { and cattle feed }\end{array}$ & $62 / 13$ & $\begin{array}{l}\mathrm{ACN} / \mathrm{H}_{2} \mathrm{O}(90: 10) \text { acidified with } \\
\mathrm{CH}_{3} \mathrm{COOH} \text {. }\end{array}$ & $\begin{array}{l}\mathrm{C}_{18} \text { Vensusil XBP }(50 \times 2.1 \mathrm{~mm}, 3.0 \mu \mathrm{m}, \\
100 \AA \text { A }) \text {. Identification: } \mathrm{HPLC}-\mathrm{MS} / \mathrm{MS}_{\mathrm{ESI}^{+}}\end{array}$ & [209] \\
\hline Feed & 10/Not Indicated & $\begin{array}{l}\text { Acidic extraction with hydrochloric acid } \\
\left(0.5 \mathrm{~mol} \mathrm{~L}^{-1} \text { aqueous solution), and }\right. \\
\text { purified by SPE cartridge }\end{array}$ & $\begin{array}{l}\text { Acquity UPLC HSS } \\
\text { T3 }(150 \times 2.1 \mathrm{~mm}, 1.7 \mu \mathrm{m}) \text {. Identification: } \\
\text { HPLC-MS } / \mathrm{MS} / \mathrm{ESI}^{ \pm}\end{array}$ & [213] \\
\hline \multicolumn{5}{|c|}{ Multiresidue Analysis of Antibiotics in Foods } \\
\hline Fish muscle & $41 / 20$ & $\begin{array}{l}\text { Extraction with ammonium formate and } \\
\text { ACN } / \mathrm{H}_{2} \mathrm{O}(80: 20)\end{array}$ & $\begin{array}{l}\text { X-SELECT C } C_{18}(150 \times 2.1 \mathrm{~mm}, 3.5 \mu \mathrm{m}) \\
\text { Identification: HPLC-MS/MS/ESI }{ }^{ \pm}\end{array}$ & [205] \\
\hline Shrimp & $24 / 8$ & $\begin{array}{l}\text { Extraction with formic acid in water } \\
\text { and ACN }\end{array}$ & $\begin{array}{l}\text { XBridge BEH C } 18(100 \times 2.1 \mathrm{~mm}, 2.5 \mu \mathrm{m}) \text {. } \\
{\text { Identification HPLC-MS } / \mathrm{MS} / \mathrm{ESI}^{+}}\end{array}$ & [206] \\
\hline $\begin{array}{l}\text { Poultry muscle tissue } \\
\text { and eggs }\end{array}$ & $14 / 14$ & $\begin{array}{l}\text { ACN extraction } \\
\text { Centrifugation at } 00^{\circ} \mathrm{C} 45 \mathrm{~min}\end{array}$ & $\begin{array}{l}\text { Poroshell } 120 \mathrm{ECC}_{18}(50 \times 3.0 \mathrm{~mm}, 2.7 \mu \mathrm{m}) \\
\text { Identification: HPLC-MS } / \mathrm{MS} / \mathrm{ESI}^{ \pm} \\
\text {(quadrupole linear ion trap) }\end{array}$ & [207] \\
\hline Honey & 6/Not Indicated & $\begin{array}{l}\text { Modified QuEChERS method } \\
\text { Extraction was performed using } \mathrm{ACN} \\
\text { and } \mathrm{MgSO}_{4} \text { and } \mathrm{NaCl}\end{array}$ & $\begin{array}{l}\text { ZORBAX Eclipse XDB C-18 }(150 \times 4.6 \mathrm{~mm} \text {, } \\
5 \mu \mathrm{m}) \text {. Identification: HPLC-MS } / \mathrm{MS} / \mathrm{ESI}^{+}\end{array}$ & [214] \\
\hline
\end{tabular}

\subsubsection{Multiresidue Analysis of Antibiotics in Foods}

Barreto and coworkers developed a method to assay $n=14$ different coccidiostats (i.e., lasalocid A, maduramicin, monensin, narasin, salinomycin, semduramicin, robenidine, diclazuril, toltrazuril, trimethoprim, chlopidol, amprolium, diaveridin y nicarbazin) in poultry muscle tissue and eggs; after testing several chromatographic columns, they selected the one that completed the separation under less time (i.e., $14 \mathrm{~min}$ ). The authors used low temperature clean-up as an alternative to SPE, reducing costs, time and ion suppression. Internal standards where used to compensate intense matrix effects [207]. Regarding aquaculture, Kang and coworkers analyzed $n=41$ antibiotics in fish muscle [205]. Similarly, Kumar Saxena and coworkers developed and validated $n=24$ antibiotics (including quinolones, sulfonamides, and tetracyclines) in shrimp, and they preferred to use methanolic separation [206]. Finally, Shendy and coworkers identified $n=6$ different classes of antibiotics in honey with a modified QuEChERs procedure simultaneously. Extraction was performed using ACN and $\mathrm{MgSO}_{4}$ and $\mathrm{NaCl}$ [214]. 
For both mycotoxins and antibiotics, a review was made of the wide variety of methods used in the food industry for the simultaneous, extraction of multiple analytes. For the identification and quantification of each chemical, a sensitive and selective tool is required. It is here that mass spectrometry has been useful, by reducing costs and response time. [185,202,209].

\subsubsection{Method Application Experience (Mycotoxins and Antibiotics)}

A multitoxin $(n=26)$ analysis was applied to feedingstuffs using, as a reference, a method previously described by Wang and coworkers in cornmeal. ACN $/ \mathrm{CH}_{3} \mathrm{COOH} / \mathrm{H}_{2} \mathrm{O}(74: 1: 25)$ was used for extraction and cleanup we exploited the versatility of HLB cartridges (which allow the retention of a wide array of analytes with the least of interferences) [215]. When compared with immunoaffinity columns, this sorbent is less prone to fracturing and do not require low temperatures for storage. Later, the recovered extract was evaporated to dryness using vacuum at $60{ }^{\circ} \mathrm{C}$ and reconstituted with $\mathrm{MeOH}$. The method relies on the 12.5-fold concentration of the original analyte to improve sensitivity. In the case of antibiotics $(n=23)$, we based our procedure on that described by Duelge and coworkers [216]. We extracted and eluted analytes using an $\mathrm{ACN} / \mathrm{MeOH}$ solution. Again, we trusted the versatility of HLB SPE cartridges during cleanup. Both assays were single quadrupole equipped LC system using $\mathrm{ESI}^{+}$and relied on a reverse phase separation (Zorbax Eclipse Plus, $100 \times 3 \mathrm{~mm}, 3.5 \mu \mathrm{m}$ ). For mycotoxin separation, the mobile phase consisted of a gradient using acidified $(0.1 \mathrm{~mL} / 100 \mathrm{~mL}$ formic acid) $\mathrm{ACN}$ and $\mathrm{H}_{2} \mathrm{O}$. For antibiotics, the gradient consisted of three different acidifed solvents $\mathrm{ACN}, \mathrm{H}_{2} \mathrm{O}$, and $\mathrm{MeOH}$. In our experience, the first two-solvent gradient (starting with water) can separate most antibiotic families ( $\beta$-lactams, tetracyclines, macrolides, streptogramins, lincosamides, aminoglycosides). Our gradient finishes with $\mathrm{MeOH}$ which is the only solvent capable of eluting coccidiostats (e.g., monensin and narasin). Efficient chromatographic separation was achieved under $35 \mathrm{~min}$.

\subsection{Amino Acids}

Protein building blocks (i.e., amino acids), biologically, can be separated into two main groups. Exogenic/essential amino acids (i.e., Arg, Phe, His, Ile, Leu, Lys, Met, Thr, Trp, and Val), are not synthesized by the organism and must be provided in the diet to cover the requirement. The remaining amino acids are endogenic (i.e., Ala, Cys, Asp, Glu, Pro, Ser, Tyr, and Gly). Several of these amino acids (e.g., Lys, Met, Thr, and Trp) are prepared synthetically and are commercially available to use as feed additives. The purity of these additives must be routinely checked and adequately verified. Hence, methodological development is paramount for quality control for determination of amino acids in feed materials and feed mixtures. However, few reports have focused on feed. As a result; we intend to give an overview of the methods available in related matrixes.

\subsubsection{Fish Tissue}

In a comprehensive research article, Mohanty and coworkers reported the complete amino acid profile (except tryptophan which was assessed spectrophotometrically and basic hydrolysis) for 27 different food fishes. [217]. Derivatization was performed using 6-aminoquinolyl- $N$-hydroxysucciminidyl carbamate (AQC), this specific reagent requires neutral $\mathrm{pH}$ to work. Adduct formation has the advantage of being stable and reacting with secondary amines. No variability among profiles was found in fishes of the same species from different locations. They also related the concentration of the amino acid found in the fish with the environment in which they live (e.g., marine and cold-water fishes showed relatively higher amounts of Met). At the same time, they recommend the consumption of certain fish species for several amino acids dietary deficiency in humans [217]. Example of methods suitable to analyze amino acids in diverse matrixes is shown in Table 10. 
Table 10. Sample pretreatment, derivatization and measurement conditions for amino acids in feeds.

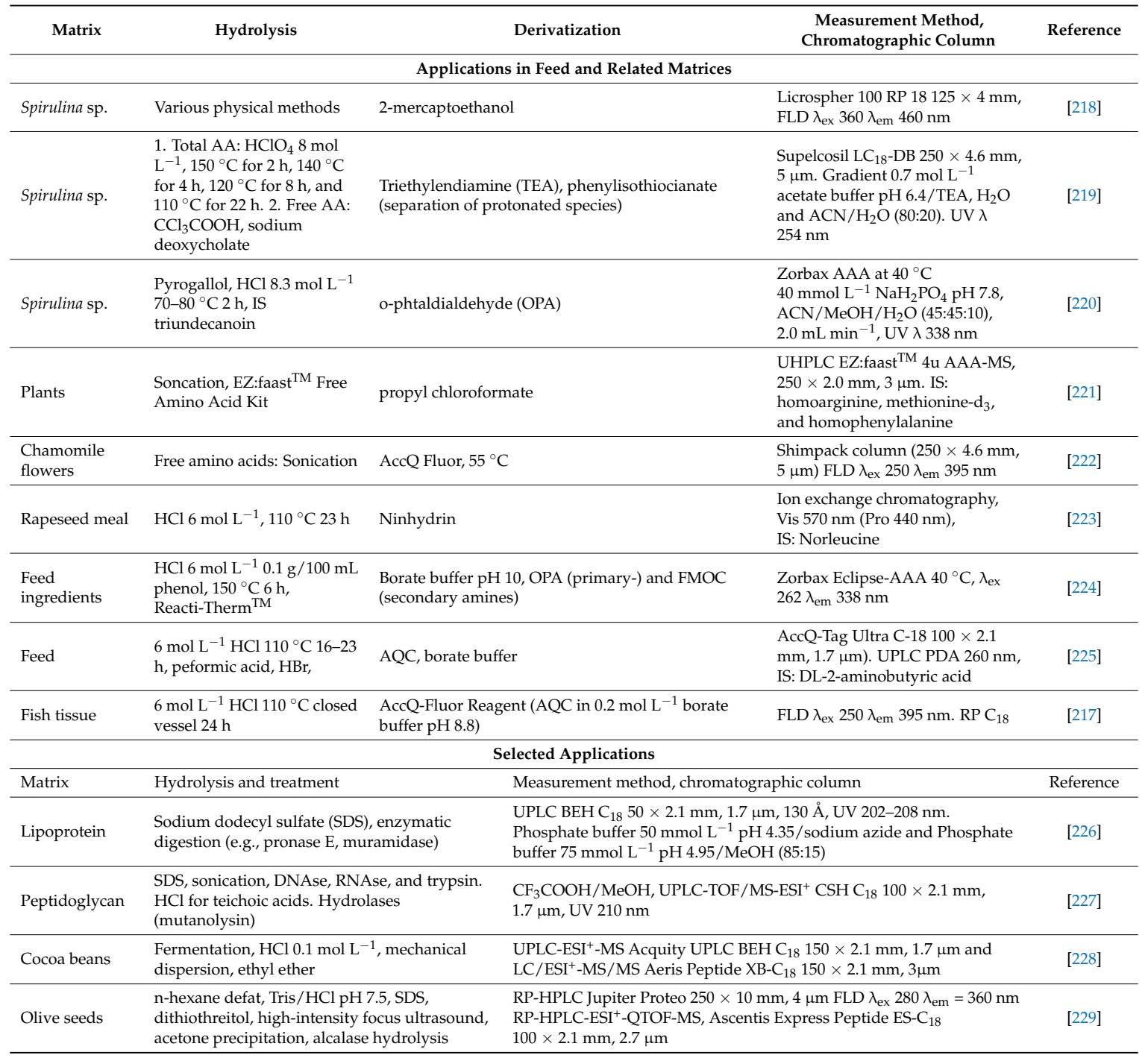

\subsubsection{Filamentous Cyanobacteria, Spirulina sp.}

Spirulina sp. is a filamentous cyanobacterium that have been recognized for its nutritional value as a feed ingredient and supplement, and has been related to health benefits in humans [230]. Its nutrient profile has been reported previously, and it has even exhibited a higher amino acid value (except for Lys, Glu, Pro, His) when compared with that of soybean meal (a staple feed ingredient) [218]. Additionally, based on this profile, they calculated energy for a broiler diet. Nurcahya Dewi and coworkers applied different physical treatments (i.e., drying, sonication 30/60 min, reflux $60 / 90^{\circ} \mathrm{C}$, maceration in $\mathrm{MeOH}$ ) to determine their effects on Spirulina sp. amino acid profile, which they concluded is rich in amino acids related to umami flavor (i.e., Asp and Glu). Drying and methanol maceration showed to be the treatment that delivered the highest $(8.37 \mathrm{~g} / 100 \mathrm{~g})$ and lowest ( $2.34 \mathrm{~g} / 100 \mathrm{~g})$ contents of Glu, respectively [231].

Campanella and coworkers assayed total and free amino acids from Spirulina sp.; they found that freshwater Spirulina contained relatively high concentrations of non-essential amino acids. The authors indicate that the samples tested were lysine-rich and limited in sulfur-containing amino acids. Free amino acids constitute as high as $2 \%$ of the amino acid input. Method-wise, the authors used an oxidation-capable acid, this is chancy as it may contribute to analytes deterioration. Additionally, the mobile phase already included the derivatization agent [219]. 
Al-Dhabi and Arasu quantified polyunsaturated fatty acids, sugars, polyphenol and total and free amino acids in Spirulina sp. In contrast to the authors mentioned above, this research group used pre-column derivatization and a dedicated column for analysis. Total amino acids contents ranged from 11.49 to $56.14 \mathrm{mg} / 100 \mathrm{~g}$; from which essential amino acids accounted for 17.00 to 39.18\%. [220].

\subsubsection{Compound Feedstuff}

For the specific case of feed, a time-reduced (i.e., complete separation in an eight-minute chromatographic run) analysis has been recently developed [225]. AOAC OMA ${ }^{\mathrm{SM}}$ includes two different assays to determine amino acids based on LC; 992.12 design for pet foods using fluorescence and 999.13 include ninhydrin/Orto-phthalaldehyde (OPA) fluorescence or pulsed coulometric detection. Finally, a report made by Wang and coworkers described a successful simultaneous analysis of 20 amino acids without using derivatization using an evaporative light scattering detector [232]. More recently, underivatized amino acids have also been monitored using hydrophilic interaction liquid chromatography coupled with tandem mass spectrometry [233]. Herein, we included some examples of derivatization agents. However, we suggest the reader access a paper written by Masuda and Dohmae, which not only cites the four most commonly used reagents for amino acid derivatization, but also identifies their strengths and weaknesses [234].

\subsubsection{Bacterial Cell Walls, Peptidoglycan, and Food-Extracted Peptides}

A less common application for LC, is to monitor the products from the hydrolysis of bacterial cell walls (using enzymatic physical, and chemical approaches) and posterior fragment analysis. Desmarais and coworkers design a method that included the digestion of Braun's lipoprotein. Muropeptide fragments (monomers-trimers), 3,3-diaminopimelic acid among others [226]. Kühner and coworkers developed a similar application; complete muropeptide hydrolysis was accomplished within $24 \mathrm{~h}$. UPLC/MS was used to monitor fragments. After $\mathrm{BH}_{4}^{-}$reduction, both Gram-positive to Gram-negative bacteria can be evaluated after gradient modification [227]. In this regard, MSD (Mass Spectrometry Detectors) serve as a good reference for additional mass information, which will ease the peptidoglycan in silico reconstitution. This application has not found accommodation in food or feed, but it can correctly be adapted for bioreactions/fermentations or lactic bacteria.

Other applications for LC include, for example, the work by Marseglia and coworkers. They identified $n=44$ different peptides from cocoa beans. The peptide fragmentation pattern in fermented cocoa samples was used to describe the geographic origin, different fermentation levels, and roasting. Vicilin, a storage protein, was identified in cocoa bean samples, information that can be useful to understand the biological activity of cocoa and to determine the aroma relevant peptides [228]. MS assisted analysis is advantageous as amino acids lack any distinctive chromophores and already have readily ionizable moieties. Prados and coworkers recently have described a method to isolate, characterize and identify peptides that can downregulate adipogenesis. The authors also used semipreparative fractionation to achieve the initial peptide separation [229].

\subsubsection{Method Application Experience}

When facing fresh feed products (e.g., wet pet food, forages) additional operation units such as lyophilization is necessary before sample treatment (see, for example, [235]). To obtain individual amino acids, most applications require acid or alkaline hydrolysis. However, amino acids are extremely susceptible to oxygen during hydrolysis, to prevent quantitative losses, we recommend the sample hydrolysis steps suggested elsewhere for furosine [236]. Additionally, pyrogallol in $1 \mathrm{~g} / 100 \mathrm{~mL}$ is also used as a radical receptor (i.e., a radical sink) to avoid amino acid degradation. Particularly, Trp, Thr, and Tyr are usually lost during acid hydrolysis, cysteine is oxidized to cysteic acid, and asparagine and glutamine (if present) will transform to their respective acids. Hydrolysis may be performed using a feed of known concentration in parallel as a reference [237]. 
From the sample preparation standpoint, we have applied a Supelco ENVI-Carb SPE cartridge for cleanup as hydrolysate retain undesired particulates. A translucent extract is obtained after SPE that will be suitable for both FLD (Fluorescence Detector) and UV-Vis (Ultraviolet-Visible) detection-based analysis. Also, cleaner chromatograms are obtained as interferences are significantly reduced. This cartridge will adsorb (including those responsible for coloration) a great range of molecules, while the (charged) amino acids will not be retained. Sodium azide is applied routinely for extract storage. However, best results are obtained when measurements are performed immediately after preparation steps.

We have used a method based on OPA pre-column derivatization adapted from an established method for biopharmaceuticals [238]. We also recommend the strict use of a $C_{18}$ guard column to increase column lifespan. When applied to feed samples and feed ingredients, essential amino acids covered include Arg, His, Ile, Leu, Lys, Met, Phe Val, and non-essential Ala, Asp/Asn, Glx, Cys/CY2, Gly, and Ser for a total of 14 amino acids. OPA derivatization is only effective under alkaline conditions (usually performed using borate buffer $\mathrm{pH}$ 8-10). Therefore, the feed hydrolysate must be neutralized (to $\mathrm{pH}$ 7.0) before injection, as the buffer will not be able to compensate for the $\left[\mathrm{H}_{3} \mathrm{O}^{+}\right]$ that results from the acid treatment. Furthermore, 9-fluorenylmethyl chloroformate (FMOC) must be included during derivatization (additional to OPA) to obtain proline and hydroxyproline amino acids (see, for example, [224]).

Method automatization (when an automatic sampler is available) can concede an advantage since the reaction occurs in situ within the needle. Automated precolumn derivatization is also useful for unstable adducts (e.g., OPA derivatives). A benefit of amino acid derivatization is that most adducts can be monitored using a UV/VWD (Ultraviolet/Variable Wavelength Detector) or DAD/PDA (Diode-Array Detection/Photodiode-Array Detection), so even if the fluorescence detector is not available, analysis can still be performed. Though, the fluorescent detector can filter interferences, begetting cleaner chromatographs. We have also used the same method to assess the purity of feed grade amino acids, and taurine. The technique can also be applied to energy drinks to evaluate taurine in as a very simple "dilute and shoot" method after sonication for sample degassing. Interestingly, ninhydrin and OPA can detect complementary analytes to methods based in ninhydrin (see, for example, [223]).

\subsection{Triphenylmethane Dyes}

Malachite green is a dye usually used in aquaculture as a fungicide and antiparasitic due to its low cost and effectiveness [239]. The widespread use of this substance is not without downsides, though, including residue accumulation in fish tissue and contamination of sediments and water bodies, which can affect non-target organisms downstream (see, for example, [240,241]).

Recent and improved methods have found acceptance to monitor these kinds of dyes in fish tissue. For example, Hidaya and coworkers already conducted a short review on techniques available for detection of malachite and leucomalachite green in the fish industry [242].

Within, this paper, several LC-based techniques are mentioned. Triphenylmethane dyes suffer from reversible redox reactions; each form can be oxidized or reduced to one another (see, for example, [243]; Figure 5). 
<smiles>[R]c1ccc(C(=C2C=CC(=[N+](C)C)C=C2)c2ccc(N(C)C)cc2)cc1</smiles>

Malachite green $\mathrm{R}=\mathrm{H}$; Crrystal violet $\mathrm{R}=\mathrm{N}\left(\mathrm{CH}_{3}\right)$<smiles>[R]c1ccc(C(c2ccc(N(C)C)cc2)C2C=CC(N(C)C)C=C2)cc1</smiles>

Leucmalachite green $\mathrm{R}=\mathrm{H}$; Leucocrystal violet $\mathrm{R}=\mathrm{N}\left(\mathrm{CH}_{3}\right)$<smiles>CCN(CC)c1ccc(C(=C2C=CC(=[N+](CC)CC)C=C2)c2ccccc2)cc1</smiles>

Brilliant Green

Figure 5. Chemical structures for three triphenylmethane dyes which are sharing a common phenyl backbone sharing a methylidyne. Each molecule has extended $\pi$-delocalized electrons justifying their crystal coloration and visible light absorption (ca. $621 \mathrm{~nm}$ for malachite green).

Table 11 shows a summary of various methods for the extraction and identification of malachite green and its metabolites. Although it is a common contaminant in aquaculture production, and research focuses on fresh residues from aquaculture production animals (fish, shrimp, lobster, among others), the development of methods should also be extended to the analysis of feed [244] as fish and shrimp feed are made from marine by-products. Doses on fish or shrimp range from $0.05-0.2 \mathrm{mg}$ $\mathrm{L}^{-1}$ as an active ingredient have been used. Treatments for fish eggs include dosages of $5 \mathrm{mg} \mathrm{L}^{-1}$ is usually suggested for fish tanks. Laboratories usually measure malachite green with equipment able to detect tissue residues below $2 \mu \mathrm{g} \mathrm{kg}^{-1}$ (maximum permitted residue limit in fish tissue; [250]). A very interesting approach was made by Furusawa who developed a green chemistry method for malachite green and its metabolite [251].

Table 11. Measurement techniques meant for triphenylmethane dyes.

\begin{tabular}{|c|c|c|c|}
\hline Matrix & Extraction Method & $\begin{array}{l}\text { Measurement Method, } \\
\text { Chromatographic Column }\end{array}$ & Reference \\
\hline Fresh fish muscles & $\begin{array}{l}\text { Extraction with } 0.1 \mathrm{~mol} \mathrm{~L}^{-1} \mathrm{NH}_{4} \mathrm{O}_{2} \mathrm{C}_{2} \mathrm{H}_{3} \\
\text { buffer, } \mathrm{pH} 4.5 \text {, HAH solution } 0.25 \mathrm{~g} \mathrm{~mL}^{-1} \\
1 \mathrm{~mol} \mathrm{~L} \\
\end{array}$ & $\begin{aligned} \text { LC: } & \text { Cloversil-C } 18 \text { } 250 \times 4.6 \mathrm{~mm}, 5 \mu \mathrm{m} . \\
& \text { Identification: } \mathrm{MS} / \mathrm{MS} / \mathrm{ESI}^{+}\end{aligned}$ & [243] \\
\hline Channel Catfish muscle & $\begin{array}{l}\text { Extraction with Mcllvaine buffer, TSA, and } \\
\text { TMPD. Oasis MCX SPE columns }\end{array}$ & $\begin{array}{c}\text { LC: Prodigy ODS- } 3 \mathrm{C}_{18} 150 \times 4.6 \mathrm{~mm}, \\
3 \mu \mathrm{m} \text {. Identification: } \mathrm{MS} / \mathrm{MS} / \mathrm{ESI}^{+}\end{array}$ & [244] \\
\hline Aquaculture water & Not indicated & $\begin{array}{l}\text { LC: Phenomenex } C_{18} 140,250 \times 4.6 \mathrm{~mm}, 5 \\
\mu \mathrm{m} \text {. Identification: UV } 558 \mathrm{~nm} \text { (malachite } \\
\text { green and crystal violet), FLD } \lambda_{\mathrm{ex}} 265, \lambda_{\mathrm{em}} \\
\quad 360 \mathrm{~nm} \text { (leuco forms) }\end{array}$ & [245] \\
\hline Processed fish products & $\begin{array}{l}\text { Extraction with ammonium acetate buffer, } \\
\text { HAH solution, p-TsOH solution, and can }\end{array}$ & $\begin{array}{c}\text { LC: } 250 \times 4.6 \mathrm{~mm}, 5 \mu \mathrm{m} \text { Capcell PAK } \mathrm{C}_{18} \\
\text { Identification: MS } / \mathrm{MS} / \mathrm{ESI}^{+}\end{array}$ & [246] \\
\hline Fish tissue & $\begin{array}{l}\text { Modified QuEChERS Extraction: } \\
\qquad \mathrm{NH}_{4} \mathrm{O}_{2} \mathrm{CH} \text { and can }\end{array}$ & LC: XCharge $\mathrm{C}_{18}$ column & [247] \\
\hline Salmon & $\begin{array}{c}\text { Extraction } \mathrm{C}_{2} \mathrm{H}_{3} \mathrm{O}_{2}{ }^{-} \text {buffer, p-TSA solution, } \\
\text { hydroxylamine and can }\end{array}$ & $\begin{array}{l}\text { YMC phenyl 3-4-5 } 50 \times 4.0 \mathrm{~mm}, 3 \mu \mathrm{m} \\
\text { Identification: } \mathrm{LC}-\mathrm{MS} / \mathrm{ESI}^{+} / \mathrm{APCI}\end{array}$ & [248] \\
\hline Fish feed & Extraction with $\mathrm{ACN} / \mathrm{CH}_{3} \mathrm{OH} / \mathrm{CH}_{3} \mathrm{COOH}$ & $\begin{array}{c}\text { Chromolith }^{\circledR} \text { Performance RP-18e } \\
(100 \times 4.6 \mathrm{~mm}) \text { Identification: } \\
\text { MS } / \mathrm{MS} / \mathrm{ESI}^{+}\end{array}$ & [249] \\
\hline
\end{tabular}

As previously mentioned, Wang and coworkers used solid-phase microextraction with the excellent result to assess malachite green, crystal violet and their respective metabolites using a monolithic fiber [245]. Bae Lee and coworkers homogenized fish tissue samples, and the extracted residues were partitioned into dichloromethane and an in situ oxidation with 2,3-dichloro-5,6-dicyano-1,4-benzoquinone. Afterward, cleaned-up was performed on neutral alumina and propyl sulfonic acid cation-exchange solid-phase extraction cartridges. Malachite green and crystal violet were determined at 618 and $588 \mathrm{~nm}$ using HPLC-Vis detector [246]. A common approach included analyzing dyes using traditional detectors and adding a step that included confirmation by 
MS. Chengyun and coworkers relied on Oasis ${ }^{\circledR}$ MCX (a strong cation exchange-based adsorbent) to perform clean-up. After a two-step, QuEChERS extraction, dispersive solid phase extraction coupled with, both, a reverse phase and strong anion exchange (as well as a mixed mode adsorbent) cleanup was tested. Residues of the dyes were evaluated in codfish [247]. However, we do not see how anion exchange favors dye-stationary phase interaction, since all parent compounds are positively charged. Noteworthy, usually reverse phase columns can resolve these types of dyes with ease, even if several analytes are to be evaluated simultaneously. Croatia and Iran are specific examples of countries which have stated have found residues of this dye in fish tissue [252,253]. Both cases demonstrate the need to assess these compounds in food items. However, both research groups used immunoassays to evaluate the contaminant. AOAC method $\mathrm{OMA}^{\mathrm{SM}} 2012.25$ is a reference based on LC-MS/MS to assess triphenylmethane dyes and their metabolites in aquaculture products.

Additionally, US FDA reference method is based on the isolation of malachite green using alumina/propyl sulfonic solid phase extraction cartridges previous to Non-Discharge Atmospheric Pressure Chemical Ionization and an LC-MS ${ }^{n}$; quantification was performed in salmon [248]. Finally, since fish and shrimp compound feed can also be based in aquaculture by-product meal, as a source of protein, contaminated tissue can reach the final product. Hence, the need for feed analysis is evident, as it shows, Abro and coworkers [249].

\section{The Common Ground among Measurements Performed in Food and Feed Laboratories}

\subsection{Nitrates and Nitrites}

Nitrates and nitrites are natural compounds that are part of the nitrogen cycle, but especially high dosages of these ions are registered because of anthropological activities [254,255]; they enter human diets by means of drinking water, leafy vegetables, and cured meats. Noteworthy, these ions have been authorized as additives in several countries including the European Community [256,257].

Though there is evidence that both ions have a relevant biological and physiological function, special attention has been paid to nitrates and nitrites and their metabolites such as $\mathrm{N}$-nitrosamines and nitrous oxide as all these molecules may pose a health hazard [256,257]. For example, these compounds have been related to colorectal cancer [256-261]. Hence, risk management and assessment in food have been proved necessary [258]. Regarding the quantification of $\mathrm{NO}_{2}{ }^{-}$and $\mathrm{NO}_{3}{ }^{-}$using $\mathrm{HPLC}$, there are two main approaches used i.e., ion exchange and reverse phase columns (Table 12).

\subsubsection{Ion Exchange Chromatography}

When analyzing crops, one must consider that cultivar, and harvest date can affect the nitrate levels of selected vegetables. Hence, maximum levels have been set by European legislation accordingly [262]. For example, Brkić and coworkers analyzed several leafy greens $(n=200)$ in two different seasons, in order to evaluate differences in ion content and encountered considerable differences among vegetable and sampling season [263]. Pardo-Marin and coworkers assessed vegetable-based baby foods, considering the levels found within these types of foods. They calculated ion ingestion between 13-18\% of the acceptable daily intake for an infant. [264]. Quijano and coworkers assessed the nitrate content of vegetables $(n=533)$; they obtained values up to $3509 \mathrm{mg} \mathrm{kg}^{-1}$ in chard samples. They calculated an intake of $490 \mathrm{mg} \mathrm{kg}^{-1} \mathrm{bw} \mathrm{day}^{-1}$ for a young population, values which tend to increase the risk of exceeding acceptable intake values [265]. The main advantages in using ion exchange columns are that the separation can be accomplished using aqueous buffers which are made up from relatively cheap salts, making the methods apt for green chemistry and avoid mobile phase drift [263].

\subsubsection{Ion Pairing and Reverse Phase Chromatography}

Tetrabutylammonium salt has also been used as an ion-pairing agent coupled with reverse phase columns (Table 12). For example, Hsu and coworkers used a reverse phase approach to 
assess both ions in cured meats and vegetables. The authors found the highest values of $\mathrm{NO}_{3}{ }^{-}$ in spinach (4849.6 mg kg${ }^{-1}$ ) and for $\mathrm{NO}_{2}{ }^{-}$in hot dogs $\left(78.6 \mathrm{mg} \mathrm{kg}^{-1}\right)$ [266]. Nitrite tends to oxidate to $\mathrm{NO}_{3}{ }^{-}$, the authors cite several factors affecting nitrate and nitrite recovery in foods (e.g., temperature, $\mathrm{pH}$, metals). Usually, non-desired compounds found in greens differ from those found in meat products, for which proteins interfere significantly. Meat sample extracts will need $\mathrm{pH}$ adjustments and higher temperatures are needed to improve recovery. Some of these parameters must be monitored during analysis, especially when vegetables are subject of study [266]. Croituru used a similar approach to assess human, rabbit, rat urine as well as vegetables. However, they roduced adducts (an azo dye, $\mathrm{HO}_{3} \mathrm{SC}_{6} \mathrm{H}_{4}-\mathrm{N}=\mathrm{N}-\mathrm{C}_{10} \mathrm{H}_{6} \mathrm{NH}_{2}$ ) based on Greiss reaction (sulfanilic acid form a diazonium cation $\left(\mathrm{HO}_{3} \mathrm{SC}_{6} \mathrm{H}_{4}-\mathrm{N} \equiv \mathrm{N}^{+}\right)$with $\mathrm{NO}_{2}{ }^{-}$and then with 1-naphthylamine) for $\mathrm{NO}_{2}{ }^{-}$ that was measured at $520 \mathrm{~nm}[267,268]$. Interestingly, the authors followed the reaction with mass spectrometry. We encourage the reader to pay special attention to this paper as highlights difficulties during method development. The author concluded that while useful, the use of Greiss reaction, spectrophotometrically, is unadvisable as several samples may exhibit additional confounding compounds that may behave similarly as the $\mathrm{NO}_{2}{ }^{-}$ion adduct. However, is quite valuable as a derivatizing agent when coupled with HPLC; the method can work with samples of different origins without the need for further modifications [267]. Samples were decolorized with carbon and $\mathrm{ZnSO}_{4}$ was applied for protein precipitation to overcoming this matrix interference and enhance the sensitivity. Croituru and coworkers used a validated method to assess $\mathrm{NO}_{2}{ }^{-}$and $\mathrm{NO}_{3}{ }^{-}$in vegetables for self-consumption; toxicologically speaking, the $\mathrm{NO}_{2}{ }^{-}$content found in the samples was deemed too low to represent a hazard [269].

Stationary phases containing only alkyl chains have been used, but it is also possible to find mixed stationary phases, for example, Abdulkair and coworkers assayed $\mathrm{NO}_{2}{ }^{-}$and $\mathrm{NO}_{3}{ }^{-}$using a stationary phase containing both alkyl groups and phenyl groups (Table 12) to separate both ions successfully after sonication [270].

Chou and coworkers assessed both ions in vegetables and observed a high concentration variability was observed which reflect differences in environmental conditions [271]. The authors also optimized critical chromatographic parameters such as $\mathrm{pH}$, organic solvent fraction, and flow [271]. In this regard, the methanol fraction optimization was demonstrated to be paramount to improve octylammonium solubility and achieve an optimal resolution between both ions. In contrast, $\mathrm{pH}$ and flow variations tend to have an effect only on chromatographic run times and not so much in resolution. 
Table 12. Common chromatographic approaches for the determination of nitrate and nitrite ion.

\begin{tabular}{|c|c|c|c|c|}
\hline Matrix & \multicolumn{2}{|c|}{ Mobile Phase Composition } & $\begin{array}{l}\text { Measurement Method, } \\
\text { Chromatographic Column }\end{array}$ & Reference \\
\hline \multicolumn{5}{|c|}{ Ion Exchange Chromatography } \\
\hline Leafy greens & \multicolumn{2}{|c|}{$10 \mathrm{~g} \mathrm{~L}^{-1}$ of $\mathrm{KH}_{2} \mathrm{PO}_{4}, \mathrm{pH} 3.0$} & $\begin{array}{l}\text { Waters IC-PAK HC anion exchanger } \\
(150 \times 4.6 \mathrm{~mm}), \mathrm{UV} \lambda 214 \mathrm{~nm}\end{array}$ & [263] \\
\hline Baby foods & \multicolumn{2}{|c|}{ Phosphate $5 \mathrm{mmol} \mathrm{L}^{-1}(\mathrm{pH} 6.5)$} & $\begin{array}{l}\text { Waters IC-PAK HC anion exchanger } \\
(150 \times 4.6 \mathrm{~mm}), \mathrm{UV} \lambda 214 \mathrm{~nm}\end{array}$ & [264] \\
\hline Vegetables & \multicolumn{2}{|c|}{ Phosphate $5 \mathrm{mmol} \mathrm{L}^{-1}(\mathrm{pH} 6.5)$} & $\begin{array}{l}\text { Waters IC-PAK HC anion exchanger } \\
150 \times 4.6 \mathrm{~mm}, 10 \mu \mathrm{m}, \mathrm{UV} \lambda 214 \mathrm{~nm}\end{array}$ & [265] \\
\hline \multicolumn{5}{|c|}{ Reverse Phase Chromatography } \\
\hline Matrix & Ion pair reagent & Mobile phase composition & $\begin{array}{l}\text { Measurement method, } \\
\text { chromatographic column }\end{array}$ & Reference \\
\hline $\begin{array}{l}\text { Cured meat and } \\
\text { vegetables }\end{array}$ & $\begin{array}{l}\text { Tetrabutyl } \\
\text { ammonium (TBA) }\end{array}$ & $\mathrm{MeOH}: \mathrm{H}_{2} \mathrm{O}(75: 25)$ & $\begin{array}{l}\text { Phenomenex } C_{18} 110 \AA \text { Gemini } \\
250 \times 4.6 \mathrm{~mm}, 5 \mu \mathrm{m} . \text { PDA } \lambda 214 \mathrm{~nm}\end{array}$ & [266] \\
\hline Vegetables & $\begin{array}{l}\text { TBA, Greiss } \\
\text { reagent }\end{array}$ & $\begin{array}{l}\text { Gradient } \\
\mathrm{MeOH} / \mathrm{ACN} / \mathrm{H}_{2} \mathrm{O}\end{array}$ & $\begin{array}{l}\text { X Bridge } C_{18}, 50 \times 2.1 \mathrm{~mm}, 2.5 \mu \mathrm{m} . \\
\text { UV-Vis } \lambda 222 \text { (nitrate) and } 520 \mathrm{~nm} \\
\text { (nitrite) }\end{array}$ & [267] \\
\hline Cured meats & $3 \mathrm{mmol} \mathrm{L}^{-1} \mathrm{TBA}$ & $\begin{array}{l}\mathrm{ACN} / 2 \mathrm{mmol} \mathrm{L}{ }^{-1} \\
\mathrm{HPO}_{4}{ }^{2-} \mathrm{pH} 4\end{array}$ & $\begin{array}{l}\text { RP-thermophenyl hexyl, } \\
150 \times 4.6 \mathrm{~mm}, 3 \mu \mathrm{m}, \mathrm{UV} \lambda 205 \mathrm{~nm}\end{array}$ & [270] \\
\hline Vegetables & $\begin{array}{l}0.1 \mathrm{~mol} \mathrm{~L}^{-1} \text { octyl } \\
\text { ammonium salt }\end{array}$ & $\begin{array}{l}\text { OA buffer } \mathrm{pH} 7.0 / \mathrm{MeOH} \\
(70: 30)\end{array}$ & $\begin{array}{l}\text { Phenomenex Luna } C_{18} 250 \times 4.6 \mathrm{~mm} \text {, } \\
5 \mu \mathrm{m}, \mathrm{UV} \lambda 213 \mathrm{~nm}\end{array}$ & [271] \\
\hline $\begin{array}{l}\text { Dried vegetables } \\
\text { and water }\end{array}$ & $\begin{array}{l}\text { Triethylamine } \\
\text { (TEA) }\end{array}$ & $\begin{array}{l}\mathrm{C}_{6} \mathrm{H}_{13} \mathrm{SO}_{3} \mathrm{H}, \mathrm{H}_{2} \mathrm{PO}_{4}^{-}{ }^{-} \\
\text {TEA pH 3.0/MeOH (80:20) }\end{array}$ & $\begin{array}{l}\mathrm{C}_{13} 250 \times 4.6 \mathrm{~mm}, 5 \mu \mathrm{m}, \mathrm{UV} \lambda \\
222 \mathrm{~nm} .\end{array}$ & [272] \\
\hline Ham & n-octylamine/TBA & $\begin{array}{l}0.01 \mathrm{~mol} \mathrm{~L}^{-1} \\
\text { n-octylamine } / 5 \mathrm{mmol} \mathrm{L}^{-1} \\
\text { TBA pH } 6.5\end{array}$ & $\begin{array}{l}\text { Acclaim }^{\mathrm{TM}} \text { Polar Advantage and } \mathrm{C}_{18} \\
\text { Thermo Scientific }^{\mathrm{TM}} \text {, HyPURITY } \\
250 \times 4.6 \mathrm{~mm}, 5 \mu \mathrm{m}\end{array}$ & [273] \\
\hline
\end{tabular}

\subsubsection{Miscellaneous Methods for Nitrates and Nitrites}

In contrast with ion pairing approaches, dos Santos and coworkers developed a method based on the reaction of the $\mathrm{NO}_{2}{ }^{-}$with 2,3-diaminonaphthalene to yield a highly specific fluorescent 2,3-naphthotriazole adduct ( $\lambda_{\mathrm{ex}} 375 \lambda_{\mathrm{em}} 415 \mathrm{~nm}$ ), under acidic conditions, to assess the ions in beetroot [274]. Cassanova and coworkers have developed an application for HPLC derivatization based on $\mathrm{VCl}_{3}$, 4-nitroaniline, methanesulfonic acid, and $\mathrm{N}$-(1-naphthyl)-ethylenediamine. Under these conditions, a post-column reduction of nitrate to nitrite can be accomplished [275].

\subsubsection{Method Application Experience}

The preferred methodology used in our laboratories is based on the chromatographic determination of $\mathrm{NO}_{2}{ }^{-}$and $\mathrm{NO}_{3}{ }^{-}$anions simultaneously. Reverse phase (using a $\mathrm{C}_{18}$ column, i.e., Zorbax Eclipse $5.0 \mu \mathrm{m}, 4.6 \mathrm{~mm} \times 150 \mathrm{~mm}$, set at $30^{\circ} \mathrm{C}$ and $0.6 \mathrm{~mL} \mathrm{~min}{ }^{-1}$ ) HPLC-PDA or -VWD (213 $\mathrm{nm}$ as the absorption spectra maximum) is sufficient to perform the assay [266,271]. It is important to emphasize that for the detection and separation of inorganic anions, in this case $\mathrm{NO}_{3}{ }^{-}$and $\mathrm{NO}_{2}{ }^{-}$, the mobile phase must contain a complementary counter ion that interacts with it and with the bonded stationary phase of the column concurrently. In the absence of the counter ion, no interaction with the column is achieved and, as a result, no retention will be obtained at all, as the ions would come out in the void. In this scenario, a tetrabutylammonium salt (e.g., tetrabutylammonium hydrogen sulfate, TBAHS, 155837 Sigma-Aldrich) is a possibility (Figure 6B). In this case, the four alkyl chains from the reagent interact with the eighteen-carbon alkyl chains of the stationary phase and, at the same time, with the $\mathrm{NO}_{2}{ }^{-} / \mathrm{NO}_{3}{ }^{-}$. The elution order may be explained by considering a more delocalized negative charge (among three oxygen atoms) in $\mathrm{NO}_{3}{ }^{-}$and the bent geometry of $\mathrm{NO}_{2}{ }^{-}$due to the nitrogen atom-containing an electron lone pair. Interestingly, $\mathrm{NO}_{2}{ }^{-}$is a larger anion $(0.192 \mathrm{~nm})$, when hydrated, than $\mathrm{NO}_{3}{ }^{-}(0.179 \mathrm{~nm})$ [276]. Now, depending on the length of the column, the affinity of the this will not be sufficient to resolve peaks from the solvent front (specially the first peak; $\mathrm{NO}_{2}{ }^{-}$), this issue is easily solved including acetonitrile in the mobile phase, using slower flows, a longer column or even an ion pair agent with longer alkyl chains (e.g., octylamine). The mobile phase used is $20 \%$ acetonitrile, 
$80 \%$ TBAHS $5 \mathrm{mmol} \mathrm{L}^{-1}$, at a $6.5 \mathrm{pH}$. Interestingly, when injecting a solution with both ions present and at the same concentration, the response (the signals obtained), is very similar in area/height and, as such, sensitivity is very close for both anions.
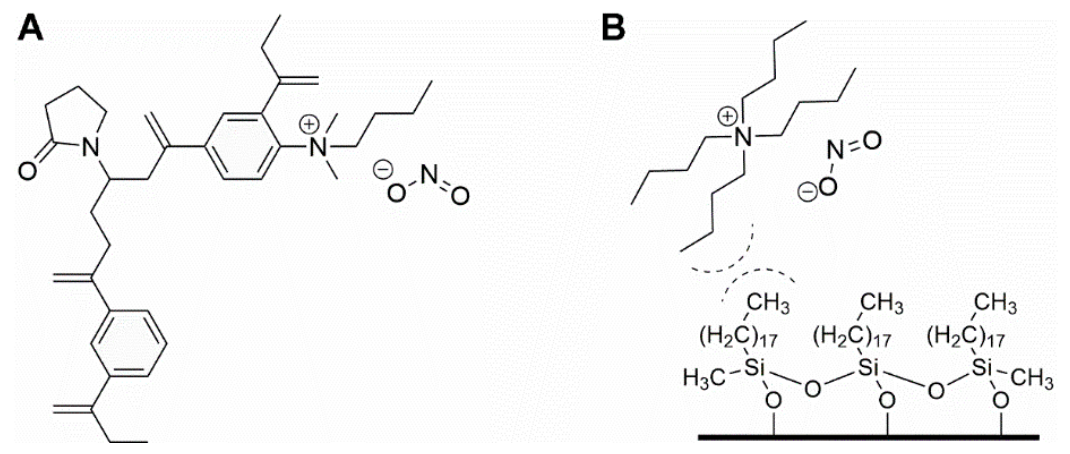

Figure 6. Schematic representation for the interaction of nitrite ion with (A) a cation exchange stationary phase or (B) interaction with TBAHS present in the mobile phase and stationary phase $C_{18}$.

The same methodology has been used in feed to assay hay samples (Figure 7A,B) that were presumed as the source of intoxication in horses [277]. In this case, from ten samples assayed, three (average concentrations of $92.77 \pm 60.88 \mathrm{mg} \mathrm{kg}^{-1}$ ) and six (average concentrations of $92.13 \pm 47.55 \mathrm{mg} \mathrm{kg}^{-1}$ ) samples tested positive for $\mathrm{NO}_{2}{ }^{-}$and $\mathrm{NO}_{3}{ }^{-}$, respectively (unpublished data). Forage and swine compound feed samples $(n=10)$ have also been assayed with this method obtaining values from $<5$ to 23.69 and 2.30 to 4.96 and 925.15 to 1135.10 and 989.51 to $1479.71 \mathrm{mg} \mathrm{kg}^{-1}$ for $\mathrm{NO}_{2}^{-}$ and $\mathrm{NO}_{3}{ }^{-}$, respectively on both accounts. In the case of feeds and fish meals, which suffer from severe matrix effects, SPE has been applied, with good results, as a cleanup and concentration step. Specifically, Oasis ${ }^{\circledR}$ MAX cartridges, conditioned with $2 \mathrm{~mL}$ methanol, and $4 \mathrm{~mL}$ water, load $1 \mathrm{~mL}$ sample, wash $3 \times 1 \mathrm{~mL}$ water, elute with $2 \mathrm{~mL} 0.5 \mathrm{~mol} \mathrm{~L}^{-1} \mathrm{NaCl}$ solution. Chromatograms improve drastically when the elution from the cartridge is performed using the mobile phase.
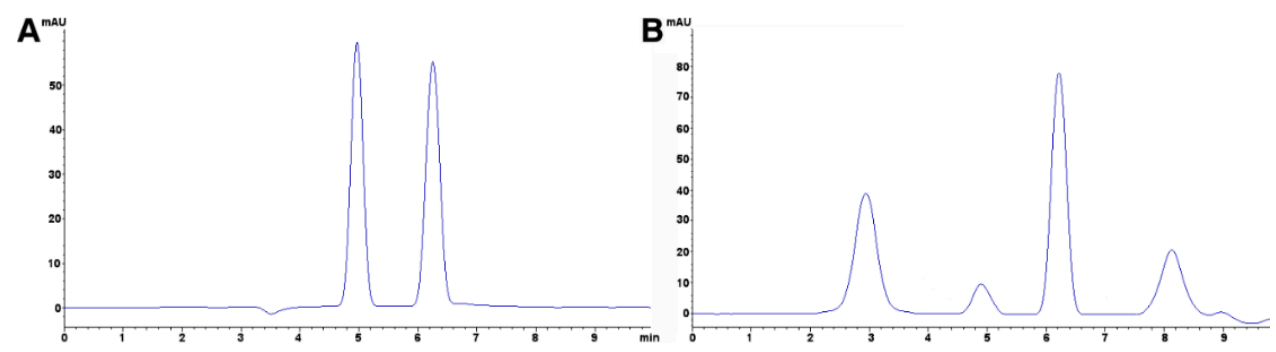

Figure 7. Chromatograph of (A) an aqueous $10 \mathrm{mg} \mathrm{L}^{-1}$ nitrite (4.95 $\left.\mathrm{min}\right)$ and nitrate $(6.26 \mathrm{~min})$ standard (B) hay sample after extraction with hot water, SPE cleanup, and micropore filtration presence of nitrite (4.91 $\mathrm{min})$ and nitrate $(6.23 \mathrm{~min})$ is evident.

\subsubsection{Legislation}

Regulation 2002/EC/32 sets limits for $\mathrm{NO}_{2}{ }^{-}$in fish meal (i.e., $60 \mathrm{mg} \mathrm{NaNO}_{2} \mathrm{~kg}^{-1}$ ) and complete feedingstuffs (i.e., $15 \mathrm{mg} \mathrm{NaNO}_{2} \mathrm{~kg}^{-1}$ ) excluding those intended for pets except birds and aquarium fish. We refer the reader to two thorough reviews that tackle regulatory as well as methodological topics $[278,279]$.

\subsection{Carotenoids}

Chemically, carotenoids are conjugated hydrocarbons that may be further classified as carotenes (without any oxygen molecules) and xanthophylls (with one or more oxygen molecules). Carotenoids are widespread natural pigments, are recognizable from the bright colors (yellow, orange, 
red, or purple) that they often confer on plant and animal organ. The molecules responsible for producing said coloration must be attained from dietary sources. For example, lutein and zeaxanthin are carotenoid pigments that impart yellow or orange color to various common foods such as cantaloupe, pasta, corn, carrots, orange/yellow peppers, fish, salmon and eggs, $\beta$-carotenoid and isomer are found in sweet potatoes, dark leafy greens, butternut squash, lettuce, red bell peppers, apricots, broccoli, and peas, and lycopene are in tomato. As molecules with a conjugated double bond system, carotenoids serve several physiological functions (e.g., antioxidants, immunostimulants, photoprotection, visual tuning, among others). This electron delocation causes them to be particularly unstable compounds, especially sensitive to light, heat, oxygen, and acids. Hence, several precautions have been taken while extracting carotenoids. For example, must be carried out in dim lighting; use rotary evaporation at low temperature and reduced pressure also it has to be carried out under a stream of nitrogen. Finally, samples should be stored in the dark, at about $-20^{\circ} \mathrm{C}[280,281]$.

Carotenoids are fat soluble but, because of the high moisture content of plant tissues, a preliminary extraction solvent miscible with water (e.g., methanol or ethanol) is generally necessary to allow for penetration of the extraction solvent.

Saponification is required to remove interference as neutral fats, chlorophylls, and chlorophyll derivatives. Usually, this procedure is carried out with potassium hydroxide in methanol. Then, it is necessary to perform liquid-liquid extraction using a water-immiscible solvent (e.g., ethyl acetate, ethyl ether, hexane) to obtain the unsaponifiable fraction, where carotenoids should be present. [280-298]. The identification and quantification require high-resolution techniques; the reversed-phase high-performance liquid chromatography has been used routinely to determine carotenoids because of its satisfactory separation efficiency. So, several factors must be evaluated to employ HPLC technique such as column type, mobile phase, chromatographic conditions. Several methods for carotenoid analysis are summarized in Table 13.

Regarding column type, the analysis can be performed using a $\mathrm{C}_{18}$ column. However, $\mathrm{YMC}_{30}$ Carotenoid dedicated column provides excellent results, had better resolution than a $\mathrm{C}_{18}$ column for separation of carotenoids and their geometric isomers. The thirty-carbon alkyl chains interaction with the carotenoid lipophilic profile guarantee less peak distortion and better resolution $[280,281]$. Compounds such as $\alpha / \beta / \gamma / \delta / \varepsilon$-carotene, lutein, zeaxanthin, $\beta$-cryptoxanthin, dehydrolutein, anhydrolutein, astaxanthin, galloxanthin, $\alpha$-doradexanthin, adonirubin, and canthaxanthin can all be separated using the aforementioned chromatographic column.

According to Huck and coworkers, the flow rate did not significantly influence the resolution, but it is essential to use an adequate flow to generate acceptable column back pressure. Also, they studied the effect of column temperature on the separation of lutein, zeaxanthin, $\beta$-cryptoxanthin, and $\beta$-carotene. The column temperature was varied between 21 and $80^{\circ} \mathrm{C}$; the best selectivity being achieved at $21^{\circ} \mathrm{C}$, at a temperature of $34^{\circ} \mathrm{C}$, zeaxanthin could not be easily separated from lutein. The authors concluded that maintaining a constant temperature during carotenoid analysis is critical as small changes in the ambient temperature can cause significant changes in the chromatographic selectivity of the carotenoids and at temperatures higher than $60^{\circ} \mathrm{C}$, the investigated carotenoids unstable.

In the case of the mobile phase, the same authors indicated that carotenoid selectivity was better using tetrahydrofuran, rather than ethyl acetate, and also better than $\mathrm{MeOH}$ and $\mathrm{ACN}$. Carotenoids are sensitive to degradation on the stationary phase of the column by the presence of silanol groups. 
Table 13. Common chromatographic approaches for the determination of carotenoids.

\begin{tabular}{|c|c|c|c|}
\hline Matrix & Extraction Method & $\begin{array}{l}\text { Measurement Method, } \\
\text { Chromatographic Column }\end{array}$ & Reference \\
\hline $\begin{array}{l}\text { Camu-camu (Myrciaria dubia } \\
\text { (Kunth) Macvaugh) }\end{array}$ & $\begin{array}{l}\text { Extracted from the crushed peel with acetone } \\
\text { transferred to petroleum ether/diethyl ether and } \\
\text { saponified with } 10 \% \mathrm{KOH} \text { methanolic }\end{array}$ & $\begin{array}{l}\text { HPLC-PDA } \\
\text { Quantitative: } \mathrm{C}_{18} \text { Nova-Pak ODS } 300 \times 3.9 \mathrm{~mm} \text {, } \\
4 \mu \mathrm{m} \text { set at } 29^{\circ} \mathrm{C} \text {, mobile phase ACN } / \mathrm{H}_{2} \mathrm{O} / \text { ethyl } \\
\text { acetate For Qualitative: } \mathrm{C}_{30} \text { YMC Carotenoid } 250 \\
\times 4.6 \mathrm{~mm}, 3 \mu \mathrm{m} \text { at } 33^{\circ} \mathrm{C} \text {. Mobile phase } \\
\mathrm{MeOH} / \mathrm{MTBE} \text { (methyl tert-butyl ether) }\end{array}$ & [282] \\
\hline $\begin{array}{l}\text { Algae species, Chlorella vulgaris, } \\
\text { and Scenedesmus regularis }\end{array}$ & $\begin{array}{l}\text { Extraction with n-hexane-EtOH-acetone-toluene } \\
(10: 6: 7: 7) 1 \mathrm{~h} \text {, Saponification: } 40 \mathrm{~g} / 100 \mathrm{~mL} \\
\text { methanolic } \mathrm{KOH} \text { at } 25^{\circ} \mathrm{C} \text { in the dark for } 16 \mathrm{~h}\end{array}$ & $\begin{array}{l}\text { PDA, YMC Carotenoid }(250 \times 4.6 \mathrm{~mm}, 5 \mu \mathrm{m}, \\
\mathrm{MeOH} / \mathrm{ACN} / \mathrm{H}_{2} \mathrm{O}(84: 14: 2) \text { and } \mathrm{CH}_{2} \mathrm{Cl}_{2} \text { gradient } \\
\mathrm{UV} \lambda 450 \mathrm{~nm}\end{array}$ & [284] \\
\hline $\begin{array}{l}\text { Tissues of a species of colored bird } \\
\text { (Taeniopygia guttata) }\end{array}$ & $\begin{array}{l}\text { Plasma and liver extract: } \mathrm{n} \text {-hexane:MTBE }(1: 1) \\
\text { Adipose tissue, retina, beak, legs: Saponification } \\
0.02 \mathrm{~mol} \mathrm{~L}^{-1} \text { methanolic } \\
\mathrm{KOH} \text { for } 6 \mathrm{~h} \text {, organic solvent extraction }\end{array}$ & $\begin{array}{l}\text { PDA, YMC Carotenoid } 250 \times 4.6 \mathrm{~mm}, 5 \mu \mathrm{m}, \\
\text { MeOH: } \mathrm{ACN}: \mathrm{CH}_{2} \mathrm{Cl}_{2} \text { linear gradient) }\end{array}$ & [285] \\
\hline $\begin{array}{l}\text { Taiwanese sweet potatoes (Ipomoea } \\
\text { batatas (L.) Lam.) }\end{array}$ & $\begin{array}{l}\text { Extraction with hexane/acetone/EtOH }(2 / 1 / 1) \\
\text { containing } \mathrm{MgCO}_{3} \text { and } \mathrm{BHT} \text { (butylated } \\
\text { hydroxytoluene) by } 0.5 \mathrm{~h} \text {, Saponification with } \\
40 \mathrm{~g} / 100 \mathrm{~mL} \text { methanolic } \mathrm{KOH} \text { for } 3 \mathrm{~h} \text { under } \\
\text { nitrogen gas at } 25^{\circ} \mathrm{C}\end{array}$ & $\begin{array}{l}\text { PDA, YMC Carotenoid } 250 \times 4.6 \mathrm{~mm}, 5 \mu \mathrm{m}, \\
\text { at } 25^{\circ} \mathrm{C}, \mathrm{MeOH}-\mathrm{ACN}-\mathrm{H}_{2} \mathrm{O}(84: 14: 2) \text { and } \mathrm{CH}_{2} \mathrm{Cl}_{2} \\
\mathrm{UV} \lambda 450 \mathrm{~nm}\end{array}$ & [287] \\
\hline $\begin{array}{l}\text { Mashed orange-fleshed sweet } \\
\text { potato }\end{array}$ & Extraction with acetone, THF, and THF:MeOH (1:1) & $\begin{array}{l}\text { PDA Phenomenex LUNA C } 18 \text { ODS, } 250 \times 4.6 \mathrm{~mm} \text {, } \\
5 \mu \mathrm{m}, \mathrm{ACN}: \mathrm{THF}: \mathrm{MeOH}: 1 \mathrm{~g} / 100 \mathrm{~mL} \mathrm{NH} \mathrm{NH}_{4} \mathrm{C}_{3} \mathrm{O}_{2} \\
(68: 22: 7: 3) \text { at room temperature and } 450 \mathrm{~nm}\end{array}$ & [288] \\
\hline Selected vegetables & $\begin{array}{l}\text { Extraction with THF and } \mathrm{MeOH}(1: 1) \text {, petroleum } \\
\text { ether containing } 0.1 \mathrm{~g} / 100 \mathrm{~mL} \mathrm{BHT} \text { and } 50 \mathrm{~mL} \\
10 \mathrm{~g} / 100 \mathrm{~mL} \mathrm{NaCl}\end{array}$ & $\begin{array}{l}\text { HPLC-APCI }{ }^{ \pm}-\mathrm{MS} \text {, Phenomenex Luna } \mathrm{Si}_{18} \\
\text { column }(250 \times 2 \mathrm{~mm}, 5 \mu \mathrm{m}), \mathrm{ACN} \\
0.1 \mathrm{~g} / 100 \mathrm{~mL} / \mathrm{MeOH}\left(0.05 \mathrm{~mol} \mathrm{~L}^{-1} \mathrm{NH}_{4} \mathrm{C}_{2} \mathrm{H}_{3} \mathrm{O}_{2}\right. \\
0.05 \mathrm{~mL} / 100 \mathrm{~mL} \text { TEA }) / \mathrm{CHCl}_{3}(0.1 \mathrm{~g} / 100 \mathrm{~mL} \\
\text { BHT }) / \mathrm{n} \text {-heptane }(0.1 \mathrm{~g} / 100 \mathrm{~mL} \text { BHT }), \text { ambient } \\
\text { temperature }\end{array}$ & [289] \\
\hline $\begin{array}{l}\text { Fresh and Processed Fruits and } \\
\text { Vegetables }\end{array}$ & $\begin{array}{l}\text { Extraction under subdued yellow light. 50:50 } \\
\text { acetone/hexane } \\
\text { Saponification: saturated methanolic } \mathrm{KOH} \\
\text { SPE Alumina N Sep Pak }\end{array}$ & $\begin{array}{l}\text { UV, YMC Carotenoid } 250 \times 4.6 \mathrm{~mm}, 5 \mu \mathrm{m} \text {, mobile } \\
\text { phase } 89: 11 \mathrm{MeOH} / \mathrm{MTBE}\end{array}$ & [290] \\
\hline $\begin{array}{l}\text { Papaya (Carica papaya L., cv. } \\
\text { Maradol) }\end{array}$ & $\begin{array}{l}\text { Freeze-dried papaya homogenized in hexane: } \\
\mathrm{CH}_{2} \mathrm{Cl}_{2}(1: 1) \text {. Organic phase was separated and } \\
\text { saponified with methanolic } \mathrm{KOH} 40 \mathrm{~g} / 100 \mathrm{~mL}(1: 1) \\
\text { for } 1 \mathrm{~h} \text { at } 50{ }^{\circ} \mathrm{C}\end{array}$ & 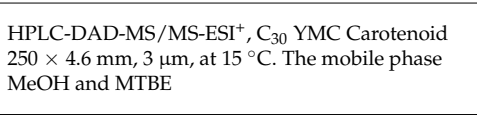 & [291] \\
\hline Papaya (Carica papaya L.) & $\begin{array}{l}\text { MeOH ethyl acetate, and light petroleum (bp } \\
40-60^{\circ} \mathrm{C} \text { ) containing } 0.1 \mathrm{~g} / \mathrm{L} \text { of both } \mathrm{BHT} \text { and } \\
\text { BHA (butylated hydroxyanisole) }\end{array}$ & $\begin{array}{l}\text { DAD, YMC Carotenoid } 250 \times 3.0 \mathrm{~mm}, 3 \mu \mathrm{m} \text { at } \\
25^{\circ} \mathrm{C} \text {. Mobile phase } \mathrm{MeOH} / \mathrm{MTBE} / \mathrm{H}_{2} \mathrm{O}(91: 5: 4) \\
\text { and } \mathrm{MeOH} / \mathrm{MTBE} / \mathrm{H}_{2} \mathrm{O}(6: 90: 4)\end{array}$ & [292] \\
\hline $\begin{array}{l}\text { Yellow and red nance fruits } \\
\text { (Byrsonima crassifolia (L.) Kunth) }\end{array}$ & $\begin{array}{l}\text { Sample with } \mathrm{CaCO}_{3}, \mathrm{NaCl} \text { solution }(30 \mathrm{~g} / 100 \mathrm{~mL} \text {, } \\
\text { were extracted } \\
\text { MeOH/ethyl acetate/light petroleum 1:1:1 } \\
\text { Saponification: methanolic } \mathrm{KOH} 30 \mathrm{~g} / 100 \mathrm{~mL} \\
\text { stirring for } 23 \mathrm{~h}\end{array}$ & $\begin{array}{l}\text { HPLC-PDA-MS/ESI }{ }^{+}, \mathrm{C}_{30} \mathrm{YMC} \text { Carotenoid } \\
250 \times 3.0 \mathrm{~mm}, 3 \mu \mathrm{m}, \mathrm{MeOH} / \mathrm{H}_{2} \mathrm{O} / \text { aqueous } \\
\mathrm{NH}_{4} \mathrm{C}_{2} \mathrm{H}_{3} \mathrm{O}_{2} 1 \mathrm{~mol} \mathrm{~L}{ }^{-1}(90: 8: 2) \text { and } \\
\text { MTBE } / \text { methanol/aqueous } \mathrm{NH}_{4} \mathrm{C}_{2} \mathrm{H}_{3} \mathrm{O}_{2} 1 \mathrm{~mol} \mathrm{~L}^{-1} \\
(78: 20: 2) \text {, gradient, at } 40^{\circ} \mathrm{C} \text {. UV } \lambda 450 \mathrm{~nm}\end{array}$ & [295] \\
\hline $\begin{array}{l}\text { Red and Yellow Physalis (Physalis } \\
\text { alkekengi L. and P. pubescens L.) } \\
\text { Fruits and Calyces }\end{array}$ & $\begin{array}{l}\text { Extraction: } \mathrm{CaCO}_{3}, \mathrm{MeOH} / \text { ethyl } \\
\text { acetate/petroleum ether (1:1:1), containing } \\
0.1 \mathrm{~g} \mathrm{~L}^{-1} \mathrm{BHA} \text { and BHT., sonication }\end{array}$ & $\begin{array}{l}\text { HPLC-PDA-MS } / \mathrm{ESI}^{ \pm}, \mathrm{C}_{30} \text { YMC Carotenoid } \\
(250 \times 4.6 \mathrm{~mm}, 3 \mu \mathrm{m} \text {, mobile phase } \\
\mathrm{MeOH} / \mathrm{MTBE} / \mathrm{H}_{2} \mathrm{O}(80: 18: 2) \text { and } \\
\mathrm{MeOH} / \mathrm{MTBE} / \mathrm{H}_{2} \mathrm{O}(8: 90: 2) \text {, both } 0.4 \mathrm{~g} \mathrm{~L}^{-1} \\
\mathrm{NH}_{4} \mathrm{C}_{2} \mathrm{H}_{3} \mathrm{O}_{2} \text {.Gradient. }\end{array}$ & [297] \\
\hline
\end{tabular}

Solvent modifiers could be added to the mobile phase, for example triethylamine (TEA). Free silanol groups on the surface of silica deprotonate in the presence of the basic molecules, preventing the analyte from interacting with the medium. The TEA generates a positive impact on peak symmetry, reducing the peak tailing effect, reducing the retention time, and improving the recovery. The addition of triethylamine to the mobile phase can also have negative consequences, such as changes in the $\mathrm{pH}$ of the mobile phase; therefore, it is recommended that TEA be used in low concentration (less than $0.05 \mathrm{~mL} / 100 \mathrm{~mL}$ ) [299].

When using chlorinated solvents, the addition of ammonium acetate to the $\mathrm{MeOH}$ provides sufficient buffer capacity to prevent losses due to acid degradation of carotenoids. Some papers use MTBE as part of the mobile phase. The advantage in using this solvent, instead of chlorinated solvents, lies in the MTBE is less volatile (55.2 vs. $39.6{ }^{\circ} \mathrm{C}$, respectively) and less toxigenic. Depending on the solvent system, a good compound separation may require a longer run time and poorer resolution compared with $\mathrm{MeOH} / \mathrm{ACN} / \mathrm{H}_{2} \mathrm{O} / \mathrm{CH}_{2} \mathrm{Cl}_{2}$. Carotenoid content in tropical pigment-bearing fruits [281,295,300-302], and fish [302] have also been described.

\section{Method Application Experience}

The preferred methodology used in our laboratories is based on the work by Gayosso and coworkers with some modifications [282]. We use MTBE/MeOH as the mobile phase with a gradient 
system for $45 \mathrm{~min}$ with $\mathrm{YMC} \mathrm{C}_{30}(150 \times 3.0 \mathrm{~mm}, 3 \mu \mathrm{m})$ at $0.6 \mathrm{~mL} \mathrm{~min}{ }^{-1}$ and $30^{\circ} \mathrm{C}$. These conditions were applied to identify and quantify carotenoids in food matrices such as palm oil, peach palm, sweet potatoes, papaya, and guava. We extracted the carotenoids from these matrices using a saponification procedure, followed by extraction with ethyl ether. This solvent evaporates at $40{ }^{\circ} \mathrm{C}$ and the residue is reconstituted in $\mathrm{CHCl}_{3}$. Undesired coextractants (e.g., waxes, sterol and tocophenol esters) are usually better solubilized with this solvent than MTBE saving from additional filtration steps and within-system precipitation. Optimization of injection volumes and initial composition of the mobile phase can somewhat mitigate the effect that injecting in a different solvent [303]. Analogous to polyphenols, carotenoid extraction methods must contemplate ester hydrolysis or other treatments to ensure the quantitation of overall amounts of carotenoids. For example, it is common to find carotenoid esters in food matrices, and these adducts present several intrinsic difficulties during carotenoid determination [295]. However, mass spectrometry-based LC is a powerful tool able to discriminate both parent compounds and their esters [295]. Recently, Wen and coworkers identified $n=69$ carotenoids esters in Physalis alkekengi L. and P. pubescens L. fruits [297]. Additionally, BHA and BHT are common organic-solvent-soluble antioxidants to preserve carotenoid integrity [298]. Finally, our laboratory has also assessed carotenoid content in plasma from colored tropical frogs (Agalychnis callidryas).

\subsection{Carbohydrates and Sugars Soluble in Ethanol}

Animal feeds are, by definition, based on vegetable/plant sources that use carbohydrates as storage compounds, structure elements, and energy sources [10]. Then, carbohydrates form the most substantial portion of the organic matter in feeds; they can be divided into two main categories non-structural and structural carbohydrates. We encourage the reader to examine an excellent review of carbohydrate and organic acid in food commodities intended for human consumption by da Costa and Conte-Junior [304]. A great starting point for reviewing different approaches for carbohydrate analysis is the thesis written by de Goeij [305].

\subsubsection{Carbohydrate Measurement Using Amino-Based Columns}

$\mathrm{Xu}$ and coworkers compared two methods for sample cleanup and extraction. A macroporous resin was compared to a solid phase sorbent based on alkyl chain. From the two approaches, SPE showed less analyte loss (11.32 vs. $0.69 \%)$. However, the discoloration ratio was similar for both methods. Sugar profile from molasses samples was obtained [305] after pigments, nitrogen compounds, and inorganic ions were removed. The analysis was performed using two $\mathrm{NH}_{2}$-based columns. Under the same conditions, it was concluded that the Zorbax Carbohydrate column showed better performance. Agius and coworkers recently developed a method to determine organic acid and sugars in tomato fruits [306]; the authors used ACN to improve peak shape. RID (Refractive Index Detector) is used for carbohydrate analysis since sugars do not have chromophores and alternative detectors (e.g., MS) are expensive. RID is the detector of choice in many labs for sugar profiling (Table 14) despite its relative lack of sensitivity. However, usual concentrations found in fruits counteract the issue. 
Table 14. Different methods and stationary phases to assess carbohydrates in food matrixes.

\begin{tabular}{|c|c|c|c|c|}
\hline Matrix & Sample Pretreatment, Extraction & $\begin{array}{l}\text { Mobile Phase } \\
\text { Composition }\end{array}$ & $\begin{array}{l}\text { Measurement Method, } \\
\text { Chromatographic Column }\end{array}$ & Reference \\
\hline \multicolumn{5}{|c|}{ Amine-Based Columns } \\
\hline Molasses & $\begin{array}{l}\text { 1. SPE Sep-Pak } C_{18} \\
\text { 2. Microporous resin discoloration } \\
\text { (Seplite } \mathrm{LX}), 30^{\circ} \mathrm{C}\end{array}$ & $\mathrm{ACN}: \mathrm{H}_{2} \mathrm{O}(75: 25)$ & $\begin{array}{l}\text { RID, IS: maltose } \\
\text { 1. Zorbax Carbohydrate } \\
\text { 2. Ultimate } \mathrm{XB}^{\mathrm{TM}} \mathrm{NH}_{2} \text {; both } \\
250 \times 4.6 \mathrm{~mm}, 5 \mu \mathrm{m}\end{array}$ & [307] \\
\hline Tomato & $\begin{array}{l}\text { Filtration, } \mathrm{ACN} / \mathrm{H}_{2} \mathrm{O}(45: 55), \mathrm{SPE} \\
\text { Chromabond } \mathrm{NH}_{2}\end{array}$ & $\mathrm{ACN}: \mathrm{H}_{2} \mathrm{O}(80: 20)$ & $\begin{array}{l}\text { Nucleodur } 100-5 \mathrm{NH}_{2} \\
125 \times 4 \mathrm{~mm} \text {, RID, IS: lactose }\end{array}$ & [306] \\
\hline \multicolumn{5}{|c|}{ Amide-Based Columns } \\
\hline $\begin{array}{l}\text { Confectionery, } \\
\text { chocolate products, } \\
\text { snacks }\end{array}$ & $\begin{array}{l}\text { Defat (when applicable), } \\
\mathrm{H}_{2} \mathrm{O} 80^{\circ} \mathrm{C}(+\mathrm{EtOH} \text { for } \\
\text { chocolate products) }\end{array}$ & $\begin{array}{l}\text { gradient } \\
\mathrm{ACN} / \mathrm{H}_{2} \mathrm{O}+0.05 \\
\mathrm{~mL} / 100 \mathrm{~mL} \\
\text { ethanol- and } \\
\text { triethyl- amine }\end{array}$ & $\begin{array}{l}\text { UPLC-ELSD, Acquity BEH Amide } \\
(50,100,150) \times 2.1 \mathrm{~mm}, 1.7 \mu \mathrm{m}, \\
85^{\circ} \mathrm{C}\end{array}$ & [308] \\
\hline Apple Juice & Filtration & $\mathrm{H}_{2} \mathrm{O}$ & $\begin{array}{l}\text { RID, Sugar Pak }{ }^{\mathrm{TM}} 300 \times 6.5 \mathrm{~mm} \text {, } \\
10 \mu \mathrm{m}, 80^{\circ} \mathrm{C}\end{array}$ & [309] \\
\hline \multicolumn{5}{|c|}{ Ligand-Based Columns } \\
\hline Tubers & $\begin{array}{l}\text { 1. } \mathrm{H}_{2} \mathrm{O} 92{ }^{\circ} \mathrm{C} \\
\text { 2. Reflux } \mathrm{MeOH} / \mathrm{H}_{2} \mathrm{O}(50: 50) \\
\text { 3. Activated } \mathrm{Charcoal} / \mathrm{MeOH} \\
\text { 4. } 2 \times \cdot \mathrm{MeOH} / \mathrm{H}_{2} 0 \text { 50:50 SPE } \\
\text { Bond-Elut } \mathrm{C}_{18}\end{array}$ & $\begin{array}{l}10 \mathrm{mmol} \mathrm{L}^{-1} \\
\mathrm{H}_{2} \mathrm{SO}_{4}\end{array}$ & $\begin{array}{l}\text { RID, UHPLC Aminex HPX } 87 \mathrm{H} \\
300 \times 7.8 \mathrm{~mm}, 9 \mu \mathrm{m}, 18^{\circ} \mathrm{C}\end{array}$ & [310] \\
\hline Foods & $\begin{array}{l}\text { Liquids: } \mathrm{H}_{2} \mathrm{O} / \mathrm{EtOH}(50: 50) \\
\text { Solids: } \mathrm{H}_{2} \mathrm{O} 65^{\circ} \mathrm{C} \text {, sonication, } \\
+ \text { EtOH Fat-/ Protein-rich: } \\
\mathrm{H}_{2} \mathrm{O} / \mathrm{EtOH}(20: 80) \text {, sonication }\end{array}$ & $\begin{array}{l}\text { 1. } \mathrm{H}_{2} \mathrm{O} \\
\text { 2. } \mathrm{ACN}: \mathrm{H}_{2} \mathrm{O}(9: 1)\end{array}$ & $\begin{array}{l}\text { 1. HPLC-RID Ultron PS- } 80 \mathrm{P} \\
300 \times 6.5 \mathrm{~mm}, 10 \mu \mathrm{m}, 50^{\circ} \mathrm{C} \\
\text { 2. LC-MS-ESI }{ }^{ \pm} \text {Unison } \\
\text { UK-Amino } 150 \times 2.0 \mathrm{~mm}, 3 \mu \mathrm{m}\end{array}$ & [311] \\
\hline \multicolumn{5}{|c|}{ Derivatization-Based Approaches } \\
\hline Fruit tree buds & $\begin{array}{l}\text { MeOH extraction, benzyl } \\
\text { alcohol/NaOH } 8 \mathrm{~mol} \mathrm{~L}^{-1} \text {, SPE } \\
\mathrm{C}_{18}\end{array}$ & $\begin{array}{l}\text { Gradient } \\
\mathrm{ACN} / \mathrm{H}_{2} \mathrm{O}\end{array}$ & $\begin{array}{l}\text { PDA } \lambda 228 \text { and } 248 \mathrm{~nm} \text {, Shim-pack } \\
\mathrm{C}_{18} 250 \times 4.6 \mathrm{~mm}, 5 \mu \mathrm{m}\end{array}$ & [312] \\
\hline Foods & $\begin{array}{l}\text { 2,3-naphtalenediamine, iodine, } \\
\text { HAOc }\end{array}$ & $\begin{array}{l}\mathrm{NH}_{4} \mathrm{O}_{2} \mathrm{CH}_{3} 50 \\
\text { mmol L-1 pH } 5.0 \\
\text { in } \mathrm{ACN} / \mathrm{MeOH} \\
(70: 30)\end{array}$ & $\begin{array}{l}\text { RID (sucrose / fructose) } / \text { UV } \lambda 310 \\
\text { FLD } \lambda_{\mathrm{ex}} 320 \lambda_{\mathrm{em}} 360 \mathrm{~nm}, \mathrm{C}_{18} \\
250 \times 4.6 \mathrm{~mm}\end{array}$ & [313] \\
\hline & & Normal Phase & & \\
\hline $\begin{array}{l}\text { Glycine max (L.) } \\
\text { Merr }\end{array}$ & $\mathrm{H}_{2} \mathrm{O} 55^{\circ} \mathrm{C}, \mathrm{ACN}$ & $\begin{array}{l}\mathrm{H}_{2} \mathrm{O} / \mathrm{ACN}+ \\
\text { Acetone }(75: 25)\end{array}$ & $\begin{array}{l}\text { ELSD }^{\text {Prevail }}{ }^{\mathrm{TM}} \text { Carbohydrate ES } \\
250 \times 4.6 \mathrm{~mm}, 5 \mu \mathrm{m}\end{array}$ & [314] \\
\hline \multicolumn{5}{|c|}{ Complex Carbohydrates (e.g., Inulin and Fructans) } \\
\hline $\begin{array}{l}\text { Plants and feed } \\
\text { materials }\end{array}$ & $\mathrm{H}_{2} \mathrm{O}$ & $\begin{array}{l}\mathrm{H}_{2} \mathrm{O} \text { or } \mathrm{H}_{2} \mathrm{SO}_{4} 0.01 \\
\mathrm{~mol} \mathrm{~L}^{-1}\end{array}$ & $\begin{array}{l}\text { 1. Knauer Eurokat Pb } \\
\text { 2. Nucleosil CHO } 620 \\
\text { 3. Nucleosil CHO } 682(\mathrm{~Pb}) \\
\text { 4. Biorad Aminex HPX-87C. All } \\
\text { columns } 300 \times 7.8 \mathrm{~mm} \text {, RID }\end{array}$ & [315] \\
\hline Wheat & $\begin{array}{l}\mathrm{HCl} 60 \mathrm{mmol} \mathrm{L}^{-1} 70{ }^{\circ} \mathrm{C} \text {, } \\
\text { quenching } \mathrm{Na}_{2} \mathrm{CO}_{3}\end{array}$ & $\begin{array}{l}90 \mathrm{mmol} \mathrm{L}^{-1} \\
\mathrm{NaOH}\end{array}$ & $\begin{array}{l}\text { Carbopac-PA-100 } \\
250 \times 4.0 \mathrm{~mm}, \text { PAD }\end{array}$ & [316] \\
\hline $\begin{array}{l}\text { Fungus sucrose } \\
\text { fermentation }\end{array}$ & Filtration & $\begin{array}{l}\mathrm{ACN} / 0.04 \mathrm{~g} / 100 \\
\mathrm{~mL} \mathrm{NH}{ }_{4} \mathrm{OH}(70: 30)\end{array}$ & $\begin{array}{l}\text { RID, Knauer Eurospher 100-5 } \\
\mathrm{NH}_{2} \text { Vertex } 25 \times 4.6 \mathrm{~mm}\end{array}$ & [317] \\
\hline Starch from feeds & $\begin{array}{l}\text { heat stable amylase and } \\
\text { amyloglucosidase }\end{array}$ & $\mathrm{ACN} / \mathrm{H}_{2} \mathrm{O}(80: 20)$ & $\begin{array}{l}\text { RID, Zorbax Carbohydrate } \\
150 \times 4.6 \mathrm{~mm}, 5 \mu \mathrm{m}\end{array}$ & [318] \\
\hline Wine & $\begin{array}{l}\text { Diluted 1:9 with EtOH } 70 \mathrm{~mL} / 100 \\
\mathrm{~mL} \text { and } \\
\text { 1-phenyl-3-methyl-5-pyrazolone } \\
\text { derivatization }\end{array}$ & $\begin{array}{l}\mathrm{ACN} / 0.1 \mathrm{~mol} \mathrm{~L}^{-1} \\
\mathrm{~g} / 100 \mathrm{~mL} \\
\mathrm{NH}_{4} \mathrm{C}_{2} \mathrm{H}_{3} \mathrm{O}_{2} \\
(70: 30)\end{array}$ & $\begin{array}{l}\mathrm{UV} \lambda 245 \mathrm{~nm} \text {, Eclipse } \mathrm{XDB}^{-\mathrm{C}_{18}} \\
250 \times 4.6 \mathrm{~mm}, 5 \mu \mathrm{m}\end{array}$ & [319] \\
\hline $\begin{array}{l}\text { Bacterial } \\
\text { Exopolysaccharide }\end{array}$ & $\begin{array}{l}\text { Microplate polysaccharide } \\
\text { hydrolysis } 4 \text { mol } \mathrm{L}^{-1} \mathrm{CF}_{3} \mathrm{COOH} \text {, } \\
90 \text { min at } 121^{\circ} \mathrm{C} \text {. Derivatization } \\
\text { 1-phenyl-3-methyl-5-pyrazolone }\end{array}$ & $\begin{array}{l}5 \mathrm{mmol} \mathrm{L}^{-1} \\
\mathrm{NH}_{4} \mathrm{C}_{2} \mathrm{H}_{3} \mathrm{O}_{2} \mathrm{pH} \\
\text { 5.6/ACN gradient }\end{array}$ & $\begin{array}{l}\text { Gravity } \mathrm{C}_{18}, 100 \times 2 \mathrm{~mm}, 1.8 \mu \mathrm{m} \text {, } \\
\text { HPLC-UV-Ion trap/ESI }{ }^{+}-\mathrm{MS}\end{array}$ & [320] \\
\hline
\end{tabular}

\subsubsection{Carbohydrate Measurement Using Amide-Based Columns}

Koh and coworkers developed a method using an amide-based column, which is designed to retain polar molecules [308]. Contrary to their amino counterparts, these columns can retain 
analytes wide range of mobile phase $\mathrm{pH}$. Thirteen sugars were separated including monosaccharides, disaccharides, sugar alcohols. This separation is impressive since it includes several molecules commonly used as sugar substitutes or replacement sweeteners. Organic amines within the mobile phase are used as stationary phase modifiers [308]. The authors recommended the use of a $150 \mathrm{~mm}$ column as the reduction of time of analysis using shorter lengths, compromise resolution. However, peaks obtained on longer columns are typically wider peaks resulting in lower sensitivity due to increased diffusion.

\subsubsection{Carbohydrate Measurement Using Ligand Exchange-Based Columns}

Duarte-Delgado and coworkers assayed four different extraction methods for sucrose, glucose, and fructose, and demonstrated that a double aqueous $\mathrm{MeOH}$ extraction was the more efficient approach for the determination of these sugars [310]. The authors used SPE and guaranteed the removal less polar compounds and avoid possible co-elution with sugars during HPLC analysis. Extraction method seems to be more critical for mono than disaccharides, and starch gelification appears to be an interference when extraction is performed with hot water. Zielinski and coworkers a cation exchange gel in calcium form column to determine sucrose, D-glucose, fructose, and sorbitol in different ripe stages and during senescence of Malus domestica (Suckow) Borkh [309].

Senescent apple juice showed higher sugar concentration; a stage in which fruit is better suited for fermentation. Shindo and coworkers used recovered sugars from samples such as orange juice, yogurt, chewing gum, milk, and biscuits (this last matrix needed a triple extraction to obtain adequate recoveries). Additionally, the authors optimized column temperature and flow rate [311].

\subsubsection{Reverse Phase Columns and Sugar Derivatization Techniques}

Several detection systems are used to detect carbohydrate after chromatographic separation, an approach commonly used is the pulsed electrochemical detection. A thorough review of this technique has been already written by Corradini and coworkers [321]. Evaporative light scattering detector has also been used to assay sugars. Dvořáčkova and coworkers wrote a comprehensive review of this technique [322]. The most common detector for chromatographic analysis of sugars is refractive index. UV detection is usually inconvenient as the wavelength $210 \mathrm{~nm}$ (low range of the UV) has the disadvantage of exhibiting interferences. An easy way to circumvent this to derivatize using pyrazolones (e.g., 1-phenyl-3-methyl-5-pyrazolone) to form Schiff bases with reducing sugars and monitor using $248 \mathrm{~nm}$. This approach only works for reducing sugars. Hence, sucrose will not be detectable. Additionally, a $\mathrm{C}_{18}$ column (usually readily available) can be used to separate the adducts. Canesin and coworkers analyzed sorbitol from lateral buds of fruit trees (e.g., black mulberry, peach, avocado, and pear) as a way to monitor primary photosynthesis products [312]. In this case, traditional detection systems are not useful as levels of sorbitol are in the $\mu \mathrm{g}$ per $\mathrm{mg}$.

Hung and coworkers were able to add a fluorophore to aldol sugars assisting in their detection and mass fragmentation [313]. Naphthylimidazole fluorescent derivatives were obtained successfully for sugars (only for reducing aldoses) extracted from beverages such as fruit juice, yogurt, coffee drink, milk tea, and flavored milk. Additionally, oligosaccharides from a Solanaceae were identified using the approach above and NMR as an additional confirmatory tool. Recently, special attention has been drawn toward added sugars in food commodities; sterner regulations have been set in different countries due to population health concerns such as obesity, diabetes, and heart disease [323]. Hung and coworkers also used their approach to assess added sugar in the food items tested [313]. Carbohydrates analysis in food should contemplate, systematically, added sugars during chemical determinations [324].

\subsubsection{Aqueous Normal Phase Chromatography for Sugars}

Interestingly, Valliyodan and coworkers used an aqueous normal phase approach based on a hydrophilic polymeric gel) to assess sugars from soybean. The addition of just $20-30 \mathrm{~mL} / 100 \mathrm{~mL}$ 
of acetone to acetonitrile, in the mobile phase, permitted the successful separation of galactose from glucose [314].

\subsubsection{Complex Carbohydrates and Conjugates}

Hydrolysis of complex (mainly structural) carbohydrates has been used previously to assess them $[325,326]$ by indirect determination of their basic units and building blocks. Several approaches can be used to achieve this [325]. However, HPLC can be an attractive one since it provides high specificity and selectivity. As hydrolysis usually produces considerable concentrations of the monomer, usually sensitivity is not an issue. For example, we have used endo-1,4- $\beta$-mannanase (EC 3.2.1.78) to break down and indirectly determine mannan, monitoring mannose. Similarly, hydrolysis can be used to assess the quality of commercial mannanase. Mannanase is commonly used as a feed ingredient to improve nutrient absorption [10]. Here, an enzyme of known activity (a standard, see for example E-BMANN from Megazyme) is directly compared to the commercial one (the feed additive); a galactomannan polysaccharide (like guar gum) can be used as the substrate.

Weiß and Alt described an exhaustive method to assay sugars in plant materials and feeds. Separation of the following was achieved: inulin, verbascose, stachyose, raffinose, cellobiose, sucrose, isomaltose, maltose, lactose, glucose, xylose, galactose, rhamnose, arabinose, fructose, mannose, ribose, and mannitol [315]. Flow rate, temperature, mobile phase composition, and injection volume were optimized. From the series of columns tested, the Nucleosil ${ }^{\circledR}$ Sugar $682 \mathrm{~Pb}$ (Macherey-Nagel GmbH \& Co. KG, Düren, Germany) was finally used at $85{ }^{\circ} \mathrm{C}, \mathrm{H}_{2} \mathrm{O}$ at $0.4 \mathrm{~mL}$ $\min ^{-1}$, and using $20 \mu \mathrm{L}$. Recent data show that inulin-rich diets can benefit gut microbiome, notwithstanding, routine inulin analysis in feeds is uncommon [327]. It was not until very recently that the minimal performance requirements were established for fructans analysis in feed, pet food, and their ingredients [328]. However, excess dietary fructans have demonstrated adverse health effects in equines [329]. AOAC ${ }^{\circledR}$ (Rockville, Maryland, USA) Official Method ${ }^{\mathrm{SM}} 997.08$ is available to assess fructans in food products using ion exchange chromatography with pulsed amperometric detection. The method is based on two-step hydrolysis using amyloglucosidase (to remove starch) and inulinase. Measurement of simple sugars in different food-derived extract fractions is performed using glucoheptose as an internal standard. The same principle has been used to assess fructose derived from fructans in pet food [330]. Verspreet and coworkers analyzed fructan from wheat grains after acid hydrolysis. Mild conditions used during hydrolysis avoid the release from other naturally occurring saccharides in wheat that would otherwise interfere during the fructan estimation (e.g., raffinose oligosaccharides) [316]. Correia and coworkers have developed a method to analyze fructooligosaccharides [317]. These sugars are dietary and are used as food ingredients (incorporated as dietary fibers in commodities). The authors monitored sucrose pathway fermentation products from Aspergillus aculeatus as a potential source of fructooligosaccharides; fructose, glucose, sucrose, 1-kestose, nystose, and $1^{\mathrm{F}}$-Fructofuranosylnystose were monitored.

We have used enzymatic hydrolysis to obtain glucose from starch molecules present in feed and feed ingredients. Total and resistant starch was measured in several matrices including (e.g., silages) [318]. Bai and coworkers analyzed mono- and oligosaccharides from Hakka rice [319] as a measure of quality for sugars such as isomaltotriose, isomaltose, panose, maltose, and glucose. Finally, the determination of bacterial exopolysaccharides has also been reported [320,331].

\subsubsection{Method Application Experience}

Amine-based columns (e.g., Zorbax ${ }^{\circledR}$ Carbohydrate (Agilent technologies, Santa Clara, USA), Ultisil $^{\circledR}$ XB-NH (Welch Materials, Inc, Texas, USA)) are successful in separating mono and disaccharides in foods especially those containing lactose (such as dairy products). However, this type of stationary phase suffers easily from poisoning as amine functional groups form covalent bonding with several compounds (e.g., Schiff bases). As the amine functional group is sensitive to $\mathrm{pH}$ changes, extracts must be adjusted to avoid changes in the chemical form of the stationary phase functional 
group as this may affect repeatability/reproducibility or even obliterate the column capacity for retention. Hence, the elimination of interferences is paramount. Additionally, when retention capacity is lost, it is possible to apply changes in the mobile phase composition and flow (e.g., to increase acetonitrile concentration and reduce flow).

A particular case is that of coffee samples. Amine-based columns especially suffer when analyzing coffee extracts as they contain phenolic acids (e.g., chlorogenic, syringic, ferulic, protocatechuic and hydroxybenzoic acid) and alkaloids (e.g., caffeine, caffeic acid, theophylline, trigonelline) [332]. Costa Rican regulations accept not more than $10 \mathrm{~g} / 100 \mathrm{~g}$ sucrose in roasted coffee. Hence, monitoring sugar levels, as a quality standard, in these products is paramount. When routine quality control in coffee samples is necessary, we recommend to use stationary phases more resistant to $\mathrm{pH}$ changes (e.g., amide-based), include mobile phase modifiers (e.g., triethylamine), or intensive extract clean up.

In the case of animal compound feed, for example, suckling pigs feed usually contain lactose. Contrary to the amine-based column (Figure 8A,B and Figure 9A), ion exclusion (e.g., Agilent Hi-Plex Ca, Phenomenex ${ }^{\circledR}$ Rezex ${ }^{\mathrm{TM}}$ RCU-USP Ca ${ }^{2+}$ (Torrance, California, USA)) is better equipped to deal with a larger range of samples and is less prone to deteriorate.

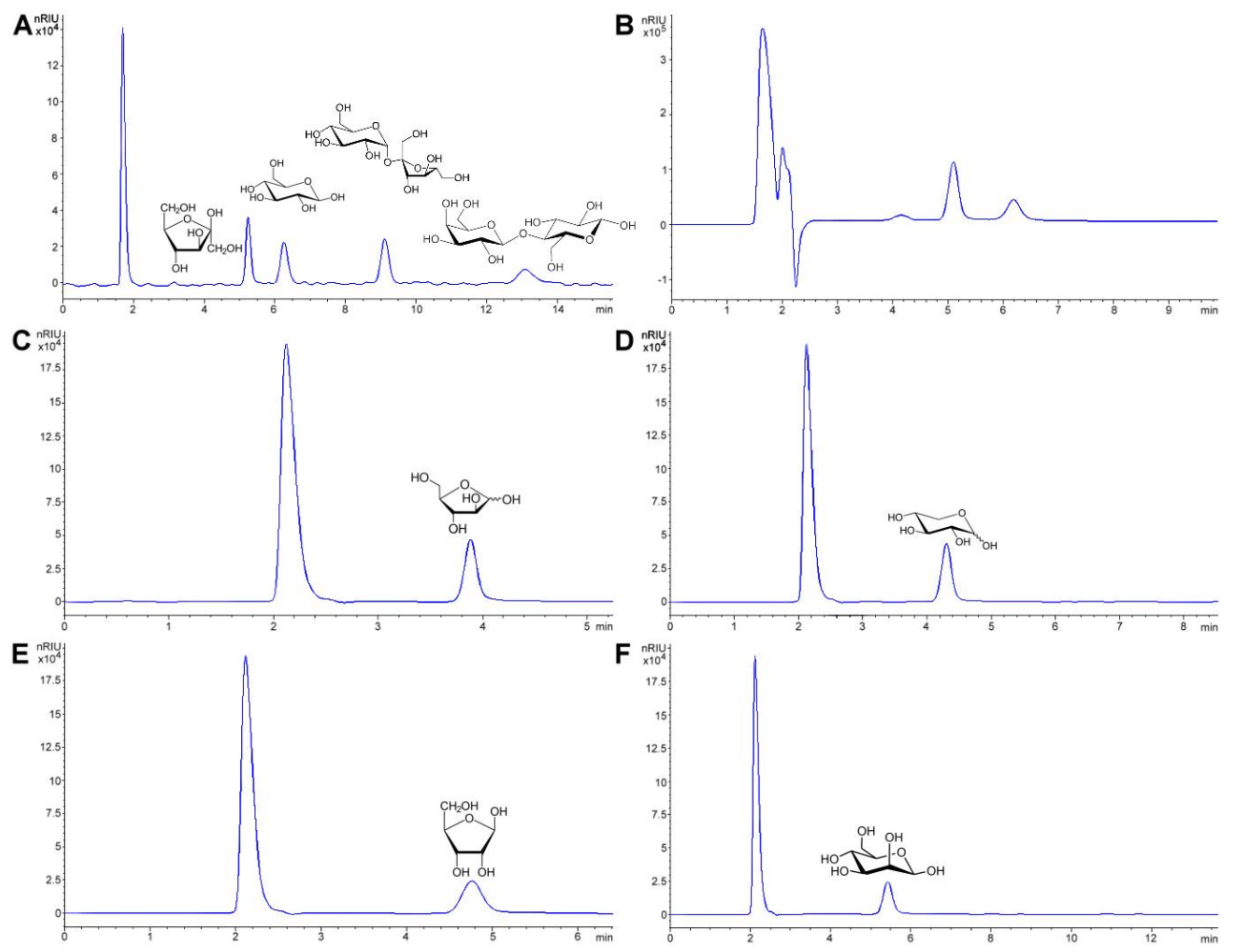

Figure 8. Chromatographs of (A) $2 \mathrm{~g} / 100 \mathrm{~mL}$ standard mixture of four sugars including fructose (5.24 $\mathrm{min})$, glucose $(6.26 \mathrm{~min})$, sucrose $(9.12 \mathrm{~min})$, and lactose (13.09 $\mathrm{min}$ ) separated using amino column (Zorbax Carbohydrate, $0.7 \mathrm{~mL} \mathrm{~min}^{-1}$, $80 \mathrm{ACN}$ : $20 \mathrm{H}_{2} \mathrm{O}$ ). (B) Sugar content of a molasses sample after hot water extraction, fructose $(5.18 \mathrm{~min})$ and glucose $(6.31 \mathrm{~min})$ signals are evident. (C) $1 \mathrm{~g} / 100 \mathrm{~mL}$ standard solution for arabinose (3.89 $\mathrm{min})$ (D) $1 \mathrm{~g} / 100 \mathrm{~mL}$ standard solution for xylose (4.30 $\mathrm{min}$ ) (E) $1 \mathrm{~g} / 100 \mathrm{~mL}$ standard solution for ribose (4.76 $\mathrm{min})$, and (F) $1 \mathrm{~g} / 100 \mathrm{~mL}$ standard solution for mannose (5.42 $\mathrm{min}$ ). Signal at ca. $1.80 \mathrm{~min}$ corresponds to the solvent front; constant in all injections. 
A

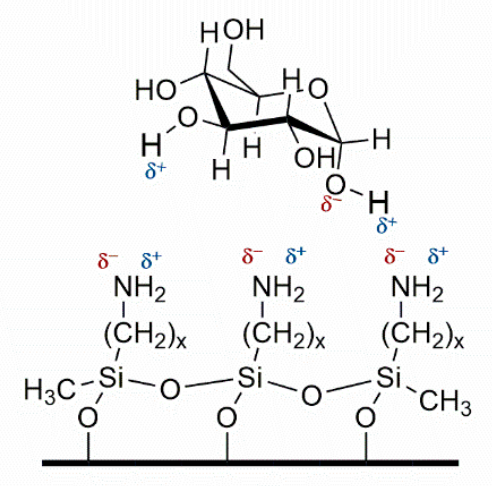

B

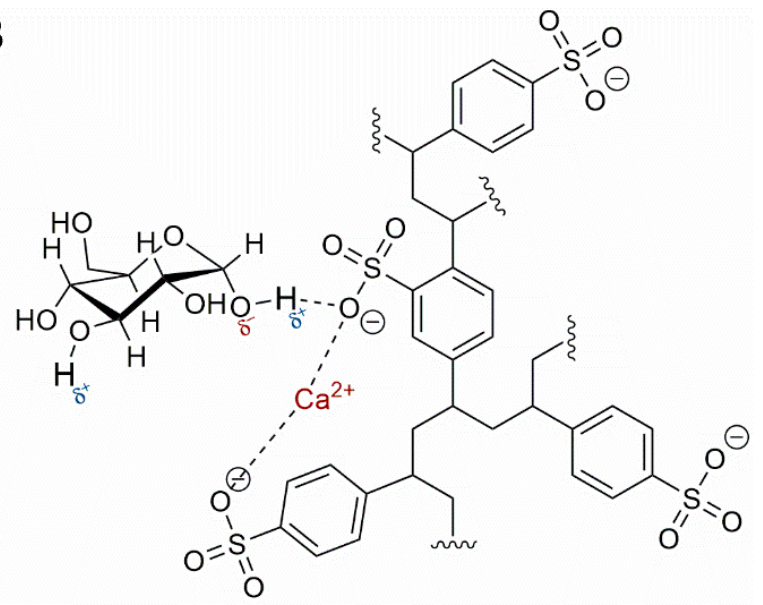

Figure 9. Schematic representation of sugar interaction mechanism using (A) amine based (B) calcium ion-based ligand exchange column.

These types of columns are able to separate $\mathrm{H}^{+}$(organic acids/monosaccharides), $\mathrm{Na}^{+}$, $\mathrm{Ca}^{2+}$ (sugars/alcohols), $\mathrm{Ag}^{+}$and $\mathrm{Pb}^{2+}$ (oligosaccharides). Sugars and alcohols are separated using ligand exchange (Figure 9B) and organic acids by ion exchange. During ligand exchange, the more complex sugars elute first whereas simple ones, such as fructose, elute last, opposite to the elution order found in amine-based columns. Another advantage is that ion exchange columns need ultra-high purity water (type I) to segregate analytes while amino-based columns require acetonitrile in the mobile phase to perform. However, amino-based columns have the inherent advantage that complete chromatographic runs can be achieved under $12 \mathrm{~min}$ (while setting the column at $30^{\circ} \mathrm{C}$ ). Meanwhile, a good separation using exchange columns can be extended up to $30 \mathrm{~min}$ at $60^{\circ} \mathrm{C}$. As LC-MS usually use low flow rates to aid in solvent nebulization, it is harder to develop methods using this type of column due to their dimensions. When using ion exchange based-columns, EDTA can be used to sequestrate ions present on complex sample extracts reducing interferences. Peak tailing or fronting is also common when there is already wear of the chromatographic column. Finally, mathematic designs can be used to optimize method critical parameters and attributes, at least one research group has used this approach (i.e., Monte-Carlo simulation) to analyze sugars in herbs [333].

\subsection{Organic Acids}

Organic acids are common substances found naturally in several foods and result from fermentation processes [334]. As such, they are responsible for the particular flavor and aroma of commercially relevant commodities such as wine, vinegar, fermented meats, and yogurt, to name just a few. These substances have found widespread use in the food and feed industry as preservatives (increasing shelf-life, [335]) and antimicrobials (due to their bacteriostatic properties) (large-scale use of benzoic acid in beverages is a clear example, [335]). Organic acids can be determined by HPLC using ion exchange columns. Several anion exchange columns have already been mentioned in the previous section. Usually, though, measurement is commonly made using a UV detector at $210 \mathrm{~nm}$ (detection of absorption of carboxyl groups). Solvents and columns may vary slightly, but an isocratic method is sufficient to separate the analytes. The sample preparation for organic acid determination in beverages can be straightforward. In some cases, depending on the clarification, process suffered by the final product, it may consist of centrifugation and microfiltration. For an excellent primer for organic acids, we recommend the book edited by Vargas [336].

\subsubsection{Reverse Phase Chromatography Analysis in Foods}

Neffe-Skocińska and coworkers analyzed sugars, ethyl alcohol and organic acids in Kombucha tea beverages (a fermented brew) with an emphasis on glucuronic acid (which has been associated with 
health benefits) [337]. The fermentative profile was evaluated for 10 days at 3 different temperatures. Nour and coworkers use low temperature so they can separate 6 compounds (oxalic, tartaric, malic, lactic, citric, and ascorbic) in $13 \mathrm{~min}$. The applied temperatures (i.e., $10^{\circ} \mathrm{C}$ ) in a $250 \mathrm{~mm}$ column using $0.7 \mathrm{~mL} \mathrm{~min}^{-1}$ flow rates ensures optimal resolution of the compounds while obtaining adequate peak shapes within a reasonable time. A buffer adjusted at $2.8 \mathrm{pH}$ guarantees that the compounds of interest are maintained during chromatography as protonated species [338].

Different citrus juices were tested finding concentrations of citric acid ranging from $7.39 \times 10^{4}$ to $6.89 \times 10^{4} \mathrm{mg} \mathrm{L}^{-1}$. Reverse phase separation of acids uses buffers (e.g., the $\mathrm{H}_{2} \mathrm{PO}_{4}{ }^{-} / \mathrm{HPO}_{4}{ }^{2-}$ pair) or salts (e.g., $\mathrm{Na}_{2} \mathrm{SO}_{4}$ ) to accomplish separation. The advantage of this approach is that usually $\mathrm{C}_{8} / \mathrm{C}_{18}$ columns are readily available and are relatively inexpensive. The downside resides in that the use of this kind of mobile phases increase the possibility of crystal precipitation in the pump and capillaries. The buffer has to be prepared daily (to circumvent microbial growth), and $\mathrm{pH}$ values strictly supervised (to avoid retention time shifts). Lobo Roriz and coworkers determined organic acids in three different medicinal plants which are widely consumed as infusions. Gomphrena globosa L. showed the highest levels or organic acids (mainly malic and oxalic) [339].

Pterospartum tridentatum (L.) Willk. and Cymbopogon citratus (DC.) Stapf showed higher levels of citric and succinic acids, respectively. Acid content depends on inherent plant genetic characteristics and edaphoclimatic conditions. The authors also analyzed sugars (using HPLC-RID Eurospher $100-5 \mathrm{NH}_{2}$ column and melezitose as internal standard) and, interestingly, tocopherols $(\alpha, \gamma$, and $\delta$-tocopherol, normal phase YMC Polyamide II column and fluorescence at $\lambda_{\mathrm{ex}}$ and $\lambda_{\mathrm{em}} 290 \mathrm{~nm}$ and $330 \mathrm{~nm}$ ). Scherer and coworkers used a reverse phase column to assess ascorbic acid stability in apple, orange and lemon juices. They also compared nutritional analysis reported within the food labels for ascorbic acid with that obtained experimentally [340].

\subsubsection{Ion Exchange Chromatography Analysis in Foods}

Llano and coworkers analyzed sugars, acids, and furfural in pulp mill residue. The authors used a resin-based cross-linked gel column for low molecular-weight chain acids, alcohols, and furfurals. This method is particularly interesting since a comparison between 2 sets of columns for each application was tested (Table 15). The authors also included specific details for each column and optimize temperature, injection volume, and flow rate. Size exclusion also seem to have a role in sugar separation using ion exchange columns [341]. Though this application is not specifically for food, xylooligosaccharides (from revalorization alternatives for materials derived from the pulp mill enterprise) have found applications in the food industry and have been even linked to health benefits [342]. Saleh Zaky and coworkers reported a simultaneous analysis of chlorides, sugars, and acids [343]. However, the paper states that several inorganic ions are retained with the same strength within the column (all tested ions have different physicochemical properties; i.e., hydration spheres, charge among others). We have not been able to repeat this procedure. The authors did analyze sugars and acids (i.e., citric, lactic, acetic) and ethanol in a grand variety of food products including energy drinks, sodas, tomato juice and sauce, brine, milk, whey, cheese, and hummus. An interesting paper focused on the determination of organic acids from olive fruits. Different organic acid profiles were found for unique fruit varieties. They found oxalic, malic, succinic, and citric as main organic acids [344]. 
Table 15. Determination of organic acids and in foods and silage.

\begin{tabular}{|c|c|c|c|c|}
\hline Matrix & $\begin{array}{l}\text { Sample Pretreatment, } \\
\text { Extraction }\end{array}$ & Mobile Phase Composition & Measurement Method, Chromatographic Column & Reference \\
\hline \multicolumn{5}{|c|}{ Reverse Phase-Based Columns } \\
\hline Kombucha & $\mathrm{H}_{2} \mathrm{O} 70-80^{\circ} \mathrm{C}$, filtration & $\begin{array}{l}20 \mathrm{mmol} \mathrm{H}_{2} \mathrm{PO}_{4}^{-} \mathrm{pH} 2.4 / \mathrm{MeOH} \\
(97: 3)\end{array}$ & Luna $\mathrm{C}_{18} 250 \times 4.6 \mathrm{~mm}, 5 \mu \mathrm{m} 30^{\circ} \mathrm{C} \mathrm{UV} \lambda 210 \mathrm{~nm}$ & [337] \\
\hline Fresh fruits & $\begin{array}{l}\text { Juice extraction, depulping, } \\
\text { centrifugation }\end{array}$ & $50 \mathrm{mmol} \mathrm{L}^{-1} \mathrm{H}_{2} \mathrm{PO}_{4}^{-} \mathrm{pH} 2.8$ & $\begin{array}{l}\text { Hypersil Gold aQ } 250 \times 4.6 \mathrm{~mm}, 5 \mu \mathrm{m} 10^{\circ} \mathrm{C} \text { UV } \lambda 214 \mathrm{~nm} \\
\text { (254 ascorbic acid) }\end{array}$ & [338] \\
\hline $\begin{array}{l}\text { Medicinal plants } \\
\text { infusions }\end{array}$ & $\left(\mathrm{HPO}_{3}\right)_{\mathrm{n}}$ extraction & $3.6 \mathrm{mmol} \mathrm{L}^{-1} \mathrm{H}_{2} \mathrm{SO}_{4}$ & $\begin{array}{l}\text { Sphere-Clone } \mathrm{C}_{18} 250 \times 4.6 \mathrm{~mm}, 5 \mu \mathrm{m}, 35^{\circ} \mathrm{C} \mathrm{UV} \lambda 215 \mathrm{~nm} \\
\text { (254 ascorbic acid) }\end{array}$ & [339] \\
\hline Fruit juices & Filtration & $0.01 \mathrm{~mol} \mathrm{~L}^{-1} \mathrm{KH}_{2} \mathrm{PO}_{4} \mathrm{pH} 2.6$ & $\mathrm{RP}^{\mathrm{C}} \mathrm{C}_{18} 150 \times 4.6 \mathrm{~mm}, 3 \mu \mathrm{m}, \mathrm{UV} \lambda 210 \mathrm{~nm}$ & [340] \\
\hline Wine & $\begin{array}{l}\text { SPE C }_{18} \\
\text { Elution: mobile phase (for } \\
\text { acid protonation) }\end{array}$ & $\begin{array}{l}0.005 \mathrm{~mol} \mathrm{~L}^{-1} \mathrm{H}_{3} \mathrm{PO}_{4} \mathrm{pH} 2.1 \\
1 \mathrm{~mL} / 100 \mathrm{~mL} \mathrm{CAN}\end{array}$ & Lichrosorb RP-C $18150 \times 4.0 \mathrm{~mm}, 5 \mu \mathrm{m}, \mathrm{UV} \lambda 210 \mathrm{~nm}$ & [345] \\
\hline \multicolumn{5}{|c|}{ Ion Exchange-Based Columns } \\
\hline Sulfite pulp mill & Filtration & $\begin{array}{l}\text { 1. Ultrapure water } 79^{\circ} \mathrm{C} \\
\text { 2. Ultrapure water } 68^{\circ} \mathrm{C} \\
\text { 3. } \mathrm{H}_{2} \mathrm{SO}_{4} 0.005 \mathrm{~mol} \mathrm{~L}^{-1} 30^{\circ} \mathrm{C} \\
\text { 4. } \mathrm{H}_{2} \mathrm{SO}_{4} 0.005 \mathrm{~mol} \mathrm{~L}^{-1} 60^{\circ} \mathrm{C}\end{array}$ & $\begin{array}{l}\text { RID for all cases, } \\
\text { 1. Aminex HPX-87P Pb } \mathrm{Pb}^{2+} 300 \times 7.8 \mathrm{~mm}, 9 \mu \mathrm{m} \\
\text { 2. Transgenomic }{ }^{\circledast} \mathrm{CHO}^{-} 782 \mathrm{~Pb}^{2+} 300 \times 7.8 \mathrm{~mm}, 7 \mu \mathrm{m} \\
\text { 3. Bio-rad Aminex HPX-87H } 300 \times 7.8 \mathrm{~mm}, 9 \mu \mathrm{m} \\
\text { 4. Shodex SH-1011 } \mathrm{H}^{+} 300 \times 8.0 \mathrm{~mm}, 6 \mu \mathrm{m}\end{array}$ & [341] \\
\hline Food samples & $\begin{array}{l}\text { Liquid samples: filtration } \\
\text { Solid samples: } \mathrm{H}_{2} \mathrm{O} 85^{\circ} \mathrm{C}\end{array}$ & $0.005 \mathrm{~mol} \mathrm{~L}^{-1} \mathrm{H}_{2} \mathrm{SO}_{4} 35^{\circ} \mathrm{C}$ & Hi-Plex H $300 \times 8.0$ mm, $6 \mu \mathrm{m}$, RID & [343] \\
\hline Olive fruits & $\begin{array}{l}\text { Maceration in } \mathrm{H}_{2} \mathrm{O} \text { MeOH } \\
(75: 25)\end{array}$ & $0.1 \mathrm{~g} / 100 \mathrm{~mL} \mathrm{H}_{3} \mathrm{PO}_{4}$ & Shodex RSpak KC-118 $300 \times 8.0 \mathrm{~mm}, \mathrm{UV} \lambda 214 \mathrm{~nm}$ & [344] \\
\hline Wines & $\begin{array}{l}\text { Filtration, SPE strong anion } \\
\text { exchange }\end{array}$ & $0.065 \mathrm{~mL} / 100 \mathrm{~mL} \mathrm{H}_{3} \mathrm{PO}_{4}$ & Aminex HPX-87H $300 \times 7.8 \mathrm{~mm}, 9 \mu \mathrm{m}, 65^{\circ} \mathrm{C}, \mathrm{UV} \lambda 210 \mathrm{~nm}$ & [346] \\
\hline Fermented shrimp waste & $\begin{array}{l}\text { Centrifugation, sonication, } \\
\text { filtration }\end{array}$ & $\left(\mathrm{HPO}_{3}\right)_{\mathrm{n}} \mathrm{pH} 2.1$ & SS Exil ODS $250 \times 4.0 \mathrm{~mm}, 5 \mu \mathrm{m}, \mathrm{UV} \lambda 210 \mathrm{~nm}$ & [347] \\
\hline Silage & $\mathrm{H}_{2} \mathrm{O} 100^{\circ} \mathrm{C}$ & $6 \mathrm{mmol} \mathrm{L}^{-1} \mathrm{HClO}_{4}$ & Shodex KC $811300 \times 8.0 \mathrm{~mm}, 7 \mu \mathrm{m} 50^{\circ} \mathrm{C}, \mathrm{UV} \lambda 210$ & [348] \\
\hline \multicolumn{5}{|c|}{ Ion Exclusion-Based Analysis } \\
\hline Drinks & $\begin{array}{l}\text { Filtration, heat-aided } \\
\text { degassing }\end{array}$ & $\begin{array}{l}\text { Precondition: } 10 \mathrm{mmol} \mathrm{L}^{-1} \mathrm{SDS} 3 \\
\text { h } 0.3 \mathrm{~mL} \mathrm{~min}^{-1} \\
\text { Elution: } 1.84 \mathrm{mmol} \mathrm{L}^{-1} \mathrm{H}_{2} \mathrm{SO}_{4} \\
\text { pH } 2.43\end{array}$ & Kinetex XB-C ${ }_{18} 150 \times 4.6 \mathrm{~mm}, 2.6 \mu \mathrm{m}, \mathrm{UPLC}-\mathrm{UV} \lambda 210 \mathrm{~nm}$ & [349] \\
\hline
\end{tabular}

Mihaljević and coworkers separated organic acids in wine. Organic acid profile (especially glucuronic and galacturonic acids levels) was able to distinguish among Traminer vs. Welsch produced Croatian wines. Mobile phase rate was reduced during chromatography when target acids were glucuronic, gluconic, galactaric, and galacturonic [346]. Diacids and citric acid considerably differ structurally (e.g., number of carbons). Meanwhile, the reduction of flow rate responds to the subtle differences among these intimately related structures, making them more difficult to resolve. Sánchez-Machado and coworkers preserved shrimp tissue through fermentation with lactic acid bacteria. A complete separation of lactic, citric and acetic acid was accomplished. Sonication time and initial sample mass were optimized during the assay [347]. Finally, though most of the tests regarding organic acids extraction-wise are straightforward, even in brightly colored samples (e.g., fruits [350]), still SPE cleanup has been applied, with adequate recoveries, to these extracts to remove interferences as anthocyanins and carbohydrates that may co-elute during acid analysis (especially relevant if a non-selective detector is used) [345].

\subsubsection{Ion Exclusion Chromatography Analysis in Foods}

Fasciano and coworkers modified a reverse phase column, a $\mathrm{C}_{18}$ column was dynamically modified by running a solution of SDS through the column (Table 15). They separated organic acids after optimizing sulfuric acid concentration, flow rate, and $\mathrm{pH}$; an example of how a reverse column can be made more versatile. A wide array of compounds in juices and sodas were analyzed using ion exclusion chromatography [349]. For a detailed description of ion exclusion chromatography, we encourage the reader to pay special attention to this paper introduction.

\subsubsection{Silages}

The maturity of the crop governs silage quality at harvest. However, fermentation in the silo further influences the nutritive value of silage. Coblentz and Akins recently published a detailed discussion of silages [351]. Similarly, Khan and coworkers wrote a more specific review based on maize silages [352]. In both papers, references to silage quality based on organic acids are 
mentioned. Since silage is the result of this fermentation process, the organic acid analysis is used to monitor its quality. Concentrations of fermentation acids do not seem closely related to silage intake; however, they are decisive in the balance of volatile fatty acids produced in the rumen. In turn, affecting gluconeogenic metabolism and influencing milk and body composition in productive livestock. Several researchers have dedicated efforts to not only assess organic acid concentrations from silages but also have studied the effect that organic acid has on silage fermentation. For example, Ke and coworkers included malic or citric acid at concentrations of 0.1 to $0.5 \mathrm{~g} / 100 \mathrm{~g}$ during alfalfa ensiling of alfalfa and concluded that these levels improved silage fermentation quality [348]. Additionally, both acids can be further used as feed additives that have proven to promote animal performance. Silva and coworkers determined the fermentation profile of alfalfa silages treated with microbial inoculants at different fermentation periods under tropical conditions [353]. From the strains tested P. pentosaceus showed the most efficiency suggesting its use as a silage inoculant. The sample pretreatment just consisted of extract acidification with metaphosphoric acid, gravity-aided filtration, and centrifugation.

\subsubsection{Method Application Experience}

We have used ligand exchange-based analysis to routinely screen silage quality (Figure 10). Sample pretreatment consists of metaphosphoric acid extraction. We also have taken advantage of sample extraction for ammoniacal nitrogen (a modified version of method 941.04). In this type of columns, poly and diacids are eluted first. Monocarboxylic acids will elute later on during the chromatographic run in order of increasing alkyl chain length (i.e., formic, acetic, propionic, butyric). Finally, we have used liquid chromatography coupled with a variable wavelength detector set at $210 \mathrm{~nm}$, a Hi-Plex H $(300 \times 7.7 \mathrm{~mm}$ and $8 \mu \mathrm{m}$ particle size $)$ column kept at $60{ }^{\circ} \mathrm{C}$, and a $50 \mathrm{mmol}$ $\mathrm{L}^{-1} \mathrm{H}_{2} \mathrm{SO}_{4}$ solution with a flow rate of $0.6 \mathrm{~mL} \mathrm{~min}^{-1}$ to monitor ammonium propionate, added as a preservative, in dry dog foods (see for example, [354]). Average concentrations of (693.12 \pm 75.63 ) $\mathrm{mg} \mathrm{kg}^{-1}$ have been obtained for local products. Sieved (at $0.5 \mathrm{~mm}$ particle size) dog food was treated with hot water to extract the propionate quantitatively. Both RID and UV detectors can be used for both organic acid and sugar (and alcohol) analysis. Using RID will enable the user to monitor all the compounds above simultaneously, but RID detectors suffer from low sensitivity when compared to others.
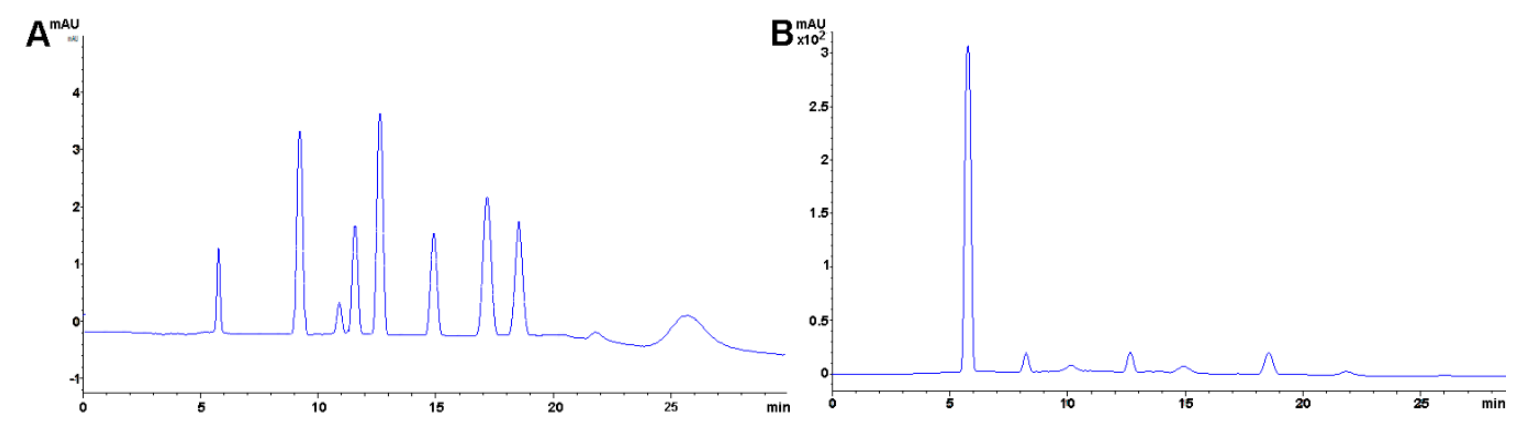

Figure 10. Chromatographs of (A) Mix of organic acid standards malic acid (9.24 min) methanoic acid (formic acid, $10.92 \mathrm{~min}$ ), ethanoic acid (acetic acid, $11.65 \mathrm{~min}$ ), propanoic acid (propionic acid, $12.62 \mathrm{~min}$ ), lactic acid (14.92 min), 2-methylpropanoic acid (isobutyric acid, $17.22 \mathrm{~min}$ ), butanoic acid (butyric acid, $18.52 \mathrm{~min}$ ). (B) A silage sample after extraction with acid $0.01 \mathrm{~mol} \mathrm{~L}^{-1} \mathrm{H}_{2} \mathrm{SO}_{4}$. Fermentation products identified at $18.499 \mathrm{~min}, 14.903 \mathrm{~min}, 12.606 \mathrm{~min}$. The signal at ca. $5.70 \mathrm{~min}$ corresponds to the solvent front.

\subsection{Vitamins}

Vitamins are essential micronutrients that humans and animals need for normal metabolism. The lack of these nutrients in dietary sources can cause serious disease; trace amounts of these 
compounds are required for growth and reproduction. Based on their solubility, vitamins have been divided into two groups: those soluble in organic non-polar solvents and water-soluble vitamins. Thus, the vitamins from the B-complex and vitamin C are classified water soluble while the fat-soluble vitamins are isoprenoid compounds, namely vitamins $\mathrm{A}, \mathrm{D}, \mathrm{E}$ and $\mathrm{K}$. This last group is found in small amounts on foodstuffs, associated with lipids; stored in the liver and fatty tissues, and are eliminated slower than water-soluble vitamins [45].

\subsubsection{Fat-Soluble Vitamins}

Vitamin A is commonly expressed as retinol equivalents but can occur in different chemical forms, i.e., retinal, retinoic acid and retinyl esters. In foods, it is very common to find this vitamin as retinyl esters, more specifically, as acetate, propionate, or palmitate [355]. This vitamin is involved in immune function, vision, reproduction, and cellular communication [356]. Vitamin $\mathrm{E}$ is a term used to designate some related compounds as tocopherols and tocotrienols, it is found in fat products of vegetal origin, mainly oils. The most common tocopherols that can be found in food and feed are $\alpha / \beta / \delta / \gamma$-tocopherol in different proportion. Mixed tocopherols are considered the most effective lipid-soluble antioxidants [357]. Vitamin $\mathrm{D}$ is naturally present in very few foods like sea products, eggs, meat, and dairy products, the most commonly found members are vitamin $D_{2}$ and $D_{3}$, but it is also produced endogenously when ultraviolet rays from sunlight strike the skin and trigger vitamin D synthesis from 7-dehydrocholesterol [358]. It promotes the absorption of calcium, regulates bone growth and plays a role in immune function [359]. Lastly, vitamin $\mathrm{K}$ is an essential nutrient for animals and humans because it is required for functioning of the blood clotting cascade [360], just as vitamin $\mathrm{D}$, vitamin $\mathrm{K}$ can be found in two forms i.e., phylloquinone (vitamin $\mathrm{K}_{1}$, found in green plant leaves e.g., spinach, collards, lettuce, and broccoli [361]) and menaquinone (vitamin $\mathrm{K}_{2}$, bacterium residing in the vertebrate intestine [362]).

Since these compounds are involved in metabolic pathways, and are paramount in health promotion in animals and humans, it is crucial to determine their content in food and feed to comply with daily requirements and quality control. That is why several studies have been conducted regarding the extraction and quantitative analysis of these vitamins, either individually or simultaneously [359,363-382].

\section{Sample Preparation}

Most of the analytical methods involve previous steps of sample preparation like saponification, solid-liquid or liquid-liquid extractions, followed by a concentration step before HPLC analysis (Table 16). The sample pre-treatment is critical for an accurate method. That is why there are many aspects that need to be controlled, Qian and Sheng have studied seven different variables to take into account for simultaneous analysis of vitamins in animal feed. These variables were related to the extraction procedure: (1) sample particle size, (2) solvent, (3) the ratio of sample to solvent, (4) extraction with and without $\mathrm{N}_{2}$ protection, (5) extraction time, (6) equipment and (7) the use of SPE for cleanup [367]. They evaluated how each of the variables affected both the coefficient of variation and the recovery of each of the vitamins in order to obtain extraction conditions that would allow them to satisfy each of the vitamins in a satisfying way. 
Table 16. Determination of fat vitamins and in foods and feeds.

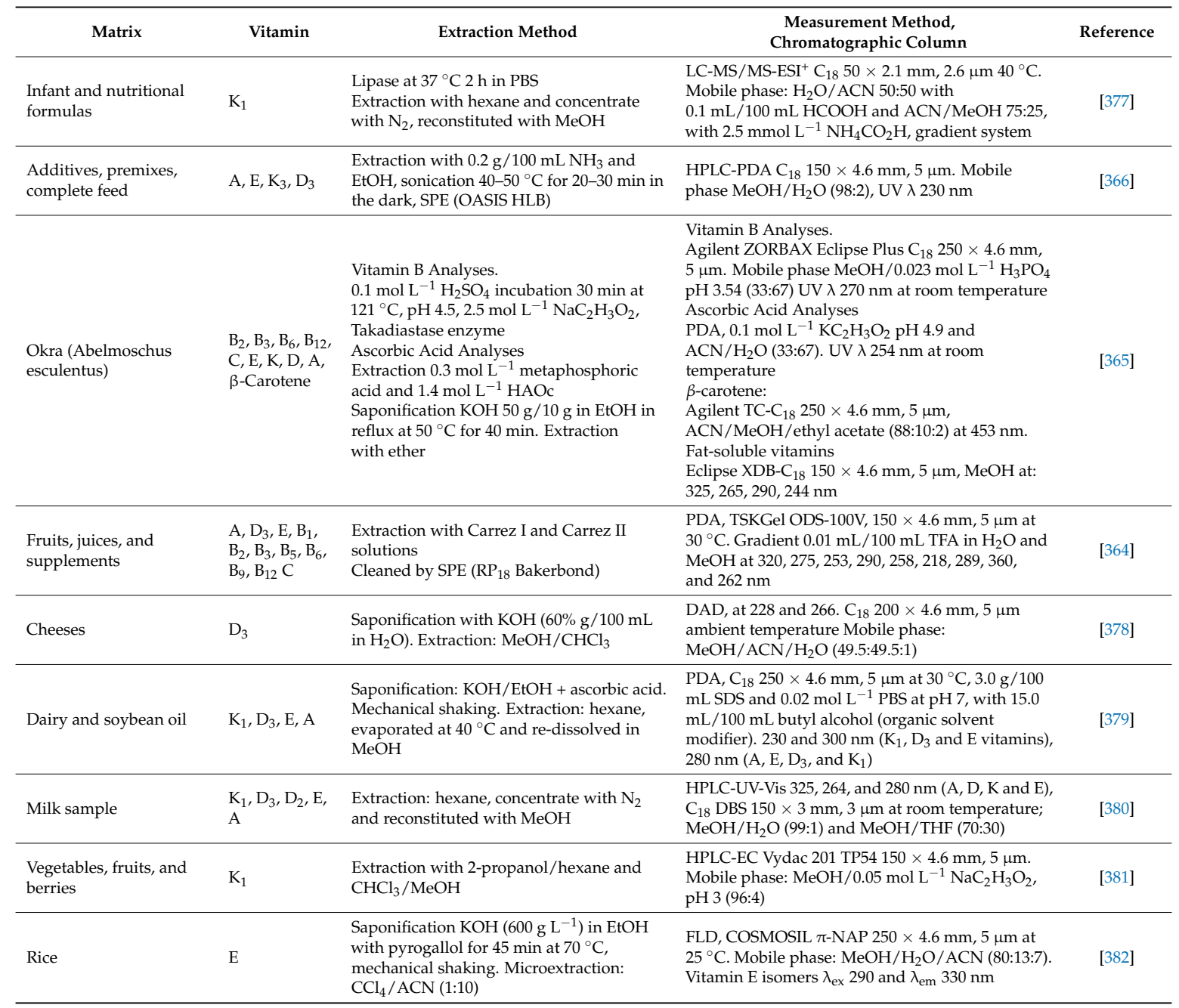

Regarding the first variable in meals and flours, subsample variability and homogeneity is closely linked to particle size. Qian and Sheng observed that large sample particle size causes an incomplete vitamin A extraction with high variability [367]. We have noted that for fresh products, with a total fat content greater than $10 \mathrm{~g} / 100 \mathrm{~g}$ and high moisture content (i.e., greater than $85 \%$ ) (e.g., avocado (Persea americana Mill.) and peach palm (Bactris gasipaes Kunth)), it is advisable to freeze dry the sample, before analysis, to promote homogenization and eliminate water that interferes with fat-soluble compound extraction.

Qian and Sheng developed the assay procedure without saponification, but nevertheless it is a widespread procedure used in the analysis of vitamins since it is an efficient way of removing interferences of lipid origin that can be found in the matrix [363,365,368,374,378,379,382]. Since it is based on an alkaline digestion (i.e., heated $\mathrm{KOH}$ or $\mathrm{NaOH}$ aqueous or alcoholic solutions) there is a disadvantage, the saponification could generate oxidation of the vitamins, which translate into a loss for vitamin degradation and low recovery percentage [366,368]. Some researchers have made use of the antioxidant ability of some compounds such as BHT, BHA, TBHQ, ascorbic acid or pyrogallol to reduce oxidation losses [363,365,367,368,371,374,379,380]. Nevertheless, saponification procedures take time, and the extractions procedures are not always straightforward, because emulsions are generated, as Lim and co-worker mentioned in their comparison of extraction methods for determining tocopherols in soybeans [369], these inconveniences introducing considerable variation, low recovery, and reproducibility, situations that we have also seen in the development of this type of methodologies. 
Recently, alternatives to saponification process for the extraction of vitamins have been used, some papers use enzyme-catalyzed hydrolysis and alcoholysis of ester bonds in vitamin A and E esters to facilitate their determination in milk powder and infant formula. They assayed six lipase preparations and one esterase preparation using diisopropyl ether, hexanes/ethanol and supercritical $\mathrm{CO}_{2}$ containing ethanol. Three of the lipases' preparations from Candida antarctica (Novozyme 435), Rhizomucor miehei (Lipozyme IM) and Pseudomonas cepacia, showed considerably higher activity toward retinyl palmitate but there was no observed activity with $\alpha$-tocopheryl acetate [372]. In feed, Xue and co-workers applied enzymolysis instead of saponification with a basic proteinase named Savinase in $30 \mathrm{~min}$ of incubation time at $40{ }^{\circ} \mathrm{C}$ getting good results in the determination of four fat-soluble vitamins $\left(\mathrm{K}_{3}, \mathrm{~A}, \mathrm{D}_{3}, \mathrm{E}\right)$ [366].

With respect to the solvent type and ratio solvent: sample, there is a wide variety of solvents available for the fat-soluble extraction, most of the methods use solvents such as hexane, heptane, chloroform, dichloromethane, ethyl acetate, tetrahydrofuran, ethyl ether, and the choice will depend on the type of matrix to work with (Table 16). For example, in the case of animal feed [367], a poor resolution was observed using hexane and chloroform, generating an overestimation of vitamin $\mathrm{D}$, such mixture does not allow a good separation during centrifugation which produced a high \%RSD.

If a mixture of acetone $/ \mathrm{CHCl}_{3}(30: 70)$ is used, the results in terms of variability and recovery of vitamins are outstanding, mainly for vitamin A. In low-fat matrices (less than $0.1 \mathrm{~g} / 100 \mathrm{~g}$, e.g., fruit juices), this solvent system has the disadvantage of generating emulsions and, hence, low recoveries. In the case of dairy and infant formulas where the presence of milk proteins is a hindrance, the extraction of the lipid part has been reported using saponification and extraction with hexane, leading to vitamin degradation in fat. It is also an extensive process [373,374]. For this reason, a group of researchers developed a fat extraction methodology using a mixture of $\mathrm{CH}_{2} \mathrm{Cl}_{2}$ : $\mathrm{EtOH}$ 2:1 and separation at $4{ }^{\circ} \mathrm{C}$ with a centrifuge, giving satisfactory results for analysis of FAMES so it could be applied in the extraction of vitamins in these matrices [375].

Regarding extraction time and equipment, Qian and Sheng used vortex mixer for several minutes, rotatory mixer and supersonic mixer, these last two methods were not as effective for extraction of vitamin A and other vitamins due to low recoveries [367]. Hung used a rotatory mixer for extraction of vitamins $\mathrm{D}_{2}$ and $\mathrm{D}_{3}$ during one hour [376]. We have found, that for foodstuffs, the most efficient sample treatment is to rely on the combination of a vortex mixer for one minute, a rotatory mixer for $30 \mathrm{~min}$ or supersonic mixer for $15 \mathrm{~min}$.

Effective extraction can be aided if the solvent contains a percentage of an appropriate antioxidant. $\mathrm{N}_{2}$ has been used in some protocols to the protection [377,380], of extracted vitamins from degradation because the solvent vapor that replaces air over the surface of extraction mixture has a protective antioxidant effect [367]. Qian and Sheng showed evidence that this protection did not influence in the mean values of vitamins A, D, and E and pro-vitamin D, but decreased the variation coefficient [367].

\section{Chromatographic Analysis}

The analytical method for the determination of vitamins in food and feed, is liquid chromatography (HPLC or UPLC) due to its, selectivity, short time of analysis, and high resolution. Methods based on chromatography can be easily automated and can determine several compounds at the same time.

Methods range from using normal phase chromatography with silica columns to reverse phase chromatography with $\mathrm{C}_{8}, \mathrm{C}_{18}$, and $\mathrm{C}_{30}$ columns (Table 16). Lee and coworkers studied three different columns to separate vitamin $\mathrm{A}$ and $\mathrm{E}$ : an $\mathrm{NH}_{2}$ column, $\mathrm{C}_{30}$, and $\mathrm{C}_{18}$. Concerning the resolution, they observed the $\beta$-tocopherol and $\gamma$-tocopherol peaks of vitamin $E$ were not separated and appeared as a single overlapping peak when using a $\mathrm{C}_{18}$, but it could be separated using an $\mathrm{NH}_{2}$ column. Regarding detection and quantification limits the $\mathrm{NH}_{2}$ column presented values lower than $\mathrm{C}_{8}$ column but higher than $\mathrm{C}_{18}$. 
The solvent systems to use as mobile phase vary depending on the selected approach, in the case of normal phase chromatography the solvents systems mostly used are 2-propanol/hexane in different proportion, but also can be use methanol/hexane/THF (97.25:2.5:0.25), or hexane/MTBE (96:4) [374]. In reverse phase the most common are $\mathrm{MeOH}-\mathrm{H}_{2} \mathrm{O}, \mathrm{MeOH}-\mathrm{ACN}$, both techniques can be used in gradient o isocratic mode.

As mentioned before, the liquid chromatography technique has a wide variety of monitoring techniques including PDA, FLD, ECD, ELSD or MSD. The most commonly used detector for vitamins is FLD, which is considerably more sensitive and selective than UV. Therefore, it is possible to carry out a simultaneous determination of vitamin $\mathrm{A}$ and $\mathrm{E}$, for which a programming of the equipment is required so that at certain time intervals it uses the excitation wavelength $\left(\lambda_{\mathrm{ex}}\right)$ and emission wavelength $\left(\lambda_{\mathrm{em}}\right)$ specifies for each vitamin, for vitamin $\mathrm{E}, \lambda_{\mathrm{ex}}=285$ and $\lambda_{\mathrm{em}}=310 \mathrm{~nm}$, for vitamin $\mathrm{A}$ the configuration at $\lambda_{\mathrm{ex}}=325$ and $\lambda_{\mathrm{em}}=470 \mathrm{~nm}$, but no other vitamins could be detected such as $\mathrm{K}$ or D. Alternatively, PDA can work with multiple UV wavelengths and determine the four vitamins at the same time. Mass spectrometry coupled chromatography is usually the most versatile option. However, it requires that the laboratory has the resources for its acquisition. We have successfully applied mass spectrometry to assess tocopherols in feed supplements and animal biological samples (Figure 11A-F).
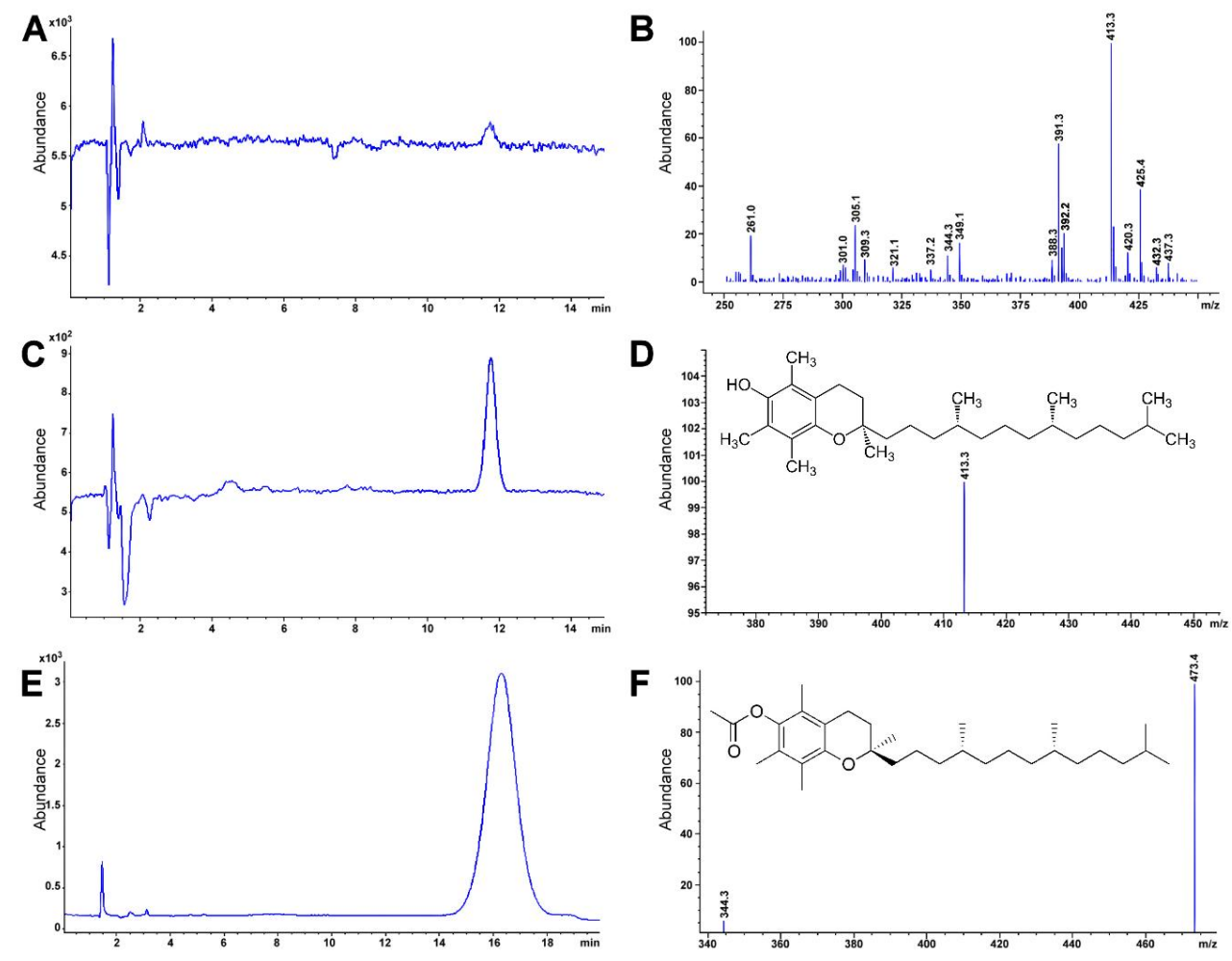

Figure 11. Single quadrupole LC/MS ESI ${ }^{+}$chromatographs of (A) Total ion chromatogram $\alpha$-tocopherol (a $1 \mathrm{mg} \mathrm{L}^{-1}$ solution in butanol) signal positively identified at $11.75 \mathrm{~min}$ (B) Mass spectra for $\alpha$-tocopherol (a $1 \mathrm{mg} \mathrm{L}^{-1}$ solution in butanol) using a cone energy of $120 \mathrm{~V}$ extracted from a signal with a retention time of $11.71 \mathrm{~min}(\mathrm{C}) \alpha$-tocopherol (retention time $11.77 \mathrm{~min}$ ) identified in a chicken plasma sample after extraction with chloroform and butanol (D) $\alpha$-tocopherol in selected ion monitoring (SIM) mode using a cone energy of $120 \mathrm{~V}$ extracted from signal with a retention time of $11.82 \mathrm{~min}(\mathrm{E})$. $\alpha$-tocopherol acetate in an injectable vitamin $\mathrm{E}$ solution for veterinary use using a "dilute and shoot" approach (16.32 $\mathrm{min}$ ), and (F) $\alpha$-tocopherol acetate in SIM mode using a cone energy of $60 \mathrm{~V}$ extracted from signal with a retention time of $16.34 \mathrm{~min}$. 


\subsubsection{Hydrosoluble Vitamins}

One of the main issues that the hydrosoluble vitamins analysis exhibit is that each molecule is structurally different. Hence, to assess each vitamin, different conditions must be applied to the HPLC system to assess each vitamin. Kim published a paper in which ion pairing chromatography was used to monitor six different vitamins (nicotinic acid, nicotinamide, folic acid, and pyridoxine) in the feed [383]. Sodium hexanosulfate was used to with this approach; all six vitamins can be quantified using the same chromatographic run (using the same wavelength and column for all species) (Figure 12).
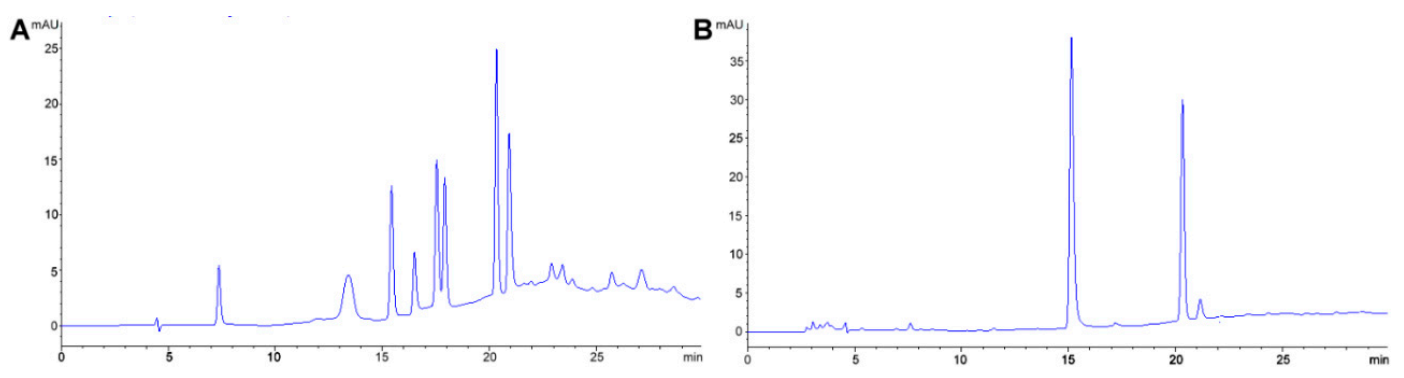

Figure 12. Hydrosoluble vitamin analysis based on ion pairing [383]. (A) Successful separation of 7 complex $B$ vitamins including niacin (nicotinic acid, $B_{3}, 6.67 \mathrm{~min}$ ), FMN ( $\mathrm{B}_{2}, 14.12 \mathrm{~min}$ ), pyridoxal $\left(\mathrm{B}_{6}, 17.007 \mathrm{~min}\right)$, pyridoxamine $\left(\mathrm{B}_{6}, 18.607 \mathrm{~min}\right)$, pyridoxine $(\mathrm{B} 6,19.963 \mathrm{~min})$, folic acid $(\mathrm{B} 9,20.630 \mathrm{~min})$, and thiamine $\left(B_{1}, 25.074 \mathrm{~min}\right)$. (B) Analysis of a vitamin premix destined for feed formulation. Another advantage presented is that the separation can be performed using a reverse phase $\mathrm{C}_{18}$ column.

A usual problem that arises with the analysis of this compounds is the fact that $\mathrm{pH}$ changes affect their chemical behavior drastically both during extraction and chromatographic separation. The author circumvented this issue using a mobile phase and sample extraction solution spiked with $0.1 \mathrm{~mL} / 100 \mathrm{~mL}$ acetic acid, maintaining all species protonated. Midttun and coworkers described an extensive two-phase analysis based on an LC-MS/MS (to determine fat soluble and water soluble). In the chloroform/isooctane phase all-trans retinol, 25-hydroxyvitamin $\mathrm{D}_{2}$, 25 -hydroxyvitamin $D_{3}, \alpha$-tocopherol, $\gamma$-tocopherol, and phylloquinone were retained. The hydrophilic phase (in which water-soluble vitamins were found), was mixed with ethanol, water, pyridine, and methyl chloroformate as a derivatizing agent. In this assay there can be a third phase (i.e., the methyl chloroformate fraction) that it is reserved for gas chromatography analysis of amino acids [384]. As an excellent example of hydrosoluble vitamins analysis using LC-MS/MS in the food industry, is the determination of 15 compounds in beverages using a multi-mode column (SM- $\mathrm{C}_{18}$ column, $150 \times 2.0 \mathrm{~mm}, 3 \mu \mathrm{m}$; Imtakt Co., Kyoto, Japan), which provided reverse-phase, anion- and cation-exchange capacities, and therefore improved the retention of highly polar analytes such as water-soluble vitamins. The use of this column removes the need for an ion pair reagent in the mobile phase [385]. Finally, we encourage the reader toward a recent and ample review regarding fat- and hydrosoluble vitamins, respectively [386,387].

\subsubsection{Method Application Experience}

In our experience in the development of a methodology for the determination of fat-soluble vitamins in food matrices, the most challenging part has been the sample pretreatment. As mentioned above, several factors have to be considered. For the species retinyl acetate and palmitate, we chose to use a direct extraction to avoid decomposition by the saponification process. Extraction can be performed with hexane, ethyl acetate or chloroform; as the last solvent is far easier to eliminate, during concentration steps, is considered the most suitable option. Isopropanol is a useful solvent for reconstitution. 
This method applies to dry matrices as flour, bakery products, freeze-dried pulps or fortified sugar. In the case of dairy products, we highly recommend the use of dichloromethane/ethanol. Separation is carried out using an HPLC-DAD set at $325 \mathrm{~nm}$ and a Zorbax Eclipse XDB- $\mathrm{C}_{8}(150 \times 4.6 \mathrm{~mm}, 5 \mu \mathrm{m})$ column at $50{ }^{\circ} \mathrm{C}$. Shifting the solvent system form a MeOH/ $\mathrm{H}_{2} \mathrm{O}$ (90:10) to $\mathrm{MeOH} / 2$-propanol/ACN (95:1.5:3.5) saves up to $5 \mathrm{~min}$ of chromatographic run time and better peak shape, for the palmitate, is obtained (Figure 13A,B).
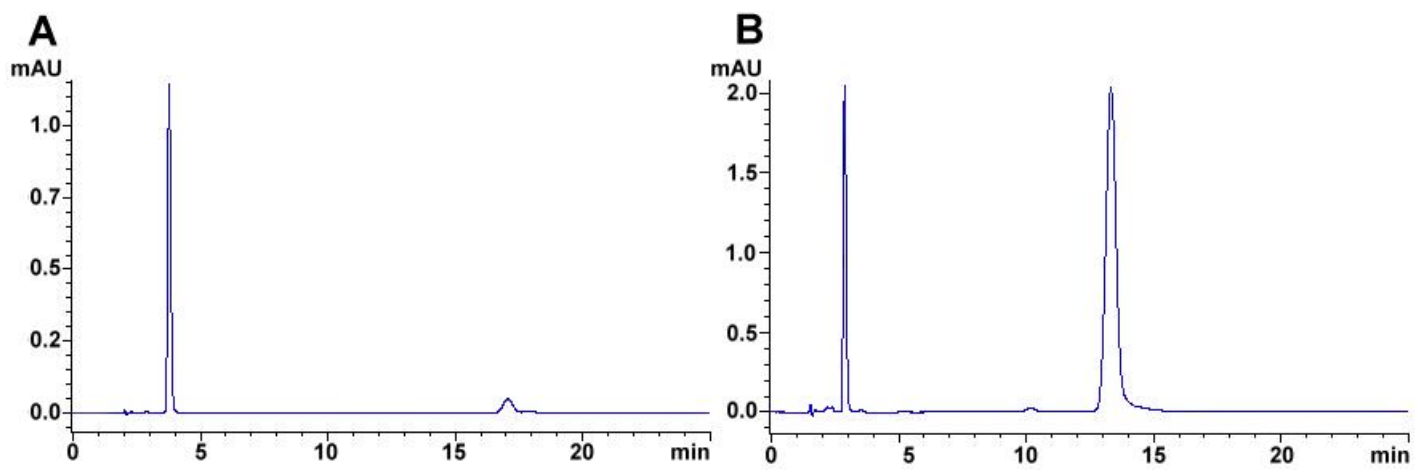

Figure 13. Chromatographs for vitamin A standards mixtures separated with $C_{8}$ column at $325 \mathrm{~nm}$ and $50{ }^{\circ} \mathrm{C}$, of (A) retinyl acetate (3.11 min) and retinyl palmitate (17.63 min) using $\mathrm{MeOH} / \mathrm{H}_{2} \mathrm{O}(90: 10)$ and (B) retinyl acetate (2.89 $\mathrm{min}$ ) and retinyl palmitate $(13.30 \mathrm{~min})$ using $\mathrm{MeOH} / 2$-propanol/acetonitrile (95:1.5:3.5).

Monitoring the analytes at $295 \mathrm{~nm}$, using $\mathrm{MeOH} / \mathrm{H}_{2} \mathrm{O}$ (90:10) as solvents at a flow rate of

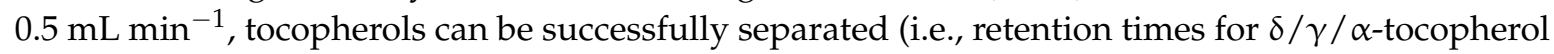
$5.35,6.03$ and $8.59 \mathrm{~min}$, respectively; $\left.R_{s} 1.97\right)$. In samples with relatively high-fat content, saponification is necessary to eliminate interferences that usually share similar retention times that those for $\alpha$-tocopherol. Food and feed samples can be fortified or can naturally contain both, vitamin $\mathrm{D}_{2}$ and $\mathrm{D}_{3}$. Therefore, for a method to be suitable, simultaneous detection of both analytes is a must. Under the conditions above, $\mathrm{C}_{8}$ stationary phases are incapable of resolving both species.

A $\mathrm{C}_{18}$ column heated at $30^{\circ} \mathrm{C}$ and a $\mathrm{MeOH} / 2$-propanol/ACN (90:3:7) solvent system, with a flow set at $0.3 \mathrm{~mL} \mathrm{~min}^{-1}$, can achieve a resolution of 1.25 (Figure 14A,B). Though a mobile phase composed $\mathrm{MeOH}$ and $\mathrm{H}_{2} \mathrm{O}$ is highly desirable, a drawback using this solvent system in complex matrices is that $\alpha$-tocopherol can be interference for the identification of vitamin $D_{3}$ and vice versa (Figure $14 \mathrm{C}$ ). A solvent gradient, a column with longer alkyl chains (e.g., $\mathrm{C}_{30}$ ) or the use an MS detector may be employed to solve this issue. 

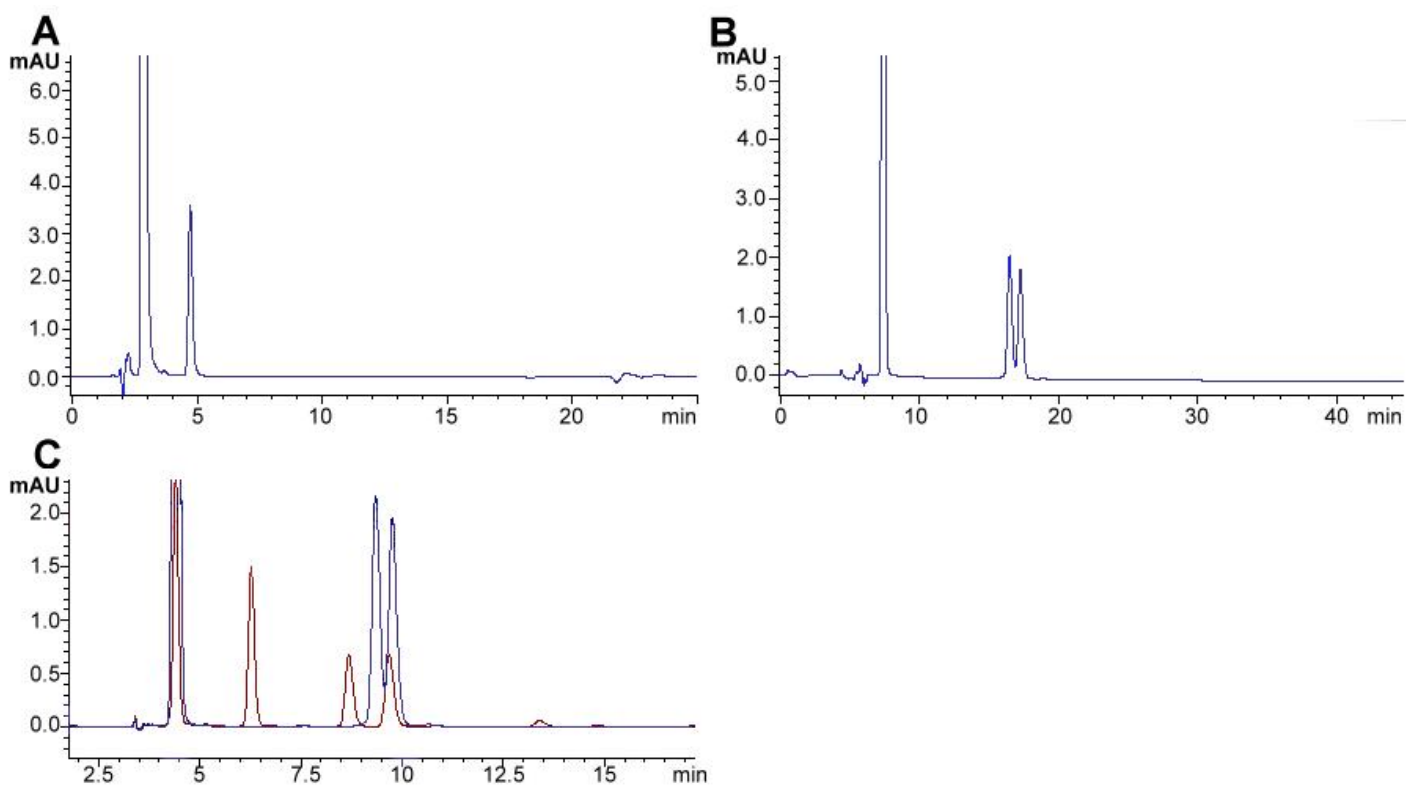

Figure 14. Separation for vitamin $\mathrm{D}_{2}+\mathrm{D}_{3}$ standards at $264 \mathrm{~nm}$ using $(\mathrm{A})$ a $\mathrm{C}_{8}$ column and (B) a $\mathrm{C}_{18}$ column $\mathrm{D}_{2}(16.47 \mathrm{~min})$ y $\mathrm{D}_{3}(17.24 \mathrm{~min})$. Analysis performed at $30^{\circ} \mathrm{C}$ using $\mathrm{MeOH} / 2$-propanol/ $\mathrm{ACN}$ (90:3:7) (C) Superposed chromatograms for vitamin $\mathrm{D}_{2}+\mathrm{D}_{3}$ (blue line) and $\delta / \gamma / \alpha$-tocopherol standards using a $\mathrm{C}_{18}$ column and $\mathrm{MeOH} / \mathrm{H}_{2} \mathrm{O}(90: 10), 30{ }^{\circ} \mathrm{C}$.

\section{Conclusions}

LC is a powerful and versatile tool for food and feeds analysis, food and feed matrices are complex mixtures that on occasion present to the researcher difficulties as analytes of interest must be extracted and purified before injecting into the LC system. Advantages that chromatography provides when applied to food or feed analysis include sensitivity (determination of trace amounts, especially important in the case of contaminants, residues, controlled or undesired substances), automation and high throughput (reducing time and user dependence in laboratories with considerable workloads), simultaneous determination of multiple analytes. Food and feed chemists must make an effort to develop methods that provide a faster response and with few possible numbers of steps. Several current methods that are based on other step-full or less automated, or specific techniques can be reinvented, transformed and transplanted to LC analysis to improve sensitivity, specificity, and selectivity (For example, exchanging a spectrophotometric-based piperine analysis for a chromatography one). Within the myriad of alternatives, the LC approach delivers, each on its own seldom can solve a research problem, and each technique (i.e., each detector, each chromatographic column or sample treatment) has its shortcomings and limits as to which data is to provide. Usually, a multiphasic methodology is desirable to reach an appropriate conclusion. Hence, LC methods are more useful when are tailored to fit a purpose. Nowadays, mass spectrometry coupled liquid chromatography is an almost widespread technique that can provide molecule confirmation, ease trace analysis and allows the assay of multiple analytes simultaneously. Not only is a versatile tool for routine analysis but, research-wise, it provides more information about the target molecules and opens a valuable doorway toward a myriad of applications in food analysis including metabolomics, proteomics, and parvomics. Notwithstanding, as demonstrated above, traditional detectors are still the most commonly available in most laboratories. With a proper 
sample pretreatment, some traditional-detector-based methods are, regarding analytical performance, comparable to those based on MS.

Author Contributions: Conceptualization: C.C.-H and F.G.-C.; Methodology: C.C.-H, G.A., F.G.-C., A.L.; Software: F.G.-C.; Investigation: C.C.-H, G.A., F.G.-C., A.L.; Resources: C.C.-H, G.A., F.G.-C., A.L.; Data Curation: F.G.-C.; Writing—original draft preparation: C.C.-H, G.A., F.G.-C., A.L., C.C.-H, G.A., F.G.-C., A.L.; Visualization: F.G.-C..; Supervision: F.G.-C, G.A; Funding Acquisition: C.C.-H.

Funding: This research was funded by the University of Costa Rica grants number A2502, B2062, B2066, B2659, B8042, B5084. B3097, ED-427 and ED-428 and the APC was funded by the Office of the Vice Provost for Research of the University of Costa Rica.

Acknowledgments: Marelyn Rojas Lezama is acknowledged for her help doing the experiments regarding nitrate and nitrite in the hay. Special thanks to Guy Lamoureux Lamontagne for his suggestions.

Conflicts of Interest: The authors declare no conflict of interest.

\section{References}

1. Ercsey-Ravasz, M.; Toroczkai, Z.; Lakner, Z.; Baranyu, J. Complexity of the international agro-food trade network and its impact on food safety. PLoS ONE 2012, 7, e37810. [CrossRef]

2. Fair, K.R.; Bauch, C.T.; Anand, M. Dynamics of the Global Wheat Trade Network and Resilience to Shocks. Sci. Rep. 2017, 7, 7177. [CrossRef] [PubMed]

3. Keding, G.B.; Schneider, K.; Jordan, I. Production and processing of foods as core aspects of nutrition-sensitive agriculture and sustainable diets. Food Secur. 2013, 5, 825-846. [CrossRef]

4. Canady, R.; Lane, R.; Paoli, G.; Wilson, M.; Bialk, H.; Hermansky, S.; Kobielush, B.; Li, J.-E.; Llewellyn, C.; Scimeca, J. Determining the applicability of threshold of toxicological concern approaches to substances found in foods. Crit. Rev. Food Sci. Nutr. 2013, 53, 1239-1249. [CrossRef] [PubMed]

5. Van der Fels-Klerx, H.J.; Adamse, P.; de Jong, J.; Hoogenboom, R.; de Nijs, M.; Bikker, P. A model for risk-based monitoring of contaminants in feed ingredients. Food Control 2017, 72, 211-218. [CrossRef]

6. Allard, D.G. The 'farm to plate' approach to food safety_Everyone's business. Can. J. Infect. Dis. 2002, 13, 185-190. [CrossRef]

7. Kniel, K.E.; Kumar, D.; Thakur, S. Understanding the complexities of food safety using a "One Health" approach. Microbiol. Spectr. 2018, 6. [CrossRef]

8. Krska, R.; de Nijs, M.; McNerney, O.; Pichler, M.; Gilbert, J.; Edwards, S.; Suman, M.; Magan, N.; Rossi, V.; van der Fels-Klerx, H.J.; et al. Safe food and feed through an integrated toolbox for mycotoxin management: The MyToolBox approach. World Mycotoxin J. 2016, 9, 487-495. [CrossRef]

9. Wartella, W.A.; Lichtenstein, A.H.; Boon, C.S. Front-of-Package Nutrition Rating Systems and Symbols; Institute of Medicine of the National Academies Press: Washington, DC, USA, 2010; ISBN 978-0-309-15827-5.

10. Association of American Feed Control Officials (AAFCO). Pet feed regulation. In AAFCO Official Publication; AAFCO: Atlanta, GA, USA, 2018.

11. Yashin, Y.I.; Yashin, A.Y. Analysis of food products and beverages using high-performance liquid chromatography and ion chromatography with electrochemical detectors. J. Anal. Chem. 2004, 59, 1237-1243. [CrossRef]

12. Nollet, L.M.L. Liquid chromatography in food analysis. In Encyclopedia of Analytical Chemistry; Meyers, R.A., McGorrin, R.J., Eds.; John Wiley and Sons: Hoboken, NJ, USA, 2006. [CrossRef]

13. Quitmann, H.; Fan, R.; Czermak, P. Acidic organic compounds in beverage, food, and feed production. In Biotechnology of Food and Feed Additives; Zorn, H., Czermak, P., Eds.; Springer: Berlin/Heidelberg, Germany, 2014; ISBN 978-3-662-43760-5.

14. Jiang, J.; Xiong, Y.L. Natural antioxidants as food and feed additives to promote health benefits and quality of meat products: A review. Meat Sci. 2016, 120, 107-117. [CrossRef] [PubMed]

15. Candan, T.; Bağdatl, A. Use of natural antioxidants in poultry meat. CBU J. Sci. 2017, 13, 279-291.

16. Chanadang, S.; Koppel, K.; Aldrich, G. The impact of rendered protein meal oxidation level on shelf-life, sensory characteristics, and acceptability in extruded pet food. Animals 2016, 6, 44. [CrossRef] [PubMed]

17. Sanches-Silva, A.; Costa, D.; Alburquerque, T.G.; Buonocore, G.G.; Ramos, F.; Castilho, M.C.; Machado, A.V.; Costa, H.S. Trends in the use of natural antioxidants in active food packaging: A review. Food Addit. Contam. Part A 2014, 31, 374-395. [CrossRef] [PubMed] 
18. Erickson, M.C.; Doyle, M.P. The challenges of eliminating or substituting antimicrobial preservatives in foods. Annu. Rev. Food Sci. Technol. 2017, 8, 371-390. [CrossRef]

19. Gupta, C.; Prakash, D.; Gupta, S. A biotechnological approach to microbial based perfumes and flavours. J. Microbiol. Exp. 2015, 2. [CrossRef]

20. Das, A.; Chakraborty, R. An introduction to sweeteners. In Sweeteners, Reference Series in Phytochemistry; Mérillon, J.-M., Ramawat, K.G., Eds.; Springer International Publishing: Basel, Switzerland, 2018; ISBN 978-3-319-27026-5.

21. Mooradian, A.D.; Smith, M.; Tokuda, M. The role of artificial and natural sweeteners in reducing the consumption of table sugar: A narrative review. Clin. Nutr. ESPEN 2017, 18, 1-8. [CrossRef]

22. Durán, S.; Dávila, L.A.; Contreras, M.C.E.; Rojas, D.; Costa, J. Noncaloric sweeteners in children: A controversial theme. BioMed Res. Int. 2018, 2018, 4806534.

23. Subedi, B.; Kannan, K. Fate of Artificial Sweeteners in Wastewater Treatment Plants in New York State, USA. Environ. Sci. Technol. 2014, 48, 13668-13674. [CrossRef]

24. Khan, S.A. Artificial sweeteners: Safe or unsafe? J. Pak. Med. Assoc. 2015, 25, 225-227.

25. García-Almeida, J.M.; Conejo-Pareja, I.M.; Muñoz-Garach, A.; Gómez-Pérez, A.; García-Alemán, J. Sweeteners: Regulatory Aspects. In Sweeteners, Reference Series in Phytochemistry; Mérillon, J.-M., Ramawat, K.G., Eds.; Springer International Publishing: Basel, Switzerland, 2016; ISBN 978-3-319-27026-5.

26. Shah, R.; de Jager, L.S. Recent analytical methods for the analysis of sweeteners in food: A regulatory perspective. Food Drug Adm. Papers 2017, 5, 13-31.

27. Sharma, A.; Amarnath, S.; Thulasimani, M.; Ramaswamy, S. Artificial sweeteners as a sugar substitute: Are they really safe? Indian J. Pharmacol. 2016, 48, 237-240. [CrossRef] [PubMed]

28. Vanĕk, T.; Nepovím, A.; Valíček, P. Determination of stevioside in plant material and fruit teas. J. Food Compos. Anal. 2001, 14, 383-388. [CrossRef]

29. Chaturvedula, V.S.P.; Zamora, J. Reversed-Phase HPLC analysis of steviol glycosides isolated from Stevia rebaudiana Bertoni. Food Nutr. Sci. 2014, 5, 1711-1716. [CrossRef]

30. Wang, T.-H.; Avula, B.; Tang, W.; Wang, M.; Elsohly, M.A.; Khan, I.A. Ultra-HPLC method for quality and adulterant assessment of steviol glycosides sweeteners-Stevia rebaudiana and stevia products. Food Addit. Contam. Part A 2015, 32, 674-685.

31. Martono, Y.; Riyanto, S.; Rohman, A.; Martono, S. Improvement method of fast and isocratic RP-HPLC analysis of major diterpene glycoside from Stevia rebaudiana leaves. AIP Conf. Proc. 2016, 1755, 080001-080008.

32. Sádecka, J.; Polonský, J. Determination of inorganic ions in food and beverages by capillary electrophoresis. J. Chromatogr. 1999, 834, 401-417. [CrossRef]

33. Rios, R.V.; Pessanha, M.D.F.; de Almeida, P.F.; Viana, C.L.; Lannes, S.C. Application of fats in some food products. Food Sci. Technol. 2014, 34, 3-15. [CrossRef]

34. Li, H.; Zhou, X.; Gao, P.; Li, Q.; Li, H.; Huang, R.; Wu, M. Inhibition of lipid oxidation in foods and feeds and hydroxyl radical treated fish erythrocytes: A comparative study of Ginkgo biloba leaves extracts and synthetic antioxidants. Anim. Nutr. 2016, 2, 234-241. [CrossRef]

35. Kerr, B.J.; Kellner, T.A.; Shurson, G.C. Characteristics of lipids and their feeding value in swine diets. J. Anim. Sci. Biotechnol. 2015, 6, 30. [CrossRef]

36. Shurson, G.C.; Kerr, B.J.; Hanson, A.R. Evaluating the quality of feed fats and oils and their effects on pig growth performance. J. Anim. Sci. Biotechnol. 2015, 6, 10. [CrossRef]

37. Pickova, J. Importance of knowledge on lipid composition of foods to support development towards consumption of higher levels of n-3 fatty acids via freshwater fish. Psychol. Res. 2009, 58, S39-S45.

38. Benkerroum, N. Biogenic amines in dairy products: Origin, incidence, and control means. Compr. Rev. Food Sci. Food Saf. 2016, 15, 801-826. [CrossRef]

39. Spano, G.; Russo, P.; Lonvaud-Funel, A.; Lucas, P.; Alexandre, H.; Grandvalet, C.; Coton, E.; Coton, M.; Barnavon, L.; Bach, B.; et al. Biogenic amines in fermented foods. Eur. J. Clin. Nutr. 2010, 64, S95-S100. [CrossRef] [PubMed]

40. Landete, J.M.; Ferrer, S.; Polo, L.; Pardo, I. Biogenic amines in wines from three Spanish regions. J. Agric. Food Chem. 2005, 53, 1119-1124. [CrossRef]

41. Biji, K.B.; Ravishankar, C.N.; Venkateswarlu, R.; Mohna, C.O.; Srinivasa, T.K. Biogenic amines in seafood: A review. J. Food Sci. Technol. 2016, 53, 2210-2218. [CrossRef] [PubMed] 
42. Karau, A.; Grayson, I. Amino acids in human and animal nutrition. Adv. Biochem. Eng. Biotechnol. 2014, 143, $189-228$. [PubMed]

43. Hardy, K.; Brand-Miller, J.; Brown, K.D.; Thomas, M.G.; Copeland, L. The importance of dietary carbohydrate in human evolution. Q. Rev. Biol. 2015, 90, 251-268. [CrossRef] [PubMed]

44. Bach Knudsen, K.E.; Lærke, H.N.; Ingerslev, A.K.; Hedemann, M.S.; Nielsen, T.S.; Theil, P.K. Carbohydrates in pig nutrition-Recent advances. J. Anim. Sci. 2016, 94, 1-11. [CrossRef]

45. McDowell, L.R. Vitamins in Animal and Human Nutrition; Iowa State University Press: Ames, IA, USA, 2000; pp. 15-217. ISBN 0-8138-2630-6.

46. Koleva, I.I.; van Beek, T.A.; Soffers, A.E.M.F.; Dusemund, B.; Rietjens, I.M.C.M. Alkaloids in the human food chain-Natural occurrence and possible adverse effects. Mol. Nutr. Food Res. 2012, 56, 30-52. [CrossRef]

47. Di Lorenzo, C.; Dos Santos, A.; Colombo, F.; Moro, E.; Dell'Agli, M.; Restani, P. Development and validation of HPLC method to measure active amines in plant food supplements containing Citrus aurantium L. Food Control 2014, 46, 136-142. [CrossRef]

48. Endlová, L.; Laryšová, A.; Vrbovsky, V.; Navrátilová, Z. Analysis of alkaloids in poppy straw by high-performance liquid chromatography. IOSR J. Eng. 2015, 3, 1-7.

49. Arai, K.; Terashima, H.; Aizaewa, S.; Taga, A.; Yamamoto, A.; Tsutsumiuchi, K.; Kodama, S. Simultaneous Determination of Trigonelline, Caffeine, Chlorogenic Acid and Their Related Compounds in Instant Coffee Samples by HPLC Using an Acidic Mobile Phase Containing Octanesulfonate. Anal. Sci. 2015, 31, 831-835. [CrossRef] [PubMed]

50. Wang, H.-B.; Qi, W.; Zhang, L.; Yuan, D. Qualitative and quantitative analyses of alkaloids in Uncaria species by UPLC-ESI-Q-TOF/MS. Chem. Pharm. Bull. 2014, 62, 1100-1109. [CrossRef] [PubMed]

51. Ramdani, D.; Chaudhry, A.S.; Seal, C.J. Alkaloid and polyphenol analysis by HPLC in green and black tea powders and their potential use as additives in ruminant diets. AIP Conf. Proc. 2018, 1927, 0300081-0300086.

52. Yashin, A.; Yashin, Y.; Xia, X.; Nemzer, B. Chromatographic Methods for Coffee Analysis: A Review. J. Food Res. 2017, 6, 60-82. [CrossRef]

53. Pereira, C.A.M.; Rodrigues, T.R.; Yariwake, J.H. Quantification of Harman alkaloids in sour passion fruit pulp and seeds by a novel dual SBSE-LC/Flu (stir bar sorptive extraction-liquid chromatography with fluorescence detector) method. J. Braz. Chem. Soc. 2014, 25, 1472-1483. [CrossRef]

54. Kowalczyk, E.; Patyra, E.; Grelik, A.; Kwiatek, K. Development and validation of an analytical method for determination of ergot alkaloids in animal feedingstuffs with high performance liquid chromatography-fluorescence detection. Pol. J. Vet. Sci. 2016, 19, 559-565. [CrossRef]

55. Upadhyay, V.; Sharma, N.; Joshi, H.M.; Malik, A.; Mishra, M.; Singh, B.P.; Tripathi, S. Development and validation of rapid RP-HPLC method for estimation of piperine in Piper nigrum L. Int. J. Herb. Med. 2013, 1, 6-9.

56. Granados-Chinchilla, F; Rodriguez, C. Tetracyclines in food and feedingstuffs: From regulation to analytical methods, bacterial resistance, and environmental and health implications. J. Anal. Methods Chem. 2017, 2017, 1315497. [CrossRef]

57. Alshannaq, A.; Yu, J.-H. Occurrence, toxicity, and analysis of major mycotoxins in food. Int. J. Environ. Res. Public Health 2017, 14, 632. [CrossRef]

58. Granados-Chinchilla, F.; Molina, A.; Chavarría, G.; Alfaro-Cascante, M.; Bogantes-Ledezma, D.; Murillo-Williams, A. Aflatoxins occurrence through the food chain in Costa Rica: Applying the One Health approach to mycotoxin surveillance. Food Control 2017, 82, 217-226. [CrossRef]

59. Oliveira, F.A.; Pereira, E.N.C.; Gobbi, J.M.; Soto-Blanco, B.; Melo, M.M. Multiresidue method for detection of pesticides in beef meat using liquid chromatography coupled to mass spectrometry detection (LC-MS) after QuEChERS extraction. Food Addit. Contam. Part A 2018, 35, 94-109. [CrossRef] [PubMed]

60. Schnabel, K.; Schmitz, R.; von Soosten, D.; Frahm, J.; Kersten, S.; Meyer, U.; Breves, G.; Hackenberg, R.; Spitzke, M.; Dänicke, S. Effects of glyphosate residues and different concentrate feed proportions on performance, energy metabolism and health characteristics in lactating dairy cows. Arch. Anim. Nutr. 2017, 71, 413-427. [CrossRef] [PubMed]

61. Velkoska-Markovska, L.; Petanovska-Ilievska, B.; Markovski, A. Application of high performance liquid chromatography to the analysis of pesticide residues in apple juice. Contemp. Agric. 2018, 67, 93-102. [CrossRef]

62. Recjczak, T.; Tuzimski, T. Application of high-performance liquid chromatography with diode array detector for simultaneous determination of 11 synthetic dyes in selected beverages and foodstuffs. Food Anal. Methods 2017, 10, 3572-3588. [CrossRef] 
63. Shehata, A.B.; Rizk, M.S.; Rend, E.A. Certification of caffeine reference material purity by ultraviolet/visible spectrophotometry and high-performance liquid chromatography with diode-array detection as two independent analytical methods. J. Food Drug Anal. 2016, 24, 703-715. [CrossRef] [PubMed]

64. Cancho Grande, B.; Falcón, M.S.G.; Comesaña, M.R.; Gándara, J.S. Determination of sulfamethazine and trimethoprim in liquid feed premixes by HPLC and diode array detection, with an analysis of the uncertainty of the analytical results. J. Agric. Food Chem. 2001, 49, 3145-3150. [CrossRef]

65. Barbosa, J.; Moura, S.; Barbosa, R.; Ramos, F.; Silveira, M.I. Determination of nitrofurans in animal feeds by liquid chromatography-UV photodiode array detection and liquid chromatography-ionspray tandem mass spectrometry. Anal. Chim. Acta 2007, 586, 359-365. [CrossRef]

66. Horigome, J.; Kozuma, M.; Shirasaki, T. Fluorescence pattern analysis to assist food safety-Food analysis technology driven by fluorescence fingerprints. Hitachi Rev. 2016, 65, 248-253.

67. Borràs, S.; Companyó, R.; Guiteras, J. Analysis of sulfonamides in animal feeds by liquid chromatography with fluorescence detection. J. Agric. Food Chem. 2011, 59, 5240-5247. [CrossRef]

68. Patyra, E.; Kwiatek, K. Determination of fluoroquinolones in animal feed by ion pair high-performance liquid chromatography with fluorescence detection. Anal. Lett. 2017, 50, 1711-1720. [CrossRef]

69. Wacoo, A.P.; Wendiro, D.; Vuzi, P.C.; Hawumba, J.F. Methods for Detection of Aflatoxins in Agricultural Food Crops. J. Appl. Chem. 2014, 2014, 70629. [CrossRef]

70. Shuib, N.S.; Makahleh, A.; Salhimi, S.M.; Saad, B. Determination of aflatoxin $\mathrm{M}_{1}$ in milk and dairy products using highperformance liquid chromatography-fluorescence with post column photochemical derivatization. J. Chromatogr. A 2017, 1510, 51-56. [CrossRef] [PubMed]

71. González de la Huebra, M.J.; Vincent, U.; von Holst, C. Sample preparation strategy for the simultaneous determination of macrolide antibiotics in animal feedingstuffs by liquid chromatography with electrochemical detection (HPLC-ECD). J. Pharm. Biomed. Anal. 2007, 43, 1628-1637. [CrossRef] [PubMed]

72. Gazdik, Z.; Ztka, O.; Petrlova, J.; Adam, V.; Zehnalek, J.; Horna, A.; Reznicek, V.; Beklova, M.; Kizek, R. Determination of vitamin C (ascorbic acid) using high performance liquid chromatography coupled with electrochemical detection. Sensors 2008, 8, 7097-7112. [CrossRef]

73. Başaran, U.; Akkbik, M.; Mut, H.; Gülümser, E.; Doğrusöz, M.C.; Koçoğlu, S. High-Performance liquid chromatography with refractive index detection for the determination of inulin in chicory roots. Anal. Lett. 2018, 51, 83-95. [CrossRef]

74. Kupina, S.; Roman, M. Determination of total carbohydrates in wine and wine-like beverages by HPLC with a refractive index detector: First action 2013.12. J. AOAC Int. 2014, 97, 498-505. [CrossRef]

75. Zhang, J.; Zhu, Y. Determination of betaine, choline and trimethylamine in feed additive by ion-exchange liquid chromatography/non-suppressed conductivity detection. J. Chromatogr. A 2007, 1170, 114-117. [CrossRef]

76. Wei, D.; Xang, X.; Wang, N.; Zhu, Y. A rapid ion chromatography column-switching method for online sample pretreatment and determination of L-carnitine, choline and mineral ions in milk and powdered infant formula. RSC Adv. 2017, 7, 5920-5927. [CrossRef]

77. Troise, A.D.; Fiore, A.; Fogliano, V. Quantitation of acrylamide in foods by high-resolution mass spectrometry. J. Agric. Food Chem. 2014, 62, 74-79. [CrossRef]

78. Patyra, E.; Nebot, C.; Gavilán, R.E.; Cepeda, A.; Kwiatek, K. Development and validation of an LC-MS/MS method for the quantification of tiamulin, trimethoprim, tylosin, sulfadiazine and sulfamethazine in medicated feed. Food Addit. Contam. Part A 2018, 35, 882-891. [CrossRef] [PubMed]

79. Wang, K.; Lin, K.; Huang, X.; Chen, M. A simple and fast extraction method for the determination of multiclass antibiotics in eggs using LC-MS/MS. Journal of Agricultural and Food Chemistry. J. Agric. Food Chem. 2017, 65, 5064-5073. [CrossRef] [PubMed]

80. Winkler, J.; Kersten, S.; Valenta, H.; Meyer, U.; Engelhardt, U.H.; Dänicke, S. Development of a multi-toxin method for investigating the carryover of zearalenone, deoxynivalenol and their metabolites into milk of dairy cows. Food Addit. Contam. Part A 2015, 32, 371-380.

81. Botha, C.J.; Legg, M.J.; Truter, M.; Sulyok, M. Multitoxin analysis of Aspergillus clavatus-infected feed samples implicated in two outbreaks of neuromycotoxicosis in cattle in South Africa. Onderstepoort J. Vet. Res. 2014, 81, e1-e6. [CrossRef] [PubMed] 
82. Granados-Chinchilla, F.; Artavia, G. A straightforward LC approach using an amine column and single quad mass detector to determine choline chloride in feed additives and feeds. MethodsX 2017, 4, $297-304$. [CrossRef] [PubMed]

83. Nassar, A.-E.F.; Bjorge, S.M. On-Line liquid chromatography-accurate radioisotope counting coupled with a radioactivity detector and mass spectrometer for metabolite identification in drug discovery and development. Anal. Chem. 2003, 75, 785-790. [CrossRef] [PubMed]

84. Kim, H.J.; Bae, I.K.; Jeong, M.H.; Park, H.J.; Jung, J.S.; Kim, J.E. A new HPLC-ELSD method for simultaneous determination of $N$-acetylglucosamine and $N$-acetylgalactosamine in dairy foods. Int. J. Anal. Chem. 2015, 2015, 892486. [CrossRef]

85. Yan, W.; Wang, N.; Zhang, P.; Zhang, J.; Wu, S.; Zhu, Y. Simultaneous determination of sucralose and related compounds by high-performance liquid chromatography with evaporative light scattering detection. Food Chem. 2016, 204, 358-364. [CrossRef]

86. Wang, Y.; Wang, M.J.; Li, J.; Yao, S.C.; Xue, J.; Zou, W.B.; Hu, C.Q. determination of spectinomycin and related substances by HPLC coupled with evaporative light scattering detection. Acta Chromatogr. 2015, 207, 93-109. [CrossRef]

87. Ligor, M.; Studzińska, S.; Horna, A.; Buszewski, B. Corona-charged aerosol detection: An analytical approach. Crit. Rev. Anal. Chem. 2013, 43, 64-78. [CrossRef]

88. Vehovec, T.; Obreza, A. Review of operating principle and applications of the charged aerosol detector. J. Chromatogr. A 2010, 1217, 1549-1556. [CrossRef]

89. Grembecka, M.; Lebiedzińska, A.; Szefer, P. Simultaneous separation and determination of erythritol, xylitol, sorbitol, mannitol, maltitol, fructose, glucose, sucrose and maltose in food products by high performance liquid chromatography coupled to charged aerosol detector. Microchem. J. 2014, 117, 77-82. [CrossRef]

90. Szekeres, A.; Budai, A.; Bencsik, O.; Németh, L.; Bartók, T.; Szécsi, Á.; Mesterházy, Á.; Vágvölgyi, C. Fumonisin measurement from maize samples by high-performance liquid chromatography coupled with corona charged aerosol detector. J. Chromatogr. Sci. 2014, 52, 1181-1185. [CrossRef]

91. Enri, F.; Steuer, W.; Bosshart, H. Automation and validation of HPLC-Systems. Chromatographia 1987, 24, $201-207$.

92. Oláh, E.; Tarnai, M.; Fekete, J. Possibility of large volume injection and band focusing in UHPLC. J. Chromatogr. Sci. 2013, 51, 839-844. [CrossRef] [PubMed]

93. Williamson, G. The role of polyphenols in modern nutrition. Nutr. Bull. 2017, 42, 226-235. [CrossRef]

94. Pandey, K.B.; Rizvi, S.I. Plant polyphenols as dietary antioxidants in human health and disease. Oxidaive Med. Cell. Longev. 2009, 2, 270-278. [CrossRef] [PubMed]

95. Beaulieu, M.; Franke, K.; Fischer, K. Feeding on ripening and over-ripening fruit: Interactions between sugar, ethanol and polyphenol contents in a tropical butterfly. J. Exp. Biol. 2017, 220, 3127-3134. [CrossRef]

96. Vanholme, R.; Demedts, B.; Morreel, K.; Ralph, J.; Boerjan, W. Lignin Biosynthesis and Structure. Plant Physiol. 2010, 153, 895-905. [CrossRef]

97. Bensalem, J.; Dal-Pen, A.; Gillard, E.; Fréderic, C.; Pallet, V. Protective effects of berry polyphenols against age-related cognitive impairment. Nutr. Aging 2015, 3, 89-106. [CrossRef]

98. Kowalska, K.; Olejnik, A.; Szwajgier, D.; Olkowicz, M. Inhibitory activity of chokeberry, bilberry, raspberry and cranberry polyphenol-rich extract towards adipogenesis and oxidative stress in differentiated 3T3-L1 adipose cells. PLOS ONE 2017, 12, e0188583. [CrossRef] [PubMed]

99. Khalifa, I.; Zhu, W.; Li, K.-K.; Li, C.-M. Polyphenols of mulberry fruits as multifaceted compounds: Compositions, metabolism, health benefits, and stability-A structural review. J. Funct. Foods 2018, 40, $28-43$. [CrossRef]

100. Pérez-Jiménez, J.; Neveu, V.; Vos, F.; Sclbert, A. Identification of the 100 richest dietary sources of polyphenols: An application of the Phenol-Explorer database. Eur. J. Clin. Nutr. 2010, 64, S112-S120. [CrossRef] [PubMed]

101. Acosta, O.; Vaillant, F.; Pérez, A.M.; Dornier, M. Concentration of polyphenolic compounds in blackberry (Rubus adenotrichos Schltdl) juice by nanofiltration. J. Food Process Eng. 2017, 40, e12343. [CrossRef]

102. Haminiuk, C.W.; Maciel, G.M.; Plata-Oviedo, M.S.V.; Peralta, R.M. Phenolic compounds in fruits-An overview. Int. J. Food Sci. Technol. 2012, 47, 2023-2044. [CrossRef]

103. Karasawa, M.M.G.; Mohan, C. Fruits as Prospective Reserves of bioactive Compounds: A Review. Nat. Prod. Bioprospect. 2018, 8, 335-346. [CrossRef]

104. Reynoso-Camacho, R.; Rufino, M.S.M.; Amaya-Cruz, D.M.; Pérez, A.M. Non-extractable polyphenols in tropical fruits: Occurrence and health-related properties. In Non-extractable Polyphenols and Carotenoids: 
Importance in Human Nutrition and Health; Saura-Calixto, F., Pérez-Jiménez, J., Eds.; Royal Society of Chemistry: Cambridge, UK, 2018; ISBN 978-1-78801-106-8.

105. Abbas, M.; Saeed, F.; Anjum, F.M.; Afzaal, M.; Tufail, T.; Bashir, M.S.; Ishtiaq, A.; Hussain, S.; Suleria, H.A. Natural polyphenols: An overview. Int. J. Food Prop. 2016, 20, 1689-1699. [CrossRef]

106. Kaşikci, M.B.; Bağdatlioğlu, N. High hydrostatic pressure treatment of fruit, fruit products and fruit juices: A review on phenolic compounds. J. Food Health Sci. 2016, 2, 27-39.

107. Miletić, N.; Mitrović, O.; Popović, B.; Nedović, V.; Zlatković, B.; Kandić, M. Polyphenolic content and antioxidant capacity in fruits of plum (Prunus domestica L.) cultivars "Valjevka" and "Mildora" as influenced by air drying. J. Food Qual. 2013, 36, 229-237. [CrossRef]

108. McSweeny, M.; Seetharaman, K. State of polyphenols in the drying process of fruits and vegetables. Crit. Rev. Food Sci. Nutr. 2015, 55, 660-669. [CrossRef]

109. Koffi, E.; Sea, T.; Dodehe, Y.; Soro, S. Effect of solvent type on extraction of polyphenols from twenty three Ivorian plants. J. Anim. Plant Sci. 2010, 5, 550-558.

110. Flores, G.; Dastmalchi, K.; Wu, S.-B.; Whalen, K.; Dabo, A.J.; Reynertson, K.A.; Foronjy, R.F.; D'Armiento, J.M.; Kennelly, E.J. Phenolic-rich extract from the Costa Rican Guava (Psidium friedrichsthalianum) pulp with antioxidant and anti-inflammatory activity. Potential for COPD therapy. Food Chem. 2013, 141, 889-895. [CrossRef] [PubMed]

111. Tresserra-Rimbau, E.; Arranz, S.; Vallverdu-Queralt, A. New Insights into the Benefits of Polyphenols in Chronic Diseases. Oxidative Med. Cell. Longev. 2017, 2017, 1432071. [CrossRef] [PubMed]

112. Yang, J.; Dwyer, J. Exploring Possible Health Effects of Polyphenols in Foods. Nutr. Today 2017, 52, 62-72. [CrossRef]

113. Gordon, A.; Jungfer, E.; da Silva, B.A.; Maia, J.G.S.; Marx, F. Phenolic constituents and antioxidant capacity of four underutilized fruits from the Amazon region. J. Agric. Food Chem. 2011, 59, 7688-7699. [CrossRef] [PubMed]

114. Assefa, A.D.; Jeong, Y.-J.; Kim, D.-J.; Jeon, Y.-A.; Ok, H.-C.; Baek, H.-J.; Sung, J.-S. Characterization, identification, and quantification of phenolic compounds using UPLC-Q-TOF-MS and evaluation of antioxidant activity of 73 Perilla frutescens accessions. Food Res. Int. 2018, 111, 153-167. [CrossRef]

115. Anton, D.; Bender, I.; Kaart, T.; Roasto, M.; Heinonen, M. Changes in polyphenols contents and antioxidant capacities of organically and conventionally cultivated tomato (Solanum lycopersicum L.) fruits during ripening. Int. J. Anal. Chem. 2017, 2017, 2367453. [CrossRef]

116. Radovanović, B.C.; Anđelković, A.S.M.; Radovanović, A.B.; Anđelković, M.Z. Antioxidant and antimicrobial activity of polyphenol extracts from wild berry fruits grown in southeast Serbia. Trop. J. Pharm. Res. 2013, 12, 813-819. [CrossRef]

117. Veljković, J.N.; Pavlović, A.N.; Mitić, S.S.; Tošić, S.B.; Stojanović, G.S.; Kaličanin, B.M.; Stanović, D.M.; Stojković, M.B.; Mitić, M.N.; Brcanović, J.M. Evaluation of individual phenolic compounds and antioxidant properties of black, green, herbal and fruit tea infusions consumed in Serbia: Spectrophotometrical and electrochemical approaches. J. Food Nutr. Res. 2013, 52, 12-24.

118. Miletić, N.; Popović, B.; Mitrović, O.; Kandić, M.; Leposavić, A. Phenolic compounds and antioxidant capacity of dried and candied fruits commonly consumed in Serbia. Czech J. Food Sci. 2014, 32, 360-368. [CrossRef]

119. Rojas-Garbanzo, C.; Zimmermann, B.F.; Schulze-Kaysers, N.; Schieber, A. Characterization of phenolic and other polar compounds in peel and flesh of pink guava (Psidium guajava L. cv. 'Criolla') by ultra-high performance liquid chromatography with diode array and mass spectrometric detection. Food Res. Int. 2017, 100, 445-453. [CrossRef] [PubMed]

120. Azofeifa, G.; Quesada, S.; Pérez, A.M.; Vaillant, F.; Michel, A. Effect of an in vitro digestion on the antioxidant capacity of a microfiltrated blackberry juice (Rubus adenotrichos). Beverages 2018, 4, 30. [CrossRef]

121. Georgé, S.; Brat, P.; Alter, P.; Amiot, M.J. Rapid determination of polyphenols and vitamin C in plant derived products. J. Agric. Food Chem. 2005, 53, 1370-1373. [CrossRef] [PubMed]

122. Gouvêa, A.; de Araujo, M.C.; Schulz, D.F.; Pacheco, S.; Godoy, R.; Cabral, L. Anthocyanins standards (cyanidin-3-O-glucoside and cyanidin-3-O-rutinoside) isolation from freeze-dried açaí (Euterpe oleraceae Mart.) by HPLC. Ciênc. Tecnol. Aliment. 2012, 32, 43-46. [CrossRef]

123. Teboukeu, G.B.; Djikeng, F.T.; Klang, M.J.; Ndomou, S.H.; Karuna, M.S.L.; Womeni, H.M. Polyphenol antioxidants from cocoa pods: Extraction optimization, effect of the optimized extract, and 
storage time on the stability on palm olein during thermoxidation. J. Food Process. Preserv. 2018, 42, e13592. [CrossRef]

124. Ryu, W.-K.; Kim, H.-W.; Kim, G.-D.; Rhee, H.-I. Rapid determination of capsaicinoids by colorimetric method. J. Food Drug Anal. 2017, 25, 798-803. [CrossRef]

125. Collins, M.D.; Wasmund, L.M.; Bosland, P.W. Improved method for quantifying capsaicinoids in Capsicum using high-performance liquid chromatography. Hortic. Sci. 1995, 30, 137-139.

126. Guzmán, I.; Bosland, P.W. Sensory properties of chile pepper heat e and its importance to food quality and cultural preference. Appetite 2017, 117, 186-190. [CrossRef]

127. Kobata, K.; Sugawara, M.; Mimura, M.; Yawaza, S.; Watanabe, T. Potent Production of Capsaicinoids and Capsinoids by Capsicum Peppers. J. Agric. Food Chem. 2013, 61, 11127-11132. [CrossRef]

128. Garcés-Claver, A.; Gil-Ortega, R.; Álvarez-Fernández, A.; Arnedo-Andrés, M.S. Inheritance of capsaicin and dihydrocapsaicin, determined by HPLC-ESI/MS, in an intraspecific cross of Capsicum annuum L. J. Agric. Food Chem. 2007, 55, 6951-6957. [CrossRef]

129. Goll, J.; Frey, A.; Minceva, M. Study of the separation limits of continuous solid support free liquid-liquid chromatography: Separation of capsaicin and dihydrocapsaicin by centrifugal partition chromatography. J. Chromatogr. A 2013, 1284, 59-68. [CrossRef] [PubMed]

130. Othman, Z.A.A.; Ahmed, Y.B.H.; Habila, M.A.; Ghafar, A.A. Determination of capsaicin and dihydrocapsaicin in Capsicum fruit samples using high performance liquid chromatography. Molecules 2011, 16, 8919-8929. [CrossRef] [PubMed]

131. Ma, F.; Yang, Q.; Matthäus, B.; Li, P.; Zhang, Q.; Zhang, L. Simultaneous determination of capsaicin and dihydrocapsaicin for vegetable oil adulteration by immunoaffinity chromatography cleanup coupled with LC-MS/MS. J. Chromatogr. B 2016, 1021, 137-144. [CrossRef] [PubMed]

132. Zhou, C.; Ma, D.; Cao, W.; Shi, H.; Jiang, Y. Fast simultaneous determination of capsaicin, dihydrocapsaicin and nonivamide for detecting adulteration in edible and crude vegetable oils by UPLC-MS/MS. Food Addit. Contam. Part A 2018, 35, 1447-1452. [CrossRef] [PubMed]

133. Schmidt, A.; Fiechter, G.; Fritz, E.-M.; Mayer, H.K. Quantitation of capsaicinoids in different chilies from Austria by a novel UPLC method. J. Food Compos. Anal. 2017, 60, 32-37. [CrossRef]

134. Sganzerla, M.; Coutinho, J.P.; Tavares de Melo, A.M.; Godoy, E.T. Fast method of capsaicinoids analysis from Capsicum chinense fruits. Food Res. Int. 2014, 64, 718-725. [CrossRef]

135. Dang, Y.M.; Hong, Y.S.; Lee, C.L.; Khan, N.; Park, S.; Jeong, S.-W.; Kim, K.S. Determination of Capsaicinoids in Red Pepper Products from South Korea by High-Performance Liquid Chromatography with Fluorescence Detection. Anal. Lett. 2018, 51, 1291-1303. [CrossRef]

136. Lu, M.; Ho, C.-T.; Huang, Q. Extraction, bioavailability, and bioefficacy of capsaicinoids. J. Food Drug Anal. 2017, 25, 27-36. [CrossRef] [PubMed]

137. Zhang, Q.; Hu, J.; Sheng, L.; Li, Y. Simultaneous quantification of capsaicin and dihydrocapsaicin in rat plasma using HPLC coupled with tandem mass spectrometry. J. Chromatogr. B 2010, 878, 2292-2297. [CrossRef]

138. Kuzma, M.; Fodor, K.; Maász, G.; Avar, P.; Mózsik, G.; Past, T.; Fischer, E.; Perjési, P. A validated HPLC-FLD method for analysis of intestinal absorption and metabolism of capsaicin and dihydrocapsaicin in the rat. J. Pharm. Biomed. Anal. 2015, 103, 59-66. [CrossRef]

139. Baskaran, P.; Krishnan, V.; Ren, J.; Thyagarjan, B. Capsaicin induces browning of white adipose tissue and counters obesity by activating TRPV1 channel-dependent mechanisms. Br. J. Pharmacol. 2016, 173, 2369-2389. [CrossRef]

140. Wolde, T. Effects of caffeine on health and nutrition: A Review. Food Sci. Qual. Manag. 2014, 30, $59-65$.

141. Martínez-Pinilla, E.; Oñatibia-Asibia, A.; Franco, R. The relevance of theobromine for the beneficial effects of cocoa consumption. Front. Pharmacol. 2015, 6, 1-5. [CrossRef]

142. Ahluwalia, N.; Herrick, K. Caffeine intake from food and beverage sources and trends among children and adolescents in the United States: Review of national quantitative studies from 1999 to 2011. Adv. Nutr. 2015, 6, 102-111. [CrossRef] [PubMed]

143. Verster, J.C.; Koenig, J. Caffeine intake and its sources: A review of national representative studies. Crit. Rev. Food Sci. Nutr. 2018, 58, 1250-1259. [CrossRef] [PubMed] 
144. Li, X.; Simmons, R.; Mwongela, S.M. Two-stage course-embedded determination of caffeine and related compounds by HPLC in caffeine containing food, beverages and (or) related products. J. Lab. Chem. Educ. 2017, 5, 19-25.

145. Lowry, J.A.; Pearce, R.E.; Gaedigk, A.; Venneman, M.; Talib, N.; Shaw, P.; Leeder, J.S.; Kearns, G.L. Lead and its effects on cytochromes P450. J. Drug Metab. Toxicol. 2012, S5, S004. [CrossRef]

146. Grujić-Letić, N.; Rakić, B.; Šefer, E.; Milanović, M.; Nikšić, M.; Vujić, I.; Milić, N. Quantitative determination of caffeine in different matrices. Maced. Pharm. Bull. 2016, 62, 77-84.

147. Gonçalves, E.S.; Rodrigues, S.V.; Vieira da Silva-Filho, E. The use of caffeine as a chemical marker of domestic wastewater contamination in surface waters: Seasonal and spatial variations in Teresópolis, Brazil. Rev. Ambient. Agua 2017, 12, 192-202. [CrossRef]

148. Gliszczyńska-Świglo, A.; Rybicka, I. Simultaneous determination of caffeine and water-soluble vitamins in energy drinks by HPLC with photodiode array and fluorescence detection. Food Anal. Methods 2015, 8, 139-146. [CrossRef]

149. Mazdeh, F.Z.; Moradi, Z.; Moghaddam, G.; Moradi-Khatoonabadi, Z.; Aftabdari, F.E.; Badaei, P.; Hajimahmoodi, M. Determination of synthetic food colors, caffeine, sodium benzoate and potassium sorbate in sports drinks. Trop. J. Pharm. Res. 2016, 15, 183-188. [CrossRef]

150. Ortega, N.; Romero, M.-P.; Macià, A.; Reguant, J.; Anglès, N.; Morelló, J.-R.; Motilva, M.-J. Comparative study of UPLC-MS/MS and HPLC-MS/MS to determine procyanidins and alkaloids in cocoa samples. J. Food Compos. Anal. 2010, 23, 298-305. [CrossRef]

151. Rodríguez-Carrasco, Y.; Gaspari, A.; Graziani, G.; Santini, A.; Ritieni, A. Fast analysis of polyphenols and alkaloids in cocoa-based products by ultra-high performance liquid chromatography and orbitral high resolution mass spectrometry (UHPLC-Q-Orbitrap-MS/MS). Food Res. Int. 2018, 111, 229-236. [CrossRef] [PubMed]

152. Oellig, C.; Schunck, J.; Schwack, W. Determination of caffeine, theobromine and theophylline in Mate beer and Mate soft drinks by high-performance thin-layer chromatography. J. Chromatogr. A 2018, 1533, 208-212. [CrossRef]

153. Alvi, S.N.; Hammami, M.M. Validated HPLC method for determination of caffeine level in human plasma using synthetic plasma: Application to bioavailability studies. J. Chromatogr. Sci. 2011, 49, 292-296. [CrossRef]

154. Begas, E.; Kouvaras, E.; Tsakalof, A.K.; Bounitsi, M.; Asprodini, E.K. Development and validation of a reverse-phase HPLC method for CYP1A2 phenotyping by use of a caffeine metabolite ratio in saliva. Biomed. Chromatogr. 2015, 29, 1657-1663. [CrossRef]

155. Rodríguez, A.; Costa-Bauza, A.; Saenz-Torres, C.; Rodrigo, D.; Grases, F. HPLC method for urinary theobromine determination: Effect of consumption of cocoa products on theobromine urinary excretion in children. Clin. Biochem. 2015, 48, 1138-1143. [CrossRef]

156. Shrestha, S.; Rijal, S.K.; Pokhrel, P.; Rai, K.P. A simple HPLC method for determination of caffeine content in tea and coffee. J. Food Sci. Technol. 2016, 9, 74-78.

157. Fajara, B.E.P.; Susanti, H. HPLC determination of caffeine in coffee beverage. IOP Conf. Ser. Mater. Sci. Eng. 2017, 259, 01211. [CrossRef]

158. Aşçi, B.; Zor, Ş.D.; Dönmez, Ö.A. Development and validation of HPLC method for the simultaneous determination of five food additives and caffeine in soft drinks. Int. J. Anal. Chem. 2016, 2016, 2879406. [CrossRef]

159. Yamamoto, T.; Takahashi, H.; Suzuki, K.; Hirano, A.; Kamei, M.; Goto, T.; Takahashi, N.; Kawada, T. Theobromine enhances absorption of cacao polyphenol in rats. Biosci. Biotechnol. Biochem. 2014, 78, 2059-2063. [CrossRef] [PubMed]

160. Romano, R.; Santini, A.; Le Grottaglie, L.; Manzo, N.; Visconti, A.; Ritieni, A. Identification markers based on fatty acid composition to differentiate between roasted Arabica and Canephora (Robusta) coffee varieties in mixtures. J. Food Compos. Anal. 2014, 35, 1-9. [CrossRef]

161. López-Sánchez, R.C.; Lara-Díaz, V.J.; Aranda-Gutiérrez, A.; Martínez-Cardona, J.A.; Hernández, J.A. HPLC method for quantification of caffeine and its three major metabolites in human plasma using fetal bovine serum matrix to evaluate prenatal drug exposure. J. Anal. Methods Chem. 2018, 2018, 2085059. [CrossRef] [PubMed]

162. Ptolemy, A.S.; Tzioumis, E.; Thomke, A.; Rifai, S.; Kellogg, M. Quantification of theobromine and caffeine in saliva, plasma and urine via liquid chromatography-tandem mass spectrometry: A single analytical protocol applicable to cocoa intervention studies. J. Chromatogr. A 2010, 878, 409-416. [CrossRef] [PubMed] 
163. Kobayashi, J.; Ikeda, K.; Terada, H.; Mochizuki, M.; Sugiyama, H. HPLC determination of caffeine using a photodiode array detector and applying a derivative processing to chromatograms. Bull. Nippon Vet. Life Sci. Univ. 2014, 63, 48-57.

164. Naviglio, D.; Gallo, M.; Le Grottaglie, L.; Scala, C.; Ferrara, L.; Santini, A. Determination of cholesterol in Italian chicken eggs. Food Chem. 2012, 132, 701-708. [CrossRef]

165. Ribeiro, S.M.L.; Luz, S.S.; Aquino, R.S. The role of nutrition and physical activity in cholesterol and aging. Clin. Geriatr. Med. 2015, 31, 401-416. [CrossRef]

166. Albuquerque, T.G.; Oliveira, M.B.P.P.; Sanches-Silva, A.; Costa, H.S. Cholesterol determination in foods: Comparison between high performance and ultra-high performance liquid chromatography. Food Chem. 2016, 193, 18-25. [CrossRef] [PubMed]

167. Gylling, H.; Simonen, P. Are plant sterols and plant stenols are a viable future treatment for dyslipidemia? Expert Rev. Cardiovasc. Ther. 2016, 4, 549-551. [CrossRef] [PubMed]

168. Sonawane, P.D.; Pollier, J.; Panda, S.; Szymanski, J.; Massalha, H.; Yona, M.; Unger, T.; Malitsky, S.; Arendt, P.; Powels, L.; et al. Plant cholesterol biosynthetic pathway overlaps with phytosterol metabolism. Nat. Plants 2016, 3, 16205. [CrossRef] [PubMed]

169. Cruz, R.; Casal, S.; Mendes, E.; Costa, A.; Santos, C.; Morais, S. Validation of a single-extraction procedure for sequential analysis of vitamin E, cholesterol, fatty acids, and total fat in seafood. Food Anal. Methods 2012, 6, 1196-1204. [CrossRef]

170. Saldanha, T.; Bragagnolo, N. Effect of grilling on cholesterol oxide formation and fatty acids alterations in fish. Ciênc. Tecnol. Aliment. 2010, 30, 385-390. [CrossRef]

171. Bauer, L.C.; Santana, D.A.; Macedo, M.S.; Torres, A.G.; de Souza, N.E.; Simionato, J.I. Method validation for simultaneous determination of cholesterol and cholesterol oxides in milk by RP-HPLC-DAD. J. Braz. Chem. Soc. 2014, 25, 161-168. [CrossRef]

172. Daneshfar, A.; Khezeli, T.; Lotfi, H.J. Determination of cholesterol in food samples using dispersive liquid-liquid micro extraction followed by HPLC-UV. J. Chromatogr. B 2009, 877, 456-460. [CrossRef]

173. Georgiou, C.A.; Constantinou, M.S.; Kapnissi-Christodoulou, C.P. Sample preparation: A critical step in the analysis of cholesterol oxidation products. Food Chem. 2014, 145, 1918-1926. [CrossRef]

174. Robinet, P.; Wang, Z.; Hazen, S.L.; Smith, J.D. A simple and sensitive enzymatic method for cholesterol quantification in macrophages and foam cells. J. Lipid Res. 2010, 51, 3364-3369. [CrossRef]

175. Carvalho, P.O.; Campos, P.R.B.; Noffs, M.D.; Fegolente, P.B.L.; Fegolente, L.V. Enzymatic hydrolysis of salmon oil by native lipases: Optimization of process parameters. J. Braz. Chem. Soc. 2009, 20, 117-124. [CrossRef]

176. Codex Alimentarius. Code of Practice for the Prevention and Reduction of Mycotoxin Contamination in Cereals (CAC/RCP 51-2003). 2003. Available online: http:/ / www.fao.org/fao-who-codexalimentarius/ codex-texts/codes-of-practice/es / (accessed on 20 June 2018).

177. Njumbe Ediage, E.; Van Poucke, C.; De Saeger, S. A multi-analyte LC-MS/MS method for the analysis of 23 mycotoxins in different sorghum varieties: The forgotten sample matrix. Food Chem. 2015, 117, 397-404. [CrossRef]

178. Binder, E. Managing the risk of mycotoxins in modern feed production. Anim. Feed Sci. Technol. 2007, 133, $149-166$. [CrossRef]

179. Dzuman, Z.; Zachariasova, M.; Lacina, O.; Veprokova, Z.; Slavokova, P.; Hajslova, J. A rugged high-throughput analytical approach for the determination and quantification of multiple mycotoxins in complex feed matrices. Talanta 2014, 121, 263-272. [CrossRef]

180. Chavarría, G.; Molina, A.; Leiva, A.; Méndez, G.; Wong-González, E.; Cortés-Muñoz, M.; Rodríguez, C.; Granados-Chinchilla, F. Distribution, stability, and protein interactions of Aflatoxin M1 in fresh cheese. Food Control 2017, 73, 581-586. [CrossRef]

181. Ostry, V.; Malir, F.; Toman, J.; Grosse, Y. Mycotoxins as human carcinogens, the IARC Monographs classification. Mycotoxins Res. 2016, 33, 65-73. [CrossRef]

182. CAST. Mycotoxins: Risks in Plant, Animal, and Human Systems; Council for Agricultural Science and Technology: Ames, IA, USA, 2003; pp. 13-48. ISBN 1-887383-22-0.

183. Molina Alvarado, A.; Zamora-Sanabria, R.; Granados-Chinchilla, F. A Focus on Aflatoxins in Feedstuffs: Levels of Contamination, Prevalence, Control Strategies, and Impacts on Animal Health. In Aflatoxin Control, Analysis, Detection and Health Risks; Lukman Bola Abdulra'uf, Ed.; IntechOpen: London, UK, 2017; pp. 115-152. 
184. Codex Alimentarius. Code of Practice for the Reduction of Aflatoxin $B_{1}$ in Raw Materials and Supplemental Feedingstuffs for Milk Producing Animals (CAC/RCP 45-1997). 1997. Available online: http:/ /www.fao. org/fao-who-codexalimentarius/codex-texts/codes-of-practice/es / (accessed on 20 June 2018).

185. Flores-Flores, M.; González-Peñas, E. Development and validation of a high performance liquid chromatographic-mass spectrometry method for the simultaneous quantification of 10 trichothecenes in ultra-high temperature processed cow milk. J. Chromatogr. A 2015, 1419, 37-44. [CrossRef]

186. Njumbe Ediage, E.; Diana Di Mavungu, J.; Monbaliu, S.; Van Peteghem, C.; De Saeger, S. A Validated Multianalyte LC-MS/MS Method for Quantification of 25 Mycotoxins in Cassava Flour, Peanut Cake and Maize Samples. J. Agric. Food Chem. 2011, 59, 5173-5180. [CrossRef] [PubMed]

187. Rasmussen, R.; Storm, I.; Rasmussen, P.; Smedsgaard, J.; Nielsen, K. Multi-mycotoxin analysis of maize silage by LC-MS/MS. Anal. Bioanal. Chem. 2010, 397, 765-776. [CrossRef]

188. Chala, A.; Taye, W.; Ayalew, A.; Krska, R.; Sulyok, M.; Logrieco, A. Multimycotoxin analysis of sorghum (Sorghum bicolor L. Moench) and finger millet (Eleusine coracana L. Gaten) from Ethiopia. Food Control 2014, 45, 29-35. [CrossRef]

189. Vishwanath, V.; Sulyok, M.; Labuda, R.; Bicker, W.; Krska, R. Simultaneous determination of 186 fungal and bacterial metabolites in indoor matrices by liquid chromatography/tandem mass spectrometry. Anal. Bioanal. Chem. 2009, 395, 1355-1372. [CrossRef]

190. Alija, C.M.; Brar, S.K.; Verma, M.; Tyagi, R.D.; Godbout, S.; Valéro, J.R. Bio-processing of agro-byproducts to animal feed. Crit. Rev. Biotechnol. 2012, 32, 382-400.

191. Mikušová, P.; Ritieni, A.; Santini, A.; Juhasová, G.; Šrobárová, A. Contamination by mould of grape berries in Slovakia. Food Addit. Contam. Part A 2010, 27, 738-747. [CrossRef]

192. Santini, A.; Ferracane, R.; Meca, G.; Ritieni, A. Overview of analytical methods for beauvericin and fusaproliferin in food matrices. Anal. Bioanal. Chem. 2009, 395, 1253-1260. [CrossRef]

193. Gil-Serna, J.; Vázquez, C.; González-Jaén, M.T.; Patiño, B. Wine contamination with ochratoxins: A Review. Beverages 2018, 4, 6. [CrossRef]

194. Pizzutti, I.R.; de Kok, A.; Scholten, J.; Righi, L.W.; Cardoso, C.D.; Rohers, G.N.; da Silva, R.C. Development, optimization and validation of a multimethod for the determination of 36 mycotoxins in wines by liquid chromatography-tandem mass spectrometry. Talanta 2014, 129, 352-363. [CrossRef] [PubMed]

195. Nistor, E.; Dobre, A.; Dobre, A.; Bampidis, V.; Ciola, V. Grape pomace in sheep and dairy cows feeding. J. Hortic. For. Biotechnol. 2014, 18, 146-150.

196. Guerra-Rivas, C.; Gallardo, B.; Mantecón, Á.R.; del Álamo-Sanza, M.; Manso, T. Evaluation of grape pomace from red winw by-products as feed for sheep. J. Sci. Food Agric. 2017, 97, 1885-1893. [CrossRef] [PubMed]

197. Kerasioti, E.; Terzopoulou, Z.; Komini, O.; Kafantaris, I.; Makri, S.; Stagos, D.; Gerasopoulos, K.; Anisimov, N.Y.; Tsatsakis, A.M.; Kouretas, D. Tissue specific effects of feeds supplemented with grape pomace or olive oil mill wastewater on detoxification enzymes in sheep. Toxicol. Rep. 2017, 4, 364-372. [CrossRef] [PubMed]

198. Avantaggiato, G.; Greco, D.; Damascelli, A.; Solfrizzo, M.; Visconti, A. Assessment of Multi-mycotoxin Adsorption Efficacy of Grape Pomace. J. Agric. Food Chem. 2014, 62, 497-507. [CrossRef] [PubMed]

199. Gambacorta, L.; Pinton, P.; Avantaggiato, G.; Oswald, I.P.; Solfrizzo, M. Grape Pomace, an Agricultural Byproduct Reducing Mycotoxin Absorption: In Vivo Assessment in Pig Using Urinary Biomarkers. J. Agric. Food Chem. 2016, 64, 6762-6771. [CrossRef]

200. Anadón, A.; Martínez-Larrañaga, M.; Ares, I.; Martínez, M. Chapter 7-Regulatory Aspects for the Drugs and Chemicals Used in Food-Producing Animals in the European Union. In Veterinary Toxicology: Basic and Clinical Principles, 3rd ed.; Gupta, R.C., Ed.; Academic Press: Cambridge, MA, USA, 2018; pp. 103-131.

201. Decheng, S.; Peilong, W.; Yang, L.; Ruiguo, W.; Shulin, W.; Zhiming, X.; Su, Z. Simultaneous determination of antibiotics and amantadines in animal-derived feedstuffs by ultraperformance liquid chromatographic-tandem mass spectrometry. J. Chromatogr. B 2018, 1095, 183-190. [CrossRef]

202. Molognoni, L.; Coelho de Souza, N.; Antunes de Sá Ploêncio, L.; Amadeu Micke, G.; Daguer, H. Simultaneous analysis of spectinomycin, halquizol, zilpaterol, and melamine in feedingstuffs by ion-pair liquid chromatography-tandem mass spectrometry. J. Chromatogr. A 2018, 1569, 110-117. [CrossRef]

203. Cancho Grande, B.; García Falcón, M.S.; Simal Gándara, J. El uso de los antibióticos en la alimentación animal: Perspectiva actual. Cienc. Tecnol. Aliment. 2000, 3, 39-47. 
204. Rojek-Podgórska, B. EU Legislation in Progress: Review of Medicated feed Legislation. European Parliamentary Research Service (EPRS). 2016. Available online: http:/ / www.europarl.europa.eu/RegData/etudes/BRIE/2016/ 583843/EPRS_BRI\%282016\%29583843_EN.pdf (accessed on 10 July 2018).

205. Kang, H.; Lee, S.; Shin, D.; Jeong, J.; Hong, J.; Rhee, G. Occurrence of veterinary drug residues in farmed fishery products in South Korea. Food Control 2018, 85, 57-65. [CrossRef]

206. Kumar Saxena, S.; Rangasamy, R.; Krishnan, A.; Singh, D.; Uke, S.; Kumar Malekadi, P.; Sengar, A.; Peer Mohamed, D. Simultaneous determination of multi-residue and multi-class antibiotics in aquaculture shrimps by UPLC-MS/MS. Food Chem. 2018, 260, 336-343. [CrossRef] [PubMed]

207. Barreto, F.; Ribeiro, C.; Barcellos Hoft, R.; Dalla Costa, T. A simple and high-throughput method for determination and confirmation of 14 coccidiostats in poultry muscle eggs using liquid chromatography-quadrupole linear ion trap-tandem mass spectrometry (HPLC-QqLIT-MS/MS): Validation according to European Union 2002/657/EC. Talanta 2017, 168, 43-51. [PubMed]

208. World Health Organization. Global Action Plan on Antimicrobial Resistance. WHO Library Cataloguing 2015. Available online: http:/ /www.wpro.who.int/entity/drug_resistance/resources/global_action_plan_eng.pdf (accessed on 18 July 2018).

209. Camargo Valese, A.; Molognoni, L.; Coelho de Souza, N.; Antunes de Sá Ploêncio, L.; Oliveira Costa, A.; Barreto, F. Development, validation and different approaches for the measurement uncertainty of a multi-class veterinary drugs residues LC-MS method for feeds. J. Chromatogr. B 2017, 1053, 48-59. [CrossRef] [PubMed]

210. European Commission. Directive 2001/82/EC of the European Parliament and of the Council of 6 November 2001 on the Community code relating to veterinary medicinal products. Off. J. Eur. Communities 2001, L 311, 1-66. Available online: https:/ / eur-lex.europa.eu/legal-content/EN/TXT/PDF/?uri=CELEX:32001L0082\&from=ES (accessed on 10 July 2018).

211. European Commission. Regulation (EC) No 726/2004 of the European Parliament and of the Council of 31 March 2004 laying down Community procedures for the authorization and supervision of medicinal products for human and veterinary use and establishing a European Medicines Agency. Off. J. Eur. Communities 2004, L 136, 1-33. Available online: https:/ / eur-lex.europa.eu/legal-content/EN/TXT/ PDF/? uri=CELEX:32004R0726\&from=ES (accessed on 10 July 2018).

212. US Food and Drug Administration. Medicated Feeds. Available online: https://www.fda.gov/AnimalVeterinary/ Products/AnimalFoodFeeds/MedicatedFeed/default.htm\#license (accessed on 19 July 2018).

213. Robert, C.; Basseur, P.-Y.; Dubois, M.; Delahaut, P.; Gillard, N. Development and validation of rapid multiresidue and multi-class analysis for antibiotics and anthelmintics in feed by ultra high performance liquid chromatography coupled to tandem mass spectrometry. Food Addit. Contam. Part A 2016, 33, 1312-1323. [CrossRef]

214. Shendy, A.; Al-Ghobashy, M.; Gad Alla, S.; Lotfy, H. Development and validation of a modified QuEChERS protocol coupled to LC-MS/MS for simultaneous determination of multi-class antibiotic residues in honey. Food Chem. 2016, 190, 982-989. [CrossRef] [PubMed]

215. Wang, Y.; Xiao, C.; Guo, J.; Yuan, Y.; Wang, J.; Liu, L.; Yue, T. Development and application of method for the analysis of 9 mycotoxins in maize by HPLC-MS/MS. J. Food Sci. 2013, 78, 1752-1756. [CrossRef]

216. Duelge, K.; Nishshanka, U.; De Alwis, H. An LC-MS/MS method for the determination of antibiotic residues in distillers grains. J. Chromatogr. B Analyt. Technol. Biomed. Life Sci. 2017, 1053, 81-86. [CrossRef]

217. Mohanty, B.; Mahanty, A.; Ganguly, S.; Sankar, T.V.; Chakraborty, K.; Rangasamy, A.; Paul, B.; Sarma, D.; Mathew, S.; Kunnath Asha, K.; et al. Amino acid compositions of 27 food fishes and their importance in clinical nutrition. J. Amino Acids 2014, 2014, 269797. [CrossRef]

218. 218Ribeiro Alvarenga, R.; Borges Rodrigues, P.; de Souza Cantarelli, V.; Gilberto Zangeronimo, M.; da Silva Júnior, J.; da Silva, L.; Moreira dos Santos, L.; Pereira, L. Energy values and chemical composition of spirulina (Spirulina platensis) evaluated with broilers. Rev. Bras. Zootec. 2011, 40, 992-996. [CrossRef]

219. Campanella, L.; Russo, M.V.; Avino, P. Free and total amino acid composition in blue-green algae. Ann. Chim. 2002, 92, 343-352. [PubMed]

220. Abdullah Al-Dhabi, N.; Valan Arasu, M. Quantification of Phytochemical from Commercial Spirulina Products and Their Antioxidant Activities. Evid. Based Complement. Alternat. Med. 2016, 2016, 7631864. 
221. Dziagwa-Becker, M.M.; Ramos, J.M.M.; Topolski, J.K.; Oleszek, W.A. Determination of free amino acids in plants by liquid chromatography coupled to tandem mass spectrometry (LC-MS/MS). BioSci. Trends 2011, 5, 231-238. [CrossRef]

222. Ma, X.; Zhao, D.; Li, X.; Meng, L. Chromatographic method for determination of the free amino acid content of chamomile flowers. Pharmacogn. Mag. 2015, 11, 176-179. [PubMed]

223. Salazar-Villanea, S.; Bruininx, E.M.A.M.; Gruppen, H.; Hendriks, W.H.; Carré, P.; Quinsac, A.; van der Poel, A.F.B. Physical and chemical changes of rapessed meal proteins during toasting and their effects on in vitro digestibility. J. Anim. Sci. Biotechnol. 2016, 7, 62. [CrossRef]

224. Jajić, I.; Krstović, S.; Glamočić, D.; Jakšić, S.; Abramović, B. Validation of an HPLC method for the determination of amino acids in feed. J. Serbian Chem. Soc. 2013, 78, 839-850. [CrossRef]

225. Szkudzińska, K.; Smutniak, H.; Rubaj, J.; Korol, W.; Bielecka, G. Method validation for determination of amino acids in feed by UPLC. Accredit. Qual. Assur. 2018, 22, 247-252. [CrossRef]

226. Desmarais, S.M.; Cava, F.; de Pedro, M.A.; Casey Huang, K. Isolation and Preparation of Bacterial Cell Walls for Compositional Analysis by Ultra Performance Liquid Chromatography. J. Vis. Exp. 2014, 83, e51183. [CrossRef]

227. Kühner, D.; Stahl, M.; Demircioglu, D.D.; Bertsche, U. From cells to muropeptide structures in 24 h: Peptidoglycan mapping by UPLC-MS. Sci. Rep. 2014, 4, 7494. [CrossRef]

228. Marseglia, A.; Sforza, S.; Faccini, A.; Bencivenni, M.; Palla, G.; Caligian, A. Extraction, identification and semi-quantification of oligopeptides in cocoa beans. Food Res. Int. 2014, 63, 382-389. [CrossRef]

229. Prados, I.M.; Marina, M.L.; García, M.C. Isolation and identification by high resolution liquid chromatography tandem mass spectrometry of novel peptides with multifunctional lipid lowering capacity. Food Res. Int. 2018, 111, 77-86. [CrossRef] [PubMed]

230. Holman, B.W.B.; Malau-Aduli, A.E.O. Spirulina as livestock supplement and animal feed. J. Anim. Physiol. Anim. Nutr. 2013, 97, 615-623. [CrossRef] [PubMed]

231. Nurcahya Dewi, E.; Amalia, U.; Mel, M. The effect of Different Treatments to the Amino Acid Contents of Micro Algae Spirulina sp. Aquatic Procedia 2016, 7, 59-65. [CrossRef]

232. Wang, Y.; Shen, K.; Li, P.; Zhou, J.; Chao, Y. Simultaneous determination of 20 underivatized amino acids by high performance liquid chromatography-evaporative light-scattering detection. Se Pu 2011, 29, 908-911. [PubMed]

233. Prinsen, H.C.M.T.; Schiebergen-Bronkhorst, B.G.M.; Roeleveld, M.N.; Jans, J.J.M.; de Sain-van der Velden, M.G.M.; Visser, G.; van Hasselt, P.M.; Verhoeven-Duif, N.M. Rapid quantification of underivatized amino acids in plasma by hydrophilic interaction liquid chromatography (HILIC) coupled with tándem mass-spectrometry. J. Inherit. Metab. Dis. 2016, 39, 651-660. [CrossRef]

234. Masuda, A.; Dohmae, N. Amino acid analysis of sub-picomolar amounts of proteins by pre-column fluorescence derivatization with 6-aminoquinolyl-N-hydroxysuccinimidyl carbamate. Biosc. Trends 2011, 5, 231-238. [CrossRef]

235. Dhillon, M.K.; Kumar, S.; Gujar, G.T. A common HPLC-PDA method for amino acid analysis in insects and plants. Indian J. Exp. Biol. 2014, 52, 73-79.

236. Artavia, G.; Rojas-Bogantes, L.; Granados-Chinchilla, F. Two alternative chromatography methods assisted by the sulfonic acid moiety for the determination of furosine in milk. MethodsX 2018, 5, 639-647. [CrossRef]

237. Dolowy, M.; Pyka, A. Application of TLC, HPLC and GC methods to the study of amino acid and peptide enantiomers: A review. Biomed. Chromatogr. 2013. [CrossRef]

238. Bartolomeo, M.; Maisano, F. Validation of a Reversed-Phase HPLC Method for Quantitative Amino Acid Analysis. J. Biomol. Tech. 2006, 17, 131-137.

239. Zhou, X.; Zhang, J.; Pan, Z.; Li, D. Review of Methods for the Detection and Determination of Malachite Green and Leuco-Malachite Green in Aquaculture. Crit. Rev. Anal. Chem. 2018, 14, 1-20. [CrossRef] [PubMed]

240. Adel, M.; Dadar, M.; Oliveri Conti, G. Antibiotics and malachite green in farmed rainbow trout (Oncorhynchus mykiss) from Iranian markets: A risk assessment. Int. J. Food Prop. 2017, 20, 402-408. [CrossRef]

241. Sudova, E.; Machova, J.; Svobodova, Z.; Vesely, T. Negative effects of malachite green and possibilities of its replacement in the treatment of fish eggs and fish: A review. Vet. Med. 2007, 52, 527-539. [CrossRef]

242. Hidayah, N.; Abu Bakar, F.; Mahyudin, N.A.; Faridah, S.; Nur-Azura, M.S.; Zaman, M.Z. Detection of malachite green and leuco-malachite green in fishery industry. Int. Food Res. J. 2013, 20, 1511-1519. 
243. Xie, J.; Peng, T.; Chen, D.; Zhang, Q.; Wang, G.; Wang, X.; Guo, Q.; Jiang, F.; Chen, D.; Deng, J. Determination of malachite green, crystal violet and their leuco-metabolites in fish by HPLC-VIS detection after immunoaffinity column clean-up. J. Chromatogr. B 2013, 913-914, 123-128. [CrossRef] [PubMed]

244. Chen, G.; Miao, S. HPLC Determination and MS Confirmation of Malachite Green, Gentian Violet, and Their Leuco Metabolite Residues in Channel Catfish Muscle. J. Agric. Food Chem. 2010, 58, 7109-7114. [CrossRef] [PubMed]

245. Wang, Y.; Liao, K.; Huang, X.; Yuan, D. Simultaneous determination of malachite green, crystal violet and their leuco-metabolites in aquaculture water samples using monolithic fiber-based solid-phase microextraction coupled with high performance liquid chromatography. Anal. Methods 2015, 7, 8138. [CrossRef]

246. Bae Lee, J.; Yun Kim, H.; Mi Jang, Y.; Young Song, J.; Min Woo, S.; Sun Park, M.; Sook Lee, H.; Kyu Lee, S.; Kim, M. Determination of malachite green and crystal violet in processed fish products. Food Addit. Contam. Part A 2010, 27, 953-961. [CrossRef]

247. Chengyun, Z.; Jie, W.; Xuefang, D.; Zhimou, G.; Mingyang, L.; Xinmiao, L. Fast analysis of malachite green, leucomalachite green, crystal violet and leucocrystal violet in fish tissue based on a modified QuEChERS procedure. Chin. J. Chromatogr. 2014, 4, 419-425.

248. Turnipseed, S.B.; Andersen, W.C.; Roybal, J.E. Determination and Confirmation of Leucomalachite Green in Salmon using No-Discharge Atmospheric Pressure Chemical Ionization LC-MS. J. AOAC Int. 2005, 88, 1312-1317.

249. Abro, K.; Mahesar, S.A.; Iqbal, S.; Perveen, S. Quantification of malachite green in fish feed utilizing liquid chromatography-tandem mass spectrometry with a monolithic column. Food Addit. Contam. Part A 2014, 31, 827-832. [CrossRef] [PubMed]

250. EFSA. Malachite green in food, EFSA Panel on Contaminants in the Food Chain (CONTAM). EFSA J. 2016, 14, 4530. [CrossRef]

251. Furusawa, N. An isocratic Toxic Chemical-Free Mobile Phase HPLC-PDA analysis of Malachite Green and Leuco-Malachite Green. Chromatography 2014, 1, 75-81. [CrossRef]

252. Bilandžić, N.; Varenina, I.; Solomun Kolanović, B.; Oraić, D.; Zrnčić, S. Malachite green residues in farmed fish in Croatia. Food Control 2012, 26, 393-396. [CrossRef]

253. Barani, A.; Tajik, H. Malachite green residue in farmed fish in north-west part of Iran. Int. J. Food Prop. 2017, 20, S580-S585. [CrossRef]

254. Bedale, W.; Sindelar, J.J.; Milkowski, A.L. Dietary nitrate and nitrite: Benefits, risks, and evolving perceptions. Meat Sci. 2016, 120, 85-92. [CrossRef] [PubMed]

255. Wakida, F.T.; Lerner, D.N. Non-agricultural sources of groundwater nitrate: Review and case study. Water Res. 2005, 39, 3-16. [CrossRef]

256. Deutsche Forschungsgemeinschaft. Nitrate and Nitrite in Diet: An Approach to Assess Benefit and Risk for Human Health; Institut für Lebensmitteltoxikol: Hannover, Germany, 2014; p. 42.

257. Iammarino, M.; Di Taranto, A.; Cristino, M. Monitoring of nitrites and nitrates levels in leafy vegetables (spinach and lettuce): A contribution to risk assessment. J. Sci. Food Agric. 2014, 94, 773-778. [CrossRef]

258. Lundberg, J.O.; Gladwin, M.T.; Ahluwalia, A.; Benjamin, N.; Bryan, N.S.; Butler, A.; Cabrales, P.; Fago, A.; Feelisch, M.; Ford, P.C.; et al. Nitrate and nitrite in biology, nutrition and therapeutics. Nat. Chem. Biol. 2009, 5, 865-869. [CrossRef]

259. Shiva, S. Nitrite: A physiological store of nitric oxide and modulator of mitochondrial function. Redox Biol. 2013, 1, 40-44. [CrossRef]

260. Espejo-Herrera, N.; Gràcia-Lavedan, E.; Boldo, E.; Aragonés, N.; Pérez-Gómez, B.; Pollán, M.; Molina, A.J.; Fernández, T.; Martín, V.; La Vecchia, C.; et al. Colorectal cancer risk and nitrate exposure through drinking water and diet. Int. J. Cancer 2016, 139, 334-346. [CrossRef] [PubMed]

261. Ward, M.H. Too Much of Good Thing? Nitrate from Nitrogen Fertilizers and Cancer. Rev. Environ. Health 2009, 24, 357-363. [CrossRef] [PubMed]

262. European Commission. Regulation (EC) No 1881/2006 of 19 December 2006 setting levels for certain contaminants in foodstuff. Off. J. Eur. Communities 2006, 016.011, 1-35.

263. Brkić, D.; Bošnir, J.; Bevardi, M.; Gross Bošković, A.; Miloš, S.; Lasić, D.; Krivohlavek, A.; Racz, A.; Mojsović-Ćuić, A.; Uršulin Trstenjak, N. Nitrate in leafy green vegetables and estimated intake. Afr. J. Tradit. Complement. Altern. Med. 2017, 14, 31-41. [PubMed] 
264. Pardo, O.; Yusà, V.; Villalba, P.; Perez, J.A. Monitoring programme on nitrate in vegetables and vegetable-based baby foods marketed in the Region of Valencia: Levels and estimated daily intake. Food Addit. Contam. 2010, 27, 478-486. [CrossRef] [PubMed]

265. Quijano, L.; Yusà, V.; Font, G.; McAllister, C.; Torres, C.; Pardo, O. Risk assessment and monitoring programme of nitrates through vegetables in the Region of Valencia (Spain). Food Chem. Toxicol. 2017, 100, 42-49. [CrossRef] [PubMed]

266. Hsu, J.; Arcot, J.; Lee, N.A. Nitrate and nitrite quantification from cured meat and vegetables and their estimated dietary intake in Australians. Food Chem. 2009, 115, 334-339. [CrossRef]

267. Dumitru Croitoru, M. Nitrite and nitrate can be accurately measured in samples of vegetal and animal origin using an HPLC-UV/VIS technique. J. Chromatogr. B 2012, 911, 154-161. [CrossRef]

268. Tsikas, D. Analysis of nitrite and nitrate I biological fluids by assays based on the Griess reaction: Appraisal of the Griess reaction in the L-arginine/nitric oxide area of research. J. Chromatogr. B 2007, 851, 51-70. [CrossRef]

269. Dumitru Croitoru, M.; Fülöp, I.; Miklos, A.; Hosszú, B.; Tátar, V.; Muntean, D. Presence of nitrate and nitrite in vegetables grown for self-consumption. Farmacia 2015, 63, 530-533.

270. Yagoub Abdulkair, B.; Elzupir, A.O.; Alamer, A.S. An Ultrasound Assessed Extraction Combined with Ion-Pair HPLC Method and Risk Assessment of Nitrite and Nitrate in Cured Meat. J. Anal. Methods Chem. 2018, 2018, 1907151. [CrossRef] [PubMed]

271. Chou, S.; Chung, J.; Hwang, D. A High Performance Liquid Chromatography Method for Determining Nitrate and Nitrite Levels in Vegetables. J. Food Drug Anal. 2003, 11, 233-238.

272. Nemade, K.; Fegade, U.; Ingle, S.; Attarde, S. High Performance Liquid Chromatography Method for Determination of Nitrite and Nitrate in Vegetable and Water samples. Int. J. Adv. Sci. Tech. Res. 2014, 4, 238-250.

273. Scheeren, M.B.; Arul, J.; Gariépy, C. Comparison of different method for nitrite and nitrate determination in meat products. In Proceedings of the 59th International Congress of Meat Science and Technology, Izmir, Turkey, 18-23 August 2013.

274. Dos Santos Baião, D.; Conte-Junior, C.; Flosi Paschoalin, V.; Silveira Alvares, T. Quantitative and Comparative Contents of Nitrate and Nitrite in Beta vulgaris L. by Reversed. Phase High-Performance Liquid Chromatography-Fluorescence. Food Anal. Methods 2016, 9, 1002-1008. [CrossRef]

275. Casanova, J.A.; Gross, L.K.; McMullen, S.E.; Schenck, F.J. Use of Greiss reagent containing Vanadium(III) fro post-column derivatization and simultaneous determination of nitrite and nitrate in baby food. J. AOAC Int. 2006, 89, 447-451. [PubMed]

276. Marcus, Y. Thermodynamics of Solvation of Ions. J. Chem. Soc. Faraday Trans. 1991, 87, 2995-2999. [CrossRef]

277. Oruc, H.H.; Akkoc, A.; Uzunoglu, I.; Kennerman, E. Nitrate Poisoning in Horses Associated with Ingestion of Forage and Alfalfa. J. Equine Vet. Sci. 2010, 30, 159-162. [CrossRef]

278. Merino, L.; Örnemark, U.; Toldrá, F. Chapter Three-Analysis of Nitrite and Nitrate in Foods: Overview of Chemical, Regulatory and Analytical Aspects. Adv. Food Nutr. Res. 2017, 81, 65-107. [PubMed]

279. Wang, Q.; Yu, L.; Liu, Y.; Lin, L.; Lu, R.; Zhu, J.; He, L.; Lu, Z. Methods for the detection and determination of nitrite and nitrate: A review. Talanta 2017, 165, 709-720. [CrossRef]

280. O'Neil, C.A.; Schwartz, S.J. Chromatographic analysis of cis/trans carotenoid isomers. J. Chromatogr. 1992, 624, 235-252. [CrossRef]

281. Wilberg, V.C.; Rodriguez-Amaya, D.B. HPLC Quantitation of Major Carotenoids of Fresh and Processed Guava, Mango and Papaya. LWT-Food Sci. Technol. 1995, 28, 474-480. [CrossRef]

282. Zanatta, C.F.; Mercadante, A.Z. Carotenoid composition from the Brazilian tropical fruit camu-camu (Myrciaria dubia). Food Chem. 2007, 101, 1526-1532. [CrossRef]

283. Chen, J.P.; Tai, C.Y.; Chen, B.H. Improved liquid chromatographic method for determination of carotenoids in Taiwanese mango (Mangifera indica L.). J. Chromatogr. A 2004, 29, 261-268. [CrossRef]

284. Inbaraj, B.S.; Chien, J.T.; Chen, B.H. Improved High Performance Liquid Chromatographic Method for Determination of Carotenoids in the Microalga Chlorella pyrenoidosa. J. Chromatogr. A 1102, 1102, 193-199. [CrossRef] [PubMed]

285. McGraw, K.J.; Toomey, M.B. Carotenoid accumulation in the tissues of zebra finches: Predictors of integumentary pigmentation and implications for carotenoid allocation strategies. Physiol. Biochem. Zool. 2010, 83, 97-109. [CrossRef] [PubMed] 
286. Aluç, Y.; Kankılıç, G.B.; Tüzün, I. Determination of carotenoids in two algae species from the saline water of Kapulukaya reservoir by HPLC. J. Liquid Chromatogr. Relat. Technol. 2018, 41, 1-8. [CrossRef]

287. Shih-Chuan, L.; Jau-Tien, L.; Deng-Jye, Y. Determination of cis- and trans- $\alpha$ - and $\beta$-carotenoids in Taiwanese sweet potatoes (Ipomoea batatas (L.) Lam.) harvested at various times. Food Chem. 2009, 116, 605-610.

288. Van Jaarsveld, P.J.; Marais, D.W.; Harmse, E.; Nestel, P.; Rodriguez-Amaya, D.B. Retention of $\beta$-carotene in boiled, mashed orange-fleshed sweet potato. J. Food Compos. Anal. 2006, 19, 321-329. [CrossRef]

289. Huck, C.; Popp, M.; Scherz, H.; Bonn, G.K. Development and Evaluation of a New Method for the Determination of the Carotenoid Content in Selected Vegetables by HPLC and HPLC-MS-MS. J. Chromatogr. Sci. 2000, 38, 441-449. [CrossRef]

290. Lessin, W.J.; Catigani, G.L.; Schwartz, S.J. Quantification of cis-trans Isomers of Provitamin A Carotenoids in Fresh and Processed Fruits and Vegetables. J. Agric. Food Chem. 1997, 45, 3728-3732. [CrossRef]

291. Gayosso-García, L.E.; Yahia, E.M.; González-Aguila, G.A. Identification and quantification of phenols, carotenoids, and vitamin C from papaya (Carica papaya L., cv. Maradol) fruit determined by HPLC-DAD-MS/MS-ESI. Food Res. Int. 2011, 44, 1284-1291. [CrossRef]

292. Schweiggert RFSteingass, C.B.; Esquivel, P.; Carle, R. Chemical and Morphological Characterization of Costa Rican Papaya (Carica papaya L.) Hybrids and Lines with Particular Focus on Their Genuine Carotenoid Profiles. J. Agric. Food Chem. 2012, 60, 2577-2585.

293. Chacón-Ordóñez, T.; Schweiggert, R.M.; Bosy-Westphal, A.; Jiménez, V.M.; Carle, R.; Esquivel, P. Carotenoids and carotenoid esters of orange- and yellow-fleshed mamey sapote (Pouteria sapota (Jacq.) H.E. Moore \& Stearn) fruit and their postprandial absorption in humans. Food Chem. 2017, 221, 673-682. [PubMed]

294. Rojas-Garbanzo, C.; Gleichenhagen, M.; Heller, A.; Esquivel, P.; Schulze-Kaysers, N.; Schieber, A. Carotenoid profile, antioxidant capacity, and chromoplasts of pink guava (Psidium guajava L. Cv. 'Criolla') during fruit ripening. J. Agric. Food Chem. 2017, 65, 3737-3747. [CrossRef] [PubMed]

295. Irias-Mata, A.; Jiménez, V.M.; Steingass, C.B.; Schweiggert, R.M.; Carle, R.; Esquivel, P. Carotenoids and xanthophyll esters of yellow and red nance fruits (Byrsonima crassifolia (L.) Kunth) from Costa Rica. Food Res. Int. 2018, 111, 708-714. [CrossRef] [PubMed]

296. Marutti, L.R.B.; Mercadante, A.Z. Carotenoid esters analysis and occurrence: What do we know so far? Arch. Biochem. Biophys. 2018, 648, 36-43. [CrossRef] [PubMed]

297. Wen, X.; Hempel, J.; Schweiggert, R.M.; Ni, Y.; Carle, R. Carotenoids and carotenoid esters of red and yellow Physalis (Physalis alkekengi L. and P. pubescens L.) fruits and calyces. J. Agric. Food Chem. 2017, 65, 6140-6151. [CrossRef] [PubMed]

298. De Rosso, V.; Mercadante, A. Identification and Quantification of Carotenoids, by HPLC-PDA-MS/MS, from Amazonian Fruits. J. Agric. Food Chem. 2007, 55, 5062-5072. [CrossRef]

299. Ligor, M.; Kováčová, J.; Gadzała-Kopciuch, R.; Studzińska, S.; Bocian, S.; Lehotay, J.; Buszewski, B. Study of RP HPLC Retention Behaviours in Analysis of Carotenoids. Chromatographia 2014, 77, 1047-1057. [CrossRef]

300. Schex, R.; Lieb, V.; Jiménez, V.M.; Esquivel, P.; Schweiggert, R.; Carle, R.; Steingrass, C.B. HPLC-DAD-APCI/ESI-MS ${ }^{n}$ analysis of carotenoids and $\alpha$-tocopherol in Costa Rican Acrocomia aculeata fruits of varying maturity stages. Food Res. Int. 2018, 105, 645-653. [CrossRef]

301. Schweiggert, R.M.; Vargas, E.; Conrad, J.; Hempel, J.; Gras, C.C.; Ziegler, J.U.; Mayer, A.; Jiménez, V.; Esquivel, P.; Carle, R. Carotenoids, carotenoid esters, and anthocyanins of yellow-, orange-, and red-peeled cashew apples (Anacardium occidentale L.). Food Chem. 2016, 200, 274-282. [CrossRef] [PubMed]

302. Chacón-Ordoñez, T.; Esquivel, P.; Jiménez, V.M.; Carle, R.; Schweiggert, R.M. Deposition Form and Bioaccessibility of Keto-Carotenoids from Mamey Sapote (Pouteria sapota), Red Bell Pepper (Capsicum annuum), and Sockeye Salmon (Oncorhynchus nerka) Filet. J. Agric. Food Chem. 2016, 64, 1989-1998. [CrossRef] [PubMed]

303. Dolan, J.W. How Much Can I Inject? Part II: Injecting in Solvents Other than Mobile Phase. LCGC N. Am. 2014, 32, 854-859.

304. Pereira da Costa, M.; Conte-Junior, C.A. Chromatographic methods for the determination of carbohydrates and organic acids in foods of animal origin. Compr. Rev. Food Sci. Food Saf. 2015, 14, 586-600. [CrossRef]

305. De Goeij, S. Quantitative Analysis Methods for Sugars. Master's Thesis, Universiteit van Amsterdam, Amsterdam, The Netherlands, August 2013. 
306. Agius, C.; von Tucher, S.; Poppenberger, B.; Rozhon, W. Quantification of sugars and organic acids in tomato fruits. MethodsX 2018, 5, 2537-2550. [CrossRef] [PubMed]

307. Xu, W.; Liang, L.; Zhu, M. Determination of Sugars in Molasses by HPLC Following Solid-Phase Extraction. Int. J. Food Prop. 2015, 18, 547-557. [CrossRef]

308. Koh, D.-W.; Park, J.-W.; Lim, J.-H.; Yea, M.-J.; Bang, D.-Y. A rapid method for simultaneous quantification of 13 sugars and sugar alcohols in food products by UPLC-ELSD. Food Chem. 2018, 240, 694-700. [CrossRef]

309. Zielinkski, A.A.F.; Braga, C.M.; Demiate, I.M.; Beltrame, F.L.; Nogueira, A.; Wosiaki, G. Development and optimization of a HPLC-RI method for the determination of major sugars in apple juice and evaluation of the effect of the ripening stage. Food Sci. Technol. 2014, 34, 38-43. [CrossRef]

310. Duarte-Delgado, D.; Narváez-Cuenca, C.E.; Restrepo-Sánchez, L.P.; Kushalappa, A.; Mosquera-Vásquez, T. Development and validation of a liquid chromatographic method to quantify sucrose, glucose, and fructose in tubers of Solanum tuberosum Group Phureja. J. Chromatogr. B 2015, 975, 18-23. [CrossRef]

311. Shindo, T.; Sadamasu, Y.; Suzuki, K.; Tanaka, Y.; Togawa, A.; Uematsu, Y. Method of quantitative analysis by HPLC and confirmation by LC-MS of sugar alcohols in foods. Shokuhin Eiseigaku Zasshi 2013, 54, 358-363. [CrossRef]

312. Canesin, R.C.F.S.; Isique, W.D.; Buzetti, S.; Aparecida de Souza, J. Derivation method for determining sorbitol in fruit trees. Am. J. Plant Sci. 2014, 5, 3457-3463. [CrossRef]

313. Hung, W.-T.; Chen, Y.-T.; Wang, S.-H.; Liu, Y.-C.; Yang, W.-B. A new method for aldo-sugar analysis in beverages and dietary foods. Funct. Food Health Dis. 2016, 6, 234-245.

314. Valliydan, B.; Shi, H.; Nguyen, H.T. A simple analytical method for high-throughput screening of major sugars from soybean by normal-phase hplc with evaporative light scattering detection. Chromatogr. Res. Int. 2015, 2015, 757649. [CrossRef]

315. Wieß, K.; Alt, M. Determination of single sugars, including inulin, in plants and feed materials by high-performance liquid chromatography and refraction index detection. Fermentation 2017, 3, 36.

316. Verspreet, J.; Pollet, A.; Cuyvers, S.; Vergauwen, R.; Van den Ende, W.; Delcour, J.A.; Courtin, C.M. A simple and accurate method for determining wheat grain fructan content and average degree of polymerization. J. Agric. Food Chem. 2012, 60, 2102-2107. [CrossRef] [PubMed]

317. Correia, D.M.; Dias, L.G.; Veloso, A.C.A.; Dias, T.; Rocha, I.; Rodrigues, L.R.; Peres, A.M. Dietary sugars analysis: Quantification of fructooligosaccharides during fermentation by HPLC-RI method. Front. Nutr. 2014, 1, 11. [CrossRef]

318. Salazar Murillo, M.M.; Granados-Chinchilla, F. Total starch in animal feeds and silages based on the chromatographic determination of glucose. MethodsX 2018, 5, 83-89. [CrossRef]

319. Bai, W.; Fang, X.; Zhao, W.; Huang, S.; Zhang, H.; Qian, M. Determination of oligosaccharides and monosaccharides in Hakka rice wine by precolumn derivation high-performance liquid chromatography. J. Food Drug Anal. 2015, 23, 645-651. [CrossRef]

320. Madhuri, K.V.; Prabhakar, K.V. Recent trends in the characterization of microbial exopolysaccharides. Orient. J. Chem. 2014, 30, 895-904. [CrossRef]

321. Corradini, C.; Cavazza, A.; Bignardi, C. High-performance anion-exchange chromatography coupled with pulsed electrochemical detection as a powerful tool to evaluate carbohydrates of food interest: Principles and applications. Int. J. Carbohydr. Chem. 2012, 2012, 487564. [CrossRef]

322. Dvořáčková, E.; Šnóblová, M.; Hrdlička, P. Carbohydrate analysis: From sample preparation to HPLC on different stationary phases coupled with evaporative light-scattering detection. J. Sep. Sci. 2014, 37, 323-337. [CrossRef] [PubMed]

323. Rippe, J.M.; Angelopoulos, T.J. Added sugars and risk factors for obesity, diabetes and heart disease. Int. J. Obes. 2016, 40, S22-S27. [CrossRef] [PubMed]

324. Louie, J.C.Y.; Moshtaghian, H.; Boylan, S.; Flood, V.M.; Rangan, A.M.; Barclay, A.W.; Brand-Miller, J.C.; Gill, T.P. A systematic methodology to estimate added sugar content of foods. Eur. J. Clin. Nutr. 2015, 69, 154-161. [CrossRef] [PubMed]

325. Uçar, G.; Balaban, M. Hydrolysis of polysaccharides with $77 \%$ sulfuric acid for quantitative saccharification. Turk. J. Agric. For. 2003, 27, 361-365.

326. Yan, X. High performance liquid chromatography for carbohydrate analysis. In High-Performance Liquid Chromatography (HPLC): Principles, Practices and Procedures; Zhuo, Y., Ed.; Nova Science Publishers: Hauppauge, NY, USA, 2014; ISBN 978-1-62948-854-7. 
327. Thøgersen, R.; Castro-Mejía, J.L.; Sundekilde, U.K.; Hansen, L.H.; Hansen, A.K.; Nielsen, D.S.; Bertram, H.C. Ingestion of an inulin-enriched pork sausage product positively modulates the gut microbiome and metabolome of healthy rats. Mol. Nutr. Food Res. 2018, 13, e1800608. [CrossRef]

328. Szpylka, J.; Thiex, N.; Acevedo, B.; Albizu, A.; Angrish, P.; Austin, S.; Bach Knudsen, K.E.; Barber, C.A.; Berg, D.; Bhandari, S.D.; et al. Standard Method Performance Requirements (SMPRs ${ }^{\circledR}$ ) 2018.002: Fructans in Animal Food (Animal Feed, Pet Food, and Ingredients). J. AOAC Int. 2018, 101, 1283-1284. [CrossRef] [PubMed]

329. Longland, A.C.; Byrd, B.M. Pasture nonstructural carbohydrates and equine laminitis. J. Nut. 2006, 136, 2099S-2102S. [CrossRef]

330. Stöber, P.; Bénet, S.; Hischenhuber, C. Simplified Enzymatic High-Performance Anion Exchange Chromatographic Determination of Total Fructans in Food and Pet Foods-Limitations and Measurement Uncertainty. J. Agric. Food Chem. 2004, 52, 2137-2146. [CrossRef]

331. Rühmann, B.; Schmid, J.; Sieber, V. High throughput exopolysaccharide screening platform: From strain cultivation to monosaccharide composition and carbohydrate fingerprinting in one day. Carbohydr. Polym. 2015, 122, 212-220. [CrossRef]

332. Affonso, R.C.L.; Voytena, A.P.L.; Fanan, S.; Pitz, H.; Coelho, D.S.; Hortmann, A.L.; Pereira, A.; Uarrota, V.G.; Hillmann, M.C.; Varela, L.A.C.; et al. Phytochemical composition, antioxidant activity, and the effect of the aqueous extract of coffee (Coffea arabica L.) bean residual press cake on the skin wound healing. Oxidative Med. Cell. Longev. 2016, 2016, 1923754. [CrossRef]

333. Shao, J.; Cao, W.; Qu, H.; Pan, J.; Gong, X. A novel quality by design approach for developing an HPLC method to analyze herbal extracts: A case study of sugar content analysis. PLoS ONE 2018, 13, e019515. [CrossRef] [PubMed]

334. Swetwiwathana, A.; Visessanguan, W. Potential of bacteriocin-producing lactic acid bacteria for safety improvements of traditional Thai fermented meat and human health. Meat Sci. 2015, 109, 101-105. [CrossRef] [PubMed]

335. Gurtler, J.B.; Mai, T.L. Traditional preservatives: Organic acids. Encycl. Food Microbiol. 2014, 3, 119-130.

336. Anyasi, T.A.; Jideani, A.I.O.; Edokpayi, J.N.; Anokwuru, C.P. Application of Organic Acids in Food Preservation. In Organic Acids, Characteristics, Properties and Synthesis; Vargas, C., Ed.; Nova Sciences Publishers, Inc.: New York, NY, USA, 2016; pp. 1-47. ISBN 9781634859523.

337. Neffe-Skocińska, K.; Sionek, B.; Ścibisz, I.; Kotoźyn-Krajewska, D. Acid contents and the effect of fermentation condition of Kombucha tea beverages on physicochemical, microbiological and sensory properties. CyTA-J. Food 2017, 15. [CrossRef]

338. Nour, V.; Trandafir, I.; Ionica, M.E. HPLC Organic Acid Analysis in Different Citrus Juices under Reversed Phase Conditions. Not. Bot. Hort. Agrobot. Cluj 2010, 38, 44-48.

339. Lobo Roriz, C.; Barros, L.; Carvalho, A.M.; Ferreira, I.C.F.R. HPLC-Profiles of Tocopherols, Sugars, and Organic Acids in Three Medicinal Plants Consumed as Infusions. Int. J. Food Sci. 2014, 2014, 241481. [CrossRef]

340. Scherer, R.; Rybka, A.C.P.; Ballus, C.A.; Dillenburg Meinhart, A.; Texeira Filho, J.; Texeira Godoy, H. Validation of HPLC method for simultaneous determination of main organic acids in fruits and juices. Food Chem. 2012, 135, 150-154. [CrossRef]

341. Llano, T.; Quijorna, N.; Andrés, A.; Coz, A. Sugar, acid and furfural quantification in a sulphite pulp mill: Feedstock, product and hydrolysate analysis by HPLC/RID. Biotechnol. Rep. 2017, 15, 75-83. [CrossRef]

342. Jain, I.; Kumar, V.; Satyanarayana, T. Xylooligosaccharides: An economical prebiotic from agroresidues and their health benefits. Indian J. Exp. Biol. 2015, 53, 131-142.

343. Saleh Zaky, A.; Pensupa, N.; Andrade-Eiroa, Á.; Tucker, G.A.; Du, C. A new HPLC method for simultaneously measuring chloride, sugars, organic acids and alcohols in food samples. J. Food Compos. Anal. 2017, 56, $25-33$. [CrossRef]

344. Ergönül, P.G.; Nergiz, C. Determination of Organic Acids in Olive Fruit by HPLC. Czech J. Food Sci. 2010, $28,202-205$. [CrossRef]

345. Tašev, K.; Stefova, M.; Ivanova-Petropulos, V. HPLC method validation and application for organic acid analysis in wine after solid-phase extraction. Maced. J. Chem. Chem. Eng. 2016, 35. [CrossRef]

346. Mihaljević Žulj, M.; Puhelek, I.; Jagatić Korenika, A.M.; Maslov Bandić, L.; Pavlešić, T.; Jeromel, A. Organic Acid Composition in Croatian Predicate Wines. Agric. Conspec. Sci. 2015, 80, 113-117. 
347. Sánchez-Machado, D.I.; López-Cervantes, J.; Martínez-Cruz, O. Quantification of Organic Acids in Fermented Shrimp Waste by HPLC. Food Technol. Biotechnol. 2008, 46, 456-460.

348. Ke, W.C.; Ding, W.R.; Xu, D.M.; Ding, L.M.; Zhang, P.; Li, F.D.; Guo, X.S. Effects of addition of malic or citric acids on fermentation quality and chemical characteristics of alfalfa silage. J. Dairy Sci. 2017, 100, 1-9. [CrossRef] [PubMed]

349. Fasciano, J.M.; Mansour, F.R.; Danielson, N.D. Ion-Exclusion High-Performance Liquid Chromatography of Aliphatic Organic Acids Using a Surfactant-Modified C18 Column. J. Chromatogr. Sci. 2016, 54, 958-970. [CrossRef]

350. Wang, Y.; Wang, J.; Cheng, W.; Zhao, Z.; Cao, J. HPLC method for the simultaneous quantification of the major organic acids in Angeleno plum fruit. IOP Conf. Ser. Mater. Sci. Eng. 2014, 62, 012035. [CrossRef]

351. Coblentz, W.K.; Akins, M.S. Silage review: Recent advances and future technologies for baled silages. J. Dairy Sci. 2018, 101, 4075-4092. [CrossRef] [PubMed]

352. Khan, N.A.; Yu, P.; Ali, M.; Cone, J.W.; Hendriks, W.H. Nutritive value of maize silage in relation to dairy cow performance and milk quality. J. Sci. Food Agric. 2015, 95, 238-258. [CrossRef]

353. Silva, V.P.; Pereira, O.G.; Leandro, E.S.; Da Silva, K.G.; Ribeiro, K.G.; Mantovani, H.C.; Santos, S.A. Effects of lactic acid bacteria with bacteriocinogenic potential on the fermentation profile and chemical composition of alfalfa silage in tropical conditions. J. Dairy Sci. 2016, 99, 1-8. [CrossRef] [PubMed]

354. Kim, H.J.; Lee, M.J.; Kim, H.J.; Cho, S.K. Development of HPLC-UV method for detection and quantification of eight organic acids in animal feed. J. Chromatogr. Sep. Tech. 2017, 8, 385. [CrossRef]

355. Grune, T.; Lietz, G.; Palou, A.; Ross, A.C.; Stahl, W.; Tang, G.; Thurnham, D.; Yin, S.A.; Biesalski, H.K. $\beta$-Carotene Is an Important Vitamin A Source for Humans. J. Nutr. 2010, 140, 2268S-2285S. [CrossRef] [PubMed]

356. Gilbert, C. What is vitamin A and why do we need it? Community Eye Health 2013, 26, 65. [PubMed]

357. Ding, Z.; Saldeen, T.G.P.; Mathur, P.; Mehta, J.L. Mixed tocopherols are better than alpha-tocopherol as antioxidant as good as statins. Curr. Res. Cardiol. 2016, 3, 128-129. [CrossRef]

358. Alshahrani, F.; Aljohani, N. Vitamin D: Deficiency, Sufficiency and Toxicity. Nutrients 2013, 5, 3605-3616. [CrossRef] [PubMed] 
359. Ortiz-Boyer, F.; Fernandez-Romero, J.M.; Luque de Castro, M.D.; Quesada, J.M. Determination of vitamins $\mathrm{D}_{2}, \mathrm{D}_{3}, \mathrm{~K}_{1}$ and $\mathrm{K}_{3}$ and some hydroxy metabolites of vitamin $\mathrm{D}_{3}$ in plasma using a continuous clean-up-preconcentration procedure coupled on-line with liquid chromatography-UV detection. Analyst 1999, 124, 401-406. [CrossRef] [PubMed]

360. Schwalfenberg, G.K. Vitamins K1 and K2: The emerging group of vitamins required for human health. J. Nutr. Metab. 2017, 345, 229-234. [CrossRef] [PubMed]

361. Harshman, S.G.; Finnan, E.G.; Barger, K.J.; Bailey, R.L.; Haytowitz, D.B.; Gilhooly, C.H.; Booth, S.L. Vegetables and Mixed Dishes Are Top Contributors to Phylloquinone Intake in US Adults: Data from the 2011-2012 NHANES. J. Nutr. 2017, 96, 149-154. [CrossRef]

362. Beulens, J.; Booth, S.; van den Heuvel, E.; Stoecklin, E.; Baka, A.; Vermeer, C. The role of menaquinones (vitamin K2) in human health. Br. J. Nutr. 2013, 110, 1357-1368. [CrossRef]

363. Chavez-Servín, J.; Castellote, A.; Lopez-Sabater, M.C. Simultaneous analysis of Vitamins A and E in infant milk-based formulae by normal-phase high-performance liquid chromatography-diode array detection using a short narrow-bore column. J. Chromatogr. A 2003, 1122, 138-143. [CrossRef]

364. Płonka, J.; Toczek, A.; Tomczyk, V. Multivitamin Analysis of Fruits, Fruit-Vegetable Juices, and Diet Supplements. Food Anal. Methods 2012, 5, 1167-1176. [CrossRef]

365. Sami, R.; Li, Y.; Qi, B.; Wang, S.; Zhang, Q.; Han, F.; Ma, Y.; Jing, J.; Jiang, L. HPLC Analysis of Water-Soluble Vitamins (B2, B3, B6, B12, and C) and Fat-Soluble Vitamins (E, K, D, A, and $\beta$-Carotene) of Okra (Abelmoschus esculentus). J. Chem. 2014, 2014, 831357. [CrossRef]

366. Xue, X.; You, J.; He, P. Simultaneous Determination of Five Fat-Soluble Vitamins in Feed by High-Performance Liquid Chromatography Following Solid-Phase Extraction. J. Chromatogr. Sci. 2012, 46, 345-350. [CrossRef]

367. Qian, H.; Sheng, M. Simultaneous determination of fat-soluble vitamins A, D and E and pro-vitamin D2 in animal feeds by one-step extraction and high-performance liquid chromatography analysis. J. Chromatogr. A 1998, 825, 127-133. [CrossRef]

368. Lee, H.; Kwak, B.; Ahn, J.; Jeong, S.; Shim, S.; Kim, K.; Yoon, T.; Leem, D.; Jeong, J. Simultaneous Determination of Vitamin A and E in Infant Formula by HPLC with Photodiode Array Detection. Korean J. Food Sci. Anim. Resour. 2011, 31, 191-199. [CrossRef]

369. Lim, H.; Woo, S.; Sig Kim, H.; Jong, S.; Lee, J. Comparison of extraction methods for determining tocopherols in soybeans. Eur. J. Lipid Sci. Technol. 2007, 109, 1124-1127. [CrossRef]

370. Odes, S.; Hisil, Y. Analysis of vitamin A in eggs by high pressure liquid chromatography. Die Nahr. 1991, 35, $391-394$.

371. Reynolds, S.; Judd, H. Rapid procedure for the determination of vitamins A and D in fortified skimmed milk powder using high-performance liquid chromatography. Analyst 1989, 109, 489-492. [CrossRef]

372. Turner, C.; Persson, M.; Mathiasson, L.; Adlercreutz, P.; King, J.W. Lipase-catalyzed reactions in organic and supercritical solvents: Application to fat-soluble vitamin determination in milk powder and infant formula. Enzym. Microb. Technol. 2001, 29, 111-121. [CrossRef]

373. Jedlička, A.; Klimeš, J. Determination of Water- and Fat-Soluble Vitamins in Different Matrices Using High-Performance Liquid Chromatography. Chem. Papers 2005, 59, 202-222. [CrossRef]

374. Rupérez, F.J.; Martín, D.; Herrera, E.; Barbas, C. Chromatographic analysis of alpha-tocopherol and related compounds in various matrices. J. Chromatogr. A 2001, 935, 45-69. [CrossRef]

375. Stefanov, I.; Vlaeminck, B.; Fievez, V. A novel procedure for routine milk fat extraction based on dichloromethane. J. Food Compos. Anal. 2010, 23, 852-855. [CrossRef]

376. Hung, G.W.C. Determination of Vitamins D2 and D3 in Feedingstuffs by High Performance Liquid Chromatography. J. Liquid Chromatogr. 1988, 11, 953-969. [CrossRef]

377. Lee, S.; Morrisa, Y.; Grossa, L.; Portera, F.; Ortiz-Colona, F.; Farrowa, J.; Waqara, A.; Phifera, E.; Kerdahia, K. Development and Single-Lab Validation of an UHPLC-APCI-MS/MS Method for Vitamin K1 in Infant Formulas and Other Nutritional Formulas. J. Regul. Sci. 2015, 2, 27-35.

378. Wagner, D.; Rousseau, D.; Sidhom, G.; Pouliot MAudet, T.; Vieth, R. Vitamin D3 Fortification, Quantification, and Long-Term Stability in Cheddar and Low-Fat Cheeses. J. Agric. Food Chem. 2008, 56, 7964-7969. [CrossRef]

379. Kienen, V.; Costa, W.; Visentainer, J.; Souza, N.; Oliveira, C. Development of a green chromatographic method for determination of fat-soluble vitamins in food and pharmaceutical supplement. Talanta 2008, 75, 141-146. [CrossRef] [PubMed] 
380. Gomis, D.B.; Fernández, M.P.; Gutiérrez, M.D. Simultaneous determination of fat-soluble vitamins and provitamins in milk by microcolumn liquid chromatography. J. Chromatogr. A 2000, 891, 109-114. [CrossRef]

381. Koivu, T.; Piironen, V.; Henttonen, S.; Mattila, P. Determination of Phylloquinone in Vegetables, Fruits, and Berries by High-Performance Liquid Chromatography with Electrochemical Detection. J. Chromatogr. A 1997, 45, 4644-4649. [CrossRef]

382. Shammugasamy, B.; Ramakrishnan, Y.; Ghazali, H.; Muhammad, K. Tocopherol and tocotrienol contents of different varieties of rice in Malaysia. J. Sci. Food Agric. 2015, 95, 672-678. [CrossRef]

383. Kim, H.O. Development of an ion-pairing reagent and HPLC-UV method for the detection and quantification of six water-soluble vitamins in animal feed. Int. J. Anal. Chem. 2016, 2016, 8357358. [CrossRef]

384. Midttun, Ø.; McCann, A.; Aarseth, O.; Kokeide, M.; Kvalheim, G.; Meyer, K.; Ueland, P.M. Combined measurement of 6 fat-soluble vitamins and 26 water-soluble functional vitamin markers and amino acids in $50 \mu \mathrm{L}$ of serum or plasma by high-throughput mass spectrometry. Anal. Chem. 2016, 88, 10427-10436. [CrossRef] [PubMed]

385. Kakitani, A.; Inoue, T.; Matsumoto, K.; Watanabe, J.; Nagatomi, Y.; Mochizuki, N. Simultaneous determination of water-soluble vitamins in beverages and dietary supplements by LC-MS/MS. Food Addit. Contam. Part A 2014, 31, 1939-1948. [CrossRef] [PubMed]

386. Zhang, Y.; Zhou, W.-E.; Yan, J.-Q.; Liu, M.; Zhou, Y.; Shen, X.; Ma, Y.-L.; Feng, X.-S.; Yang, J.; Li, G.-H. A Review of the Extraction and Determination Methods of Thirteen Essential Vitamins to the Human Body: An Update from 2010. Molecules 2018, 23, 1484. [CrossRef]

387. Abano, E.E.; Dadzie, R.G. Simultaneous detection of water-soluble vitamins using the High Performance Liquid Chromatography (HPLC)—A review. Croat. J. Food Sci. Technol. 2014, 6, 116-123. [CrossRef]

(C) 2018 by the authors. Licensee MDPI, Basel, Switzerland. This article is an open access article distributed under the terms and conditions of the Creative Commons Attribution (CC BY) license (http:/ / creativecommons.org/licenses/by/4.0/). 